\title{
Republic of Tajikistan: Selected Issues and Statistical Appendix
}

This Selected Issues and Statistical Appendix paper for the Republic of Tajikistan was prepared by a staff team of the International Monetary Fund as background documentation for the periodic consultation with the member country. It is based on the information available at the time it was completed on March 4, 2005. The views expressed in this document are those of the staff team and do not necessarily reflect the views of the government of the Republic of Tajikistan or the Executive Board of the IMF.

The policy of publication of staff reports and other documents by the IMF allows for the deletion of market-sensitive information.

To assist the IMF in evaluating the publication policy, reader comments are invited and may be sent by e-mail to publicationpolicy@imf.org.

Copies of this report are available to the public from

International Monetary Fund • Publication Services

700 19th Street, N.W. • Washington, D.C. 20431

Telephone: (202) 6237430 • Telefax: (202) 6237201

E-mail: publications@imf.org • Internet: http://www.imf.org

Price: $\$ 15.00$ a copy

\section{International Monetary Fund}

Washington, D.C. 



\section{INTERNATIONAL MONETARY FUND}

\section{REPUBLIC OF TAJIKISTAN}

\section{Selected Issues and Statistical Appendix}

Prepared by Francis Kumah, John Matovu, Peter Winglee, Roman Zytek (all MCD), Alexei Kireyev (PDR), Felix Fischer (MFD), and David Coady (FAD)

Approved by Middle East and Central Asia Department

March 4, 2005

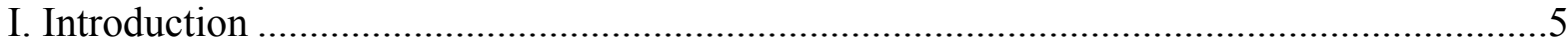

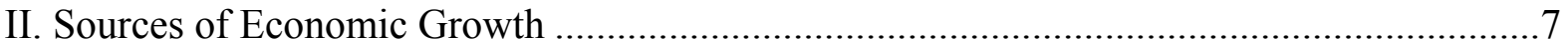

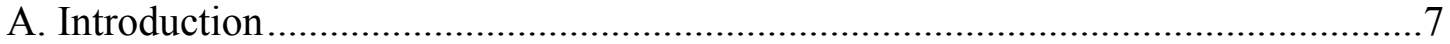

B. Real GDP Growth Developments in Tajikistan and Other CIS Countries ................8

C. Sources of Aggregate and Sectoral Growth ...........................................................

D. Cross-Country Comparisons ………………………......................................13

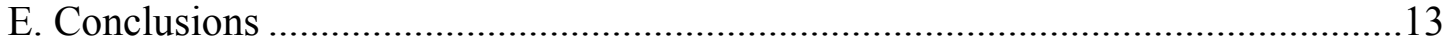

III. Main Elements of the Revised Tax Code ………………..........................................15

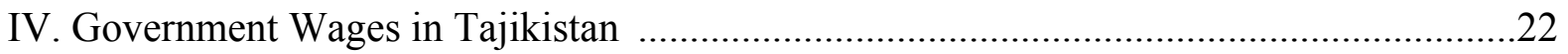

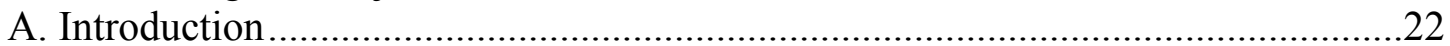

B. Recent Trends in Government Wages and Employment ......................................22

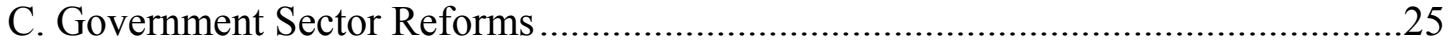

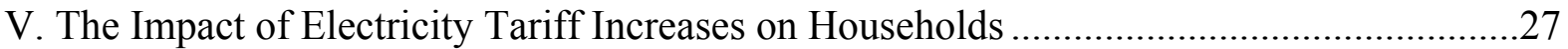

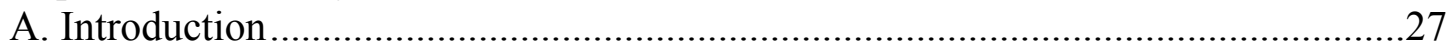

B. The Impact of Tariff Structure Reforms on Households..........................................27

C. The Energy Compensation Mechanism ...............................................................29

D. Concluding Remarks......................................................................................

Table 1: Distribution of Electricity Tariff Reform Burden...........................................32

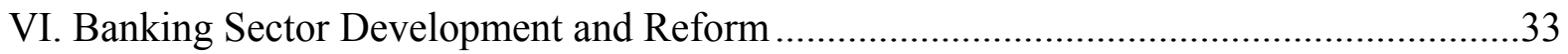

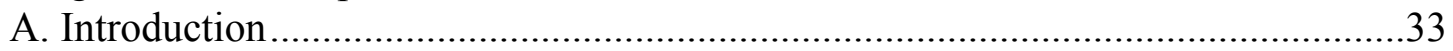

B. Overview of the Banking Sector ..........................................................................34

C. Reforms to Deepen the Banking Sector ...............................................................40 


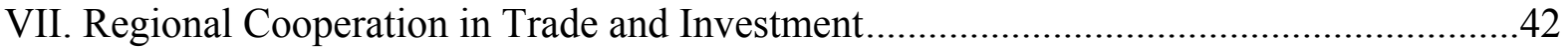

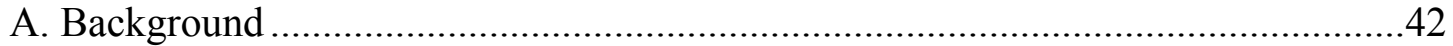

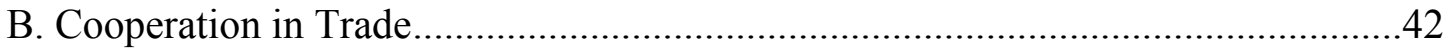

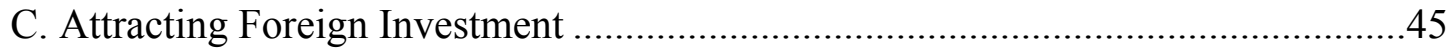

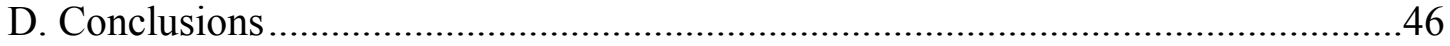

Annex: Evolution of the Trade Regime ..............................................................49

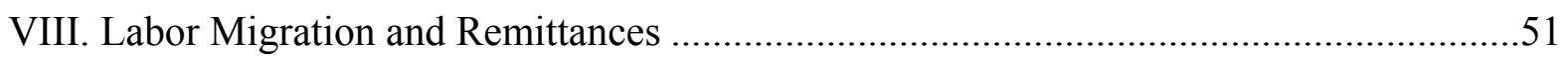

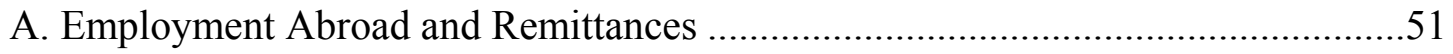

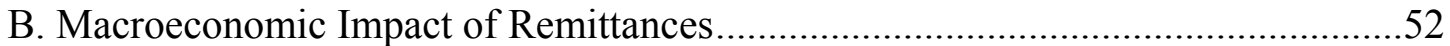

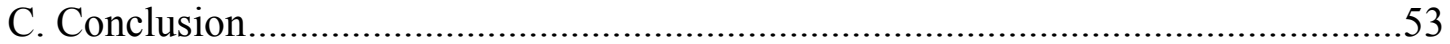

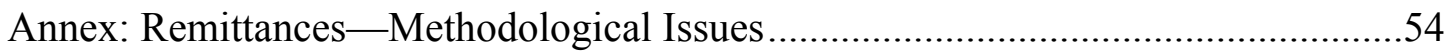

IX. External Public Debt Developments and Sustainability .............................................56

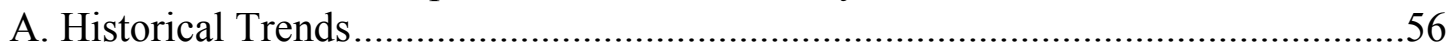

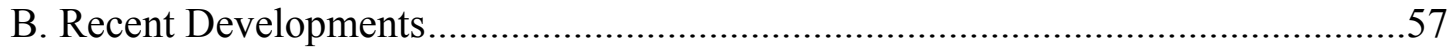

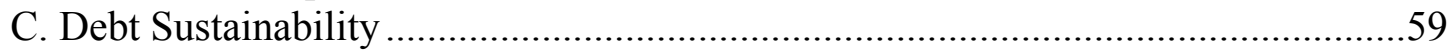

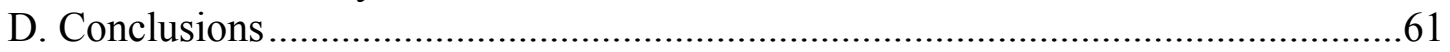

Tables

1. Sensitivity Analyses for Key Indicators of Public External Debt, 2002-23 .............62

2. Government and Government-Guaranteed Sector Debt

Sustainability Framework, Baseline Scenario, 2002-23 .......................................63

3. Sensitivity Analyses for Key Indicators of Public External Debt, 20023-23 ............64

4. Sensitivity Analyses for Key Indicators of Government and

Government-Guaranteed Debt, 2003-23

Figures

1. Indicators of Public External Debt Under Alternative Scenarios, 2003-23 ..............66

2. Indicators of Government and Government-Guaranteed Debt Under

Alternative Scenarios, 2003-23

Statistical Appendix

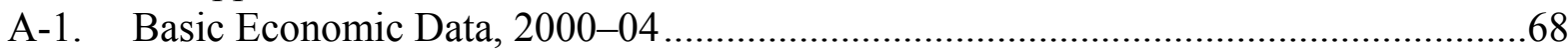

A-2. Nominal and Real GDP, 2000-04 ....................................................................69

A-3. Nominal GDP by Sector of Origin, 2000-04....................................................70

A-4. Production and Yields of Major Agricultural Crops, 2000-04 ...............................71

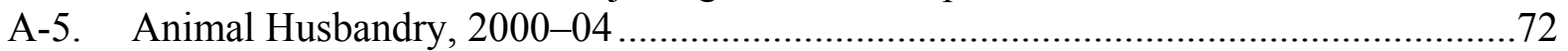

A-6. Agricultural Production by Type of Farm, 2000-04 ................................................73

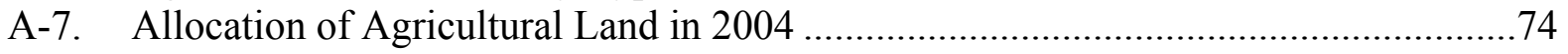

A-8. Industrial Output by Sector at Constant Prices, 2000-04 ......................................75

A-9. Selected Indicators of Industrial Production, 2000-04 ............................................76 
A-10. Electricity Output, Trade and Consumption, 2002-04 ….....................................77

A-11. Labor Resources and Employment, 2000-04 .....................................................78

A-12. Registered Unemployment, 2000-04............................................................ 79

A-13. Employment by Sector of Economy, 2000-04 ..................................................80

A-14. Sectoral Output, Employment and Productivity, 2000-03 .....................................81

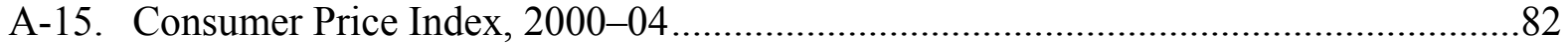

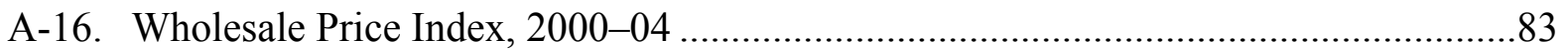

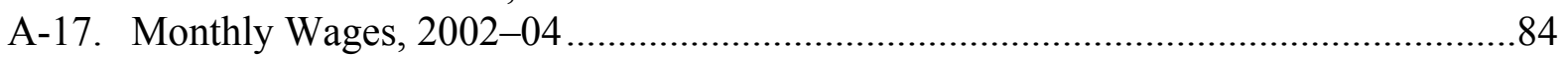

A-18. Average Monthly Wages by Sector, 2000-04 ....................................................85

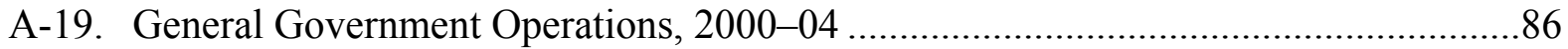

A-20. State Budget by Functional Classification of Expenditures, 2000-04 ......................87

A-21. Operations of the Consolidated General Government, 2000-04 ..............................88

A-22. Accounts of the National Bank of Tajikistan, 2000-04........................................89

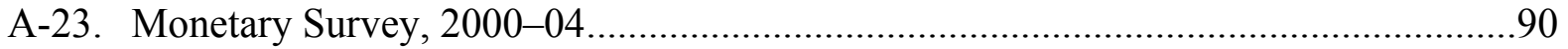

A-24. Credit to the Economy from Commercials Banks, 2002-04 ....................................91

A-25. Average Annual Interest Rates, 2000-04 .............................................................92

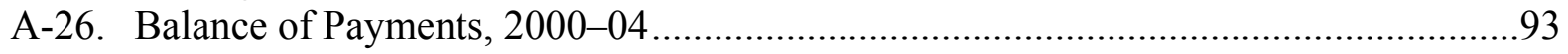

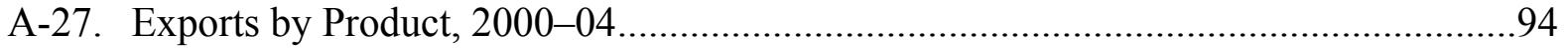

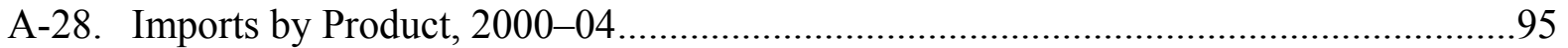

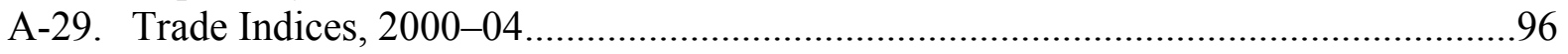

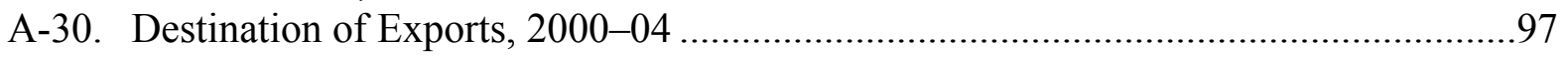

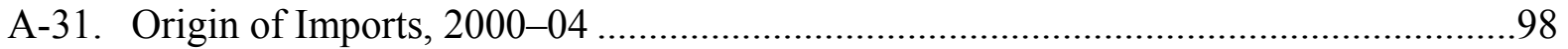

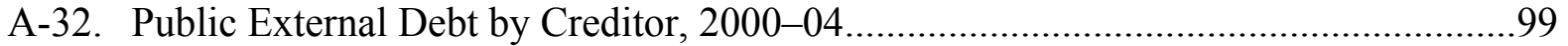

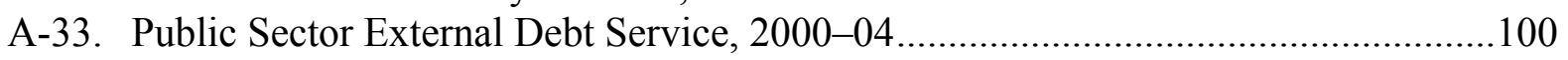

A-34. Exchange Rates and U.S. Dollar Wages, 2000-04 ..............................................101 


\section{LIST OF ACRONYMS}

\begin{tabular}{|c|c|}
\hline AIB & Agroinvestbank \\
\hline $\mathrm{AsDB}$ & Asian Development Bank \\
\hline BRO & Baltics, Russia, and other former Soviet Union countries \\
\hline CIS & Commonwealth of Independent States \\
\hline CIS-7 & $\begin{array}{l}\text { Armenia, Azerbaijan, Georgia, Kyrgyz Republic, Moldova, Tajikistan, } \\
\text { Uzbekistan }\end{array}$ \\
\hline CRT & Cost recovery tariff \\
\hline DSA & Debt sustainability analysis \\
\hline EAEC & Euro-Asian Economic Community \\
\hline EBRD & European Bank for Reconstruction and Development \\
\hline ECM & Energy Compensation Mechanism \\
\hline FAD & IMF Fiscal Affairs Department \\
\hline FDI & Foreign direct investment \\
\hline FSI & Financial soundness indicator \\
\hline GDP & Gross domestic product \\
\hline GGG & Government and government-guaranteed \\
\hline GNDI & Gross national disposable income \\
\hline HIPC & Heavily indebted poor countries \\
\hline IAS & International Accounting Standards \\
\hline IFC & International Finance Corporation \\
\hline IFRS & International Financial Reporting Standards \\
\hline IOM & International Organization of Migration \\
\hline MOF & Ministry of Finance \\
\hline MOET & Ministry of Economy and Trade \\
\hline NBT & National Bank of Tajikistan \\
\hline NFA & Net foreign assets \\
\hline NIR & Net international reserves \\
\hline NPL & Nonperforming loan \\
\hline NPV & Net present value \\
\hline PIP & Public Investment Program \\
\hline PRGF & Poverty Reduction and Growth Facility \\
\hline PSIA & Poverty and social impact analysis \\
\hline SM & Somoni \\
\hline SME & Small- and medium-size enterprises \\
\hline SOE & State-owned enterprises \\
\hline TadAZ & Tajik Aluminum Plant \\
\hline TFP & Total factor productivity \\
\hline UNESCO & United Nations Educational, Scientific, and Cultural Organization \\
\hline VAT & Value-added tax \\
\hline WTO & World Trade Organization \\
\hline
\end{tabular}




\section{INTRODUCTION}

1. Tajikistan has made substantial progress in its transition to a fully fledged market economy over the past two years. Growth has continued to average 10 percent per year, inflation was sharply reduced to about 5 percent by end-2004, the exchange rate has been relatively stable, monetary policy has been strengthened, and the budget balance (excluding the foreign funded public investment program) has recorded surpluses. In addition, regional ties have been strengthened, enabling greater labor mobility, more trading opportunities, and better investment prospects. Compared to four years ago, strong growth, a prudent borrowing policy, and favorable debt restructuring have reduced the stock of public external debt from 131 percent of GDP in 2000 to 40 percent in 2004, an impressive achievement. This volume of selected issues looks at some elements of Tajikistan's recent and prospective performance.

2. Chapter II analyzes the sources of recent growth. It concludes that economic growth has been mainly driven by the services sector and a surge in remittances that have been mainly used for private consumption and small scale private investment. While the early years of the transition to a market economy were characterized by a significant drop in total factor productivity (TFP), since 1998 the economy's rebound is mostly attributable to increases in TFP. In particular, the agricultural and service sectors have achieved a significant rebound in output with relatively modest levels of new capital and labor, reflecting the benefits of reform and stability.

3. The next three chapters look at specific fiscal issues. Chapter III summarizes the recently introduced revisions to the Tax Code, which are an evolutionary step in simplifying the tax system and setting the base for better revenue administration. Chapter IV looks at the level of government wages in relation to the rest of the Tajik economy and other comparable countries in light of the pressure on the government to grant a large increase in wages. Chapter IV examines the likely impact on households of increasing electricity prices to cost recovery levels. It shows that the overall impact on consumers would be manageable, especially if phased in over 5 years, and that a cash payment system has important advantages in targeting measures to reduce the impact on the poor.

4. Chapter VI reviews the measures adopted over the past 2-3 years to strengthen the banking system but notes that the system is still very small in relation to the economy and that further measures are needed for it to support private sector development.

\section{Tajikistan's recent progress at reestablishing regional ties has benefited trade and investment (discussed in Chapter VII) and labor mobility and workers' remittances (discussed in Chapter VIII). Progress in these areas has been a very important factor behind the recovery in output; and further reforms and improvements in bilateral relations will greatly improve Tajikistan's growth prospects. In the investment area, regional linkages are spurring development of additional hydro-electric power projects which could be an important source of growth and budget revenue.}


6. Finally, Chapter IX presents the debt sustainability analysis (DSA) and discusses recent developments in external debt arrangements, including the debt agreement with the Russian Federation. The DSA shows that, even with slightly higher concessional borrowing than in the recent past, under a baseline scenario Tajikistan's external debt profile will remain sustainable. However, given the historical volatility, continued prudence in debt management would be required to ensure this result. 


\section{SOURCES OF ECONOMIC GROWTH ${ }^{1}$}

This chapter analyzes the sources of growth in Tajikistan in 1995-2004. The early years of transition were characterized by a significant drop in total factor productivity (TFP). Since 1998, growth resumed and TFP has increased due to the benefits of stability and reforms. While the agricultural sector has rebounded, industrial production is still way below its historical level. Nevertheless, continued remittances from migrants and measures to support private sector investment are expected to sustain the current high growth rates.

\section{A. Introduction}

1. The early years of transition from a command to a market-based economy in Tajikistan witnessed a considerable decline in output. ${ }^{2}$ Similar to other CIS countries, the contraction has been attributed to a variety of causes, including the dislocation of traditional domestic and international links, and cut-off of transfers from the center. ${ }^{3}$ However, growth resumed by 1998, averaging about 10 percent a year during the period 2000-2004.

2. This paper analyzes the sources of growth from 1990 to 2004 by assessing the contribution of capital, labor, and technological progress, both at the aggregate and sectoral levels. An important objective in examining Tajikistan's recent growth performance is to determine whether the growth process has been intensive or extensive, where intensive growth denotes efficiency-driven growth and extensive growth is achieved by employing more factor inputs.

3. The results of the growth accounting exercise demonstrate that starting in 1998, overall TFP growth resumed for the first time since the breakup of the Soviet Union, and has averaged about 7 percent per year. At a sectoral level, significant increases in TFP have been realized in agriculture and industry, averaging 3 and 8 percent a year, respectively. On the growth outlook, assuming that TFP growth is maintained at current levels, and the forthcoming investments (both public and private) are realized, this would result into sustaining the current growth rates.

4. The remainder of this paper is organized as follows. Section B briefly discusses the recent growth process in Tajikistan compared to other CIS countries; section C analyzes the

\footnotetext{
${ }^{1}$ Prepared by John M. Matovu.

${ }^{2}$ These results in this paper should be interpreted with caution due to data deficiencies. Its documented that part of the falling activity was due to the incentive to report the under fulfillment of plan targets to avoid the scrutiny of tax and other authorities (Koen, 1994).

${ }^{3}$ For an empirical cross-country study, see for instance Berg et al. (1999) and Havrylyshyn et al (2000). This paper focuses on changes in inputs and the evolution of productivity.
} 
sources of aggregate and sectoral growth; and section D provides a cross-country comparison of TFP and marginal productivity of capital. Lastly, Section E presents some conclusions.

\section{B. Real GDP Growth Developments in Tajikistan and Other CIS Countries}

5. Tajikistan experienced a drastic decline in output - averaging 20 percent a year during 1990-1994 (Table 1). The cumulative decline in real output during the same period was 69 percent. While all other CIS countries were undergoing recovery during 1995-1999, Tajikistan's output continued to contract, declining by about 7 percent due to the civil war. By the end of the $1990 \mathrm{~s}$, the country began to show positive growth rates averaging 10 percent a year in 2000-2004 (the CIS-7 average growth was 7 percent). Although much of the growth in Tajikistan during this period is based on the recovery of traditional exports (cotton and aluminum), there are signs that new sectors, especially services, are also expanding. Despite these positive developments, output in 2004 was only about 68 percent of its 1990 level.

Table 1: Real GDP Growth in the CIS-7 Countries, 1990-2004 1/

(In percent)

\begin{tabular}{|c|c|c|c|c|c|c|c|}
\hline & \multicolumn{3}{|c|}{ Average } & \multicolumn{3}{|c|}{ Cumulative Growth } & $\frac{\text { Recovered GDP }}{(1990-2004)}$ \\
\hline Armenia & -15.2 & 5.3 & 9.9 & -63.2 & 29.7 & 59.9 & 78.0 \\
\hline Azerbaijan & -15.6 & 2.5 & 10.4 & -58.1 & 11.7 & 63.8 & 86.7 \\
\hline Georgia & -24.1 & 5.9 & 6.3 & -76.6 & 32.8 & 35.7 & 49.6 \\
\hline Kyrgyz Republic & -11.4 & 3.4 & 4.6 & -45.9 & 17.4 & 24.9 & 81.2 \\
\hline Moldova & -17.3 & -5.9 & 5.5 & -64.1 & -26.8 & 30.3 & 35.1 \\
\hline Tajikistan & -20.2 & -1.2 & 9.6 & -68.9 & -7.1 & 57.8 & 67.7 \\
\hline Uzbekistan & -2.8 & 1.7 & 2.9 & -13.6 & 9.0 & 15.2 & 103.9 \\
\hline CIS (Incl. Tajikistan) & -15.2 & 1.7 & 7.0 & -57.2 & 8.4 & 40.3 & $\ldots$ \\
\hline CIS (Excl. Tajikistan) & -14.4 & 2.2 & 6.6 & -55.2 & 11.1 & 37.5 & $\ldots$ \\
\hline
\end{tabular}

Source: World Economic Outlook (IMF, 2003)

$1 /$ The 2004 growth rates are preliminary.

\section{While Tajikistan's real GDP has rebounded, some sectors (particularly} industry) have not fully recovered to their pre-transition production levels. The sectoral contribution of industry and agriculture started declining in 1995, and has continued to be substituted by services, which contribute 35 percent of GDP. The changes in the sectoral composition of GDP are mainly explained by the stagnation of both the agricultural and industrial sectors compared to their pre-transition production levels.

7. Recovery for most of the agricultural crops production to their pre-transition levels has been achieved (Figure 1a). However, cumulatively, cotton production fell by 
more than 31 percent during the period 1990-2004. Likewise, output of other crops like corn, vegetables and fruits is still way below their maximum potential.

8. The fall in production is even more pronounced in industry, where output fell by over 60 percent (Figure 1b). The downward trend of aluminum production bottomed out in 1997, but the current level of production is 70 percent of the 1990 level. Aluminum contributes more than 40 percent of the value added in the manufacturing sector and further increases in capacity utilization could lead to higher growth in the sector. For most of the other manufactured products (cement, fertilizers, caustic soda and cotton fabrics), production levels remain low.
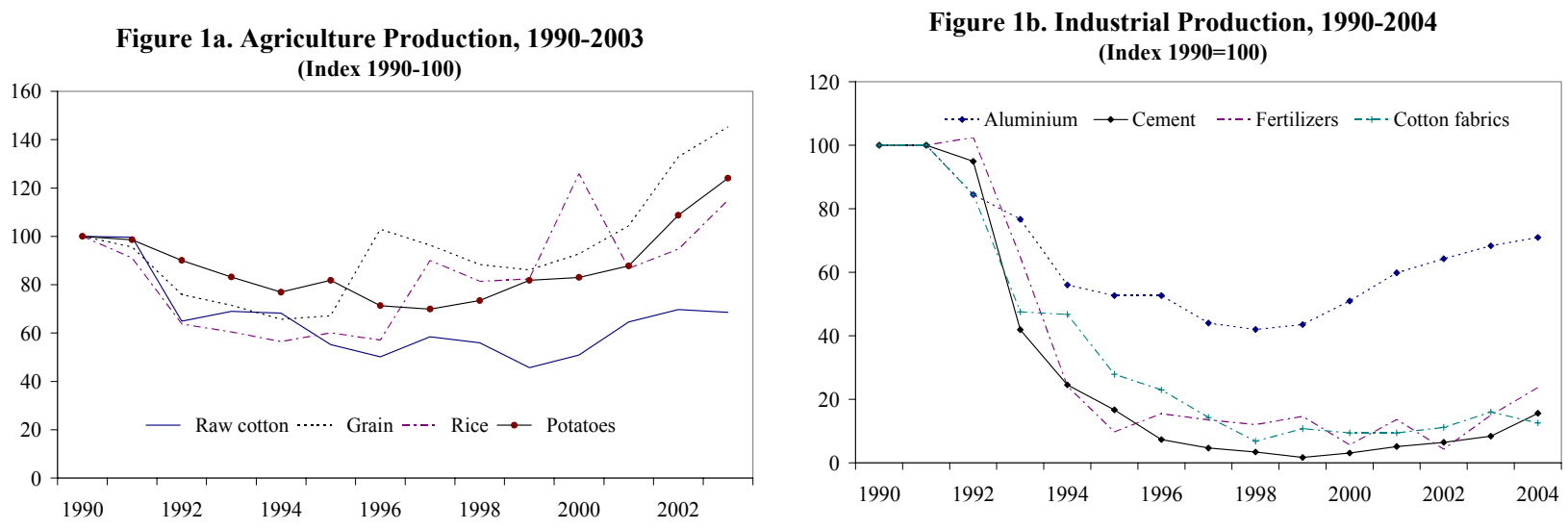

\section{Sources of Aggregate and Sectoral Growth}

9. TFP contracted sharply during the transition. The average annual growth rates of real GDP, capital, labor, and TFP for the different periods are summarized in Table 2. The drop in TFP was particularly pronounced during the conflict years. Negative growth rates of TFP affected all sectors, especially manufacturing and agriculture. Tajikistan sustained high economic growth during the period 2000-2004, averaging 10 percent per annum. For the most part growth was driven by improvements in the use of factors of production, averaging 7 percent a year, and an increase in labor input. While it is widely accepted that growth in services during the past decade has been remarkable for all CIS countries, this sector is not adequately analyzed in this section due to data limitations.

10. The rapid deterioration of the manufacturing sector between 1990-95 can be attributed to several factors. First, there was a significant decline in the demand for the products following the break up of the Soviet Union. As a result, industrial enterprises shed labor. Moreover, investments were too low to maintain the obsolete capital stock and keep up with depreciation. ${ }^{4}$ While the production function used does not capture vintage effects, the

\footnotetext{
${ }^{4}$ The proportion of uncompleted construction projects and uninstalled equipment rose significantly during this period.
} 
efficiency loses associated with increasing capital obsolescence are reflected in the declining TFP growth estimates. Subsequently, output in the manufacturing sector rebounded due to moderate growth in labor and TFP growth during the period $2001-04 .^{5}$

Table 2: Growth Rate of Output, Capital, Labor and TFP

\begin{tabular}{|c|c|c|c|c|c|}
\hline & $1981-85$ & $1986-90$ & $1991-95$ & 1996-00 & 2001-04 \\
\hline & \multicolumn{5}{|c|}{ Total } \\
\hline Capital & 4.6 & 2.9 & 0.2 & -0.1 & 1.1 \\
\hline Labor & 3.1 & 2.9 & -0.9 & -1.1 & 3.0 \\
\hline TFP & -2.4 & -1.6 & -15.5 & 1.3 & 7.2 \\
\hline \multirow[t]{2}{*}{ Output } & 1.2 & 1.3 & -16.1 & 0.5 & 9.7 \\
\hline & \multicolumn{5}{|c|}{ Agriculture } \\
\hline Capital & 4.3 & 1.7 & -2.4 & -5.2 & -3.2 \\
\hline Labor & 3.6 & 2.9 & 5.7 & 0.9 & 1.8 \\
\hline TFP & -3.7 & -5.0 & -26.3 & 2.4 & 7.1 \\
\hline \multirow[t]{2}{*}{ Output } & 0.0 & -2.4 & -23.1 & 1.5 & 3.6 \\
\hline & \multicolumn{5}{|c|}{ Industry } \\
\hline Capital & 5.0 & 2.0 & 1.7 & 0.5 & -0.9 \\
\hline Labor & 3.1 & 1.6 & -6.7 & -7.9 & 5.3 \\
\hline TFP & -1.4 & 0.9 & -8.1 & 4.8 & 8.1 \\
\hline \multirow[t]{2}{*}{ Output } & 2.2 & 2.6 & -12.3 & -0.5 & 11.5 \\
\hline & \multicolumn{5}{|c|}{ Construction } \\
\hline Capital & 6.7 & 6.3 & -2.6 & -3.8 & -4.2 \\
\hline Labor & 2.5 & 6.7 & -12.6 & -14.7 & -13.4 \\
\hline TFP & -3.9 & -8.7 & -8.1 & 6.7 & 16.0 \\
\hline Output & -0.1 & -2.1 & -17.7 & -4.7 & 5.0 \\
\hline
\end{tabular}

Sources: Tajik authorities and Fund staff estimates.

11. Regarding the agricultural sector, the growth accounting framework shows that, following a disappointing performance in the 1990s, the improvement in TFP from 1999 onwards has been encouraging.

\section{To test for the robustness of these computations, alternative calculations are} presented based on productivity of factor inputs. TFP has its limitations as a measure of productivity and should be interpreted with care, particularly as it is not directly observable and must be calculated as a residual after relevant values of output and factor inputs have

\footnotetext{
${ }^{5}$ It is difficult to measure value added in the services sector.
} 
been estimated. The marginal productivity of both capital and labor (an alternative measure of efficiency) declined significantly at the start of the transition (Figure 2). However, for the past five years, these marginal productivities have been increasing suggesting more efficient use of factor inputs. Capital and labor productivities are measured as GDP/K and GDP/L, respectively.

Figure 2. Factor and Marginal Productivity
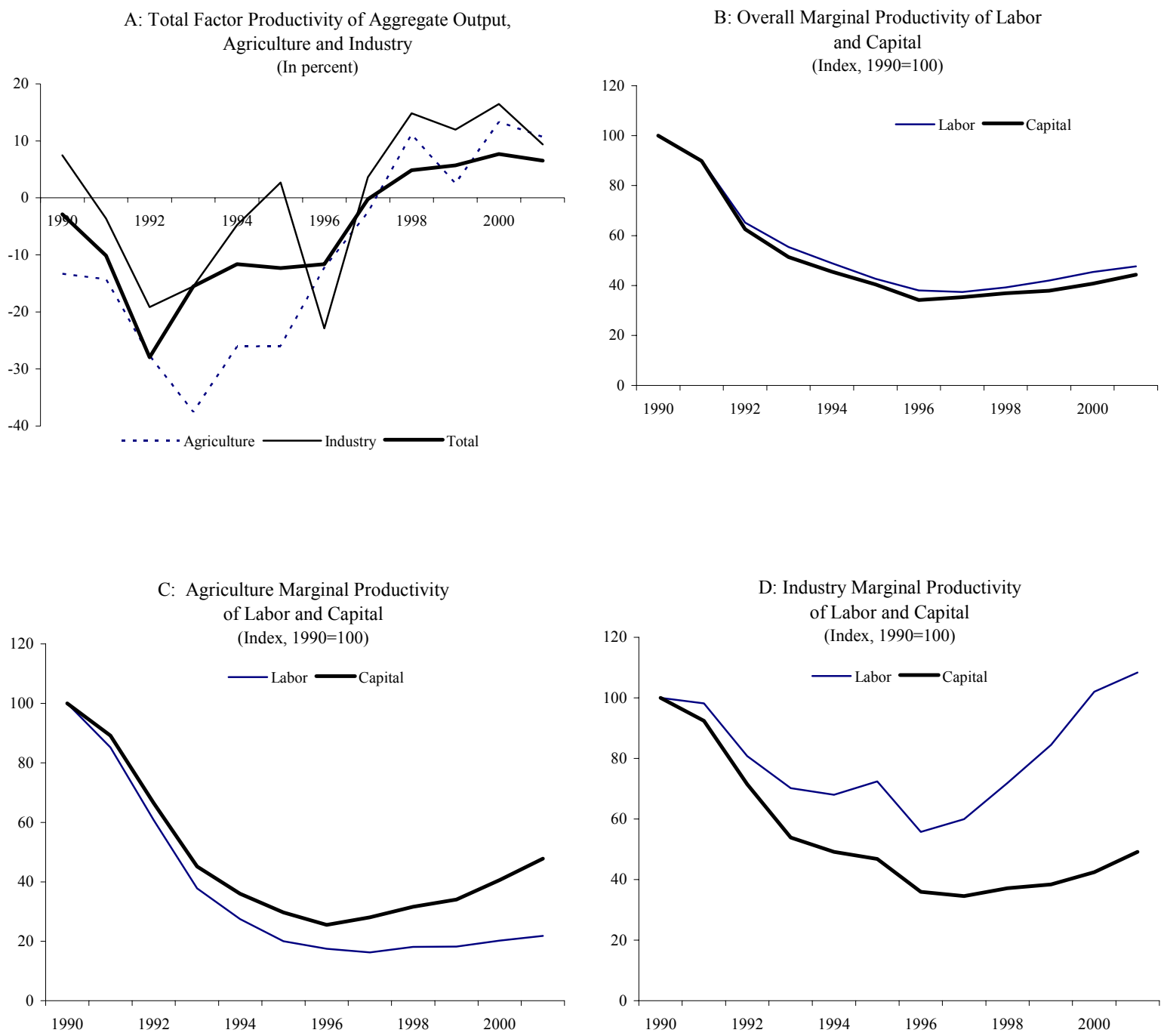

Sources: Tajik authorities; and Fund staff estimates.

13. During the early 1990s, both labor and capital growth was negative, reflecting reductions in employment and investment (Figure 3). Total employment fell by 10 percent between 1990-1998. On a sectoral basis, the reduction in employment was particularly pronounced in construction, industry and the services sector. In the agricultural 
sector we see a significant increase in the growth rate of labor, suggesting labor shedding in other sectors and shifting towards agriculture. The decline in capital inputs in the agricultural sector reflects a movement away from traditional capital-intensive farming to subsistence farming.

Figure 3. Growth Rate of Capital and Labor
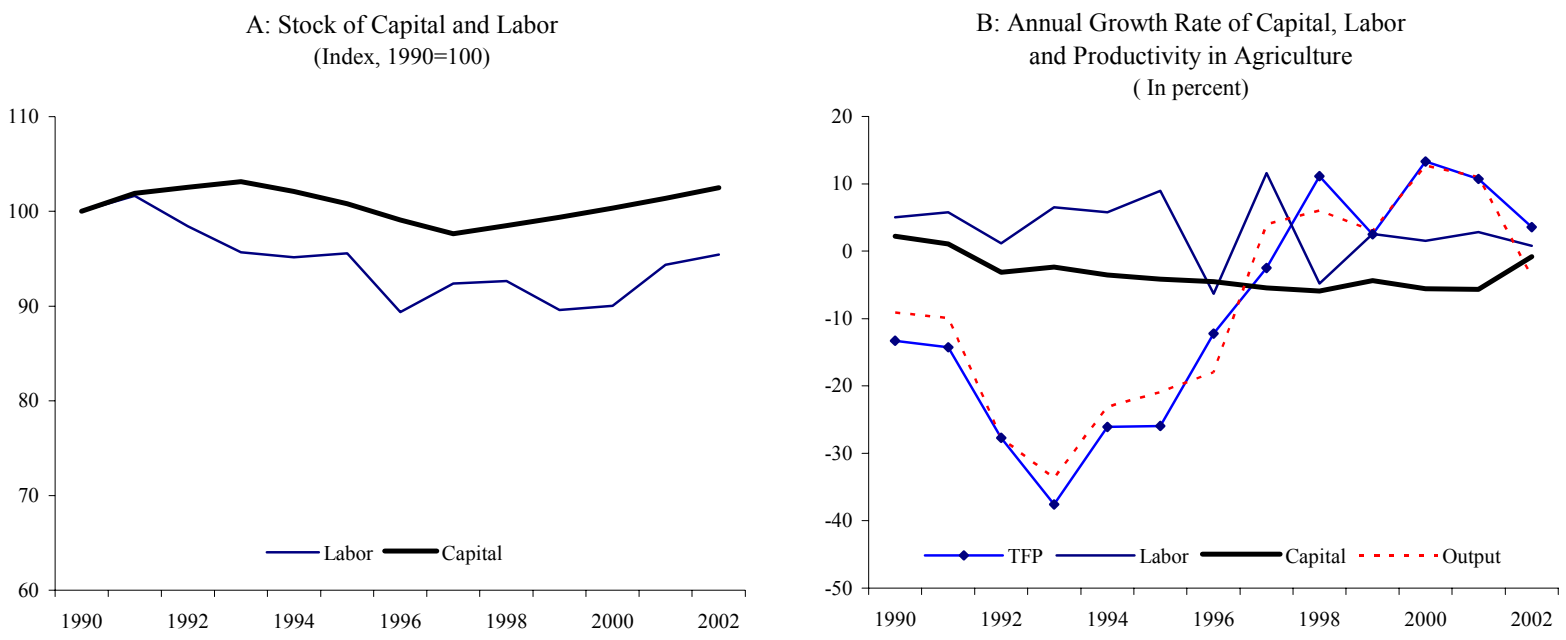

C: Annual Growth Rate of Capital, Labor and Productivity in Industry (In percent)

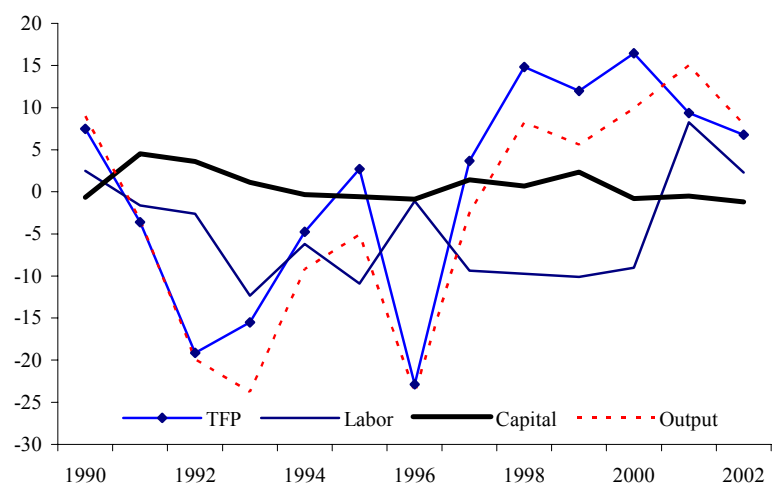

Sources: Tajik authorities; and Fund staff estimates.
D: Overall Annual Growth Rate of Capital, Labor and Productivity (In percent)

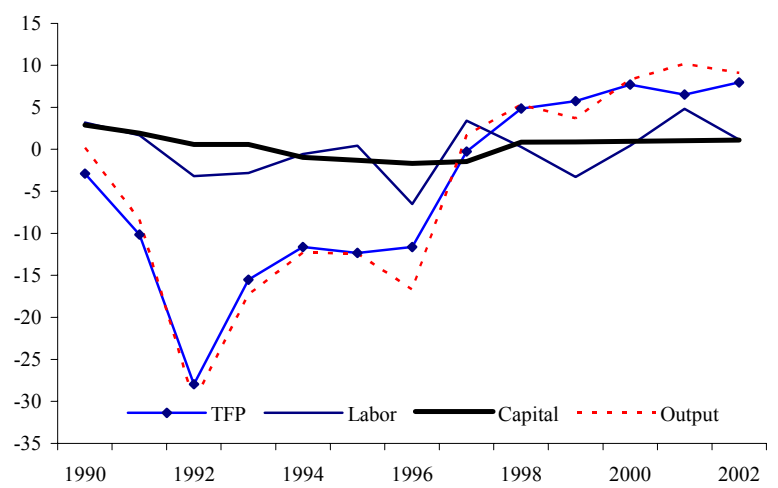




\section{Cross-Country Comparisons}

14. Table 3 below provides a comparison of Tajikistan's growth and TFP performance with a number of CIS-7 countries. In all CIS-7 countries including Tajikistan, capital obsolescence and economic distortions inherited from the central planning system contributed to the significant decline in TFP. However, by 1998 most CIS countries witnessed more efficient use of factor inputs. For all the CIS countries (including Tajikistan), this result should be interpreted with caution as TFP captures not only technological progress, but also capacity utilization, increases in GDP due to regularization of the informal sector, and changes in hidden employment.

Table 3. CIS Total Factor Productivity 1991-2003

(In percent of GDP)

\begin{tabular}{lrr}
\hline & $1991-97$ & $1998-2003$ \\
\hline & & \\
Armenia & -6.5 & 8.0 \\
Azerbaijan & -11.1 & 1.9 \\
Georgia & -10.2 & 6.3 \\
Kyrgyz Republic & -9.4 & 1.3 \\
Moldova & -13.5 & 4.1 \\
Tajikistan & -12.9 & 8.1 \\
Uzbekistan & -3.1 & 3.8 \\
CIS-7 Countries & -9.5 & 4.6 \\
\hline
\end{tabular}

Sources: De Broeck and Koen (2000); and authors' estimates.

\section{E. Conclusions}

15. TFP started increasing in 1998, which suggests that stability and reform efforts are showing some results on the production side. While agriculture production has rebounded, production in the industrial sector is still way below its 1990 level. The significant growth of labor in the agriculture sector has helped to reduce rural poverty.

16. In the short term, the forthcoming FDI-financed investment in the energy sector and the continuing flow of remittances from migrant workers, are expected to sustain the current high growth rates. In the long run, several structural measures are needed to sustain higher growth rates. Investment is restrained by institutional impediments and the restrictive business environment. To achieve higher levels of investment, the authorities will need to create a more supportive business environment by removing ownership restrictions, especially in the banking sector, and enhancing governance and transparency, particularly with regard to tax and business registrations. 


\section{REFERENCES}

Berg, Andrew, Eduardo Borensztein, Ratna Sahay, and Jerromin Zettelmeyer, 1999, "The Evolution of Output in Transition Economies_-Explaining Differences," IMF Working Paper No. 99/73.

Bernard, Andrew, and Charles Jones, 1996, "Productivity Across Industries and Countries: Time Series Theory and Evidence," Review of Economics and Statistics, Vol. 78, No.1, pp 135-46.

Cameron, Gavin, James Proudman, and Stephen Redding, 1997, "Deconstructing Growth in UK Manufacturing,” Bank of England Working Paper No. 73.

Havrylyshyn, O., and R. van Rooden, 2000, "Institutions Matter in Transition, but So Do Policies,” IMF Working Paper No. 00/70.

Koen, Vincent, and Paula De Masi, 1997, "Prices in the Transition: Ten Stylized Facts," Staff Studies for the World Economic Outlook, pp. 128-43. 


\section{Main Elements of The Revised Tax CODE ${ }^{1}$}

1. Tajikistan revised its tax code at the start of 2005 to improve tax administration and reduce the cost of collecting taxes. ${ }^{2}$ The revised tax code eliminates nuisance taxes and enhances incentives for growth of private businesses while reducing incentives for tax avoidance. The revisions streamline taxes on businesses and concessions, increase the VAT threshold, introduce new taxes to broaden the tax base, and strengthen tax collection procedures while protecting taxpayer rights. These revisions are expected to yield a net revenue increase of about 0.5 percent of GDP in 2005. In addition, the tax code streamlines the procedures for taxpayer registration, assessments, audits and refunds in the case of overpayment. It also reduces tax concessions, including tax holidays for corporate businesses, and introduces accelerated depreciation schedules.

2. The revisions to the tax code are expected to yield higher revenues, even in the short term, and to strengthen tax administration and tax yields into the medium term. In 2005, the revenue increase will come mainly from reductions in tax exemptions ( 0.1 percent of GDP); introduction of a minimum corporate tax on enterprises and a unified agricultural tax ( 0.3 percent of GDP; on a gross basis, the yield from these taxes is estimated at 0.6 percent of GDP in 2005); and strengthened procedures for collecting taxes from defaulters ( 0.1 percent of GDP). ${ }^{3}$ The details of the main changes in the tax code are as follows:

- The corporate profit tax on businesses is reduced from 30 percent to 25 percent. Businesses can carry-over losses for only three years, compared to five years under the previous tax system, and tax deductions for repair costs and contributions to charity are doubled. Corporate property taxes are also abolished, and a simplified tax system (with a higher rate of 12 percent) for small businesses with annual turnover below SM 144,000 is introduced (Table 1). This tax replaces the corporate profit tax as well as the minimum tax on enterprises that small businesses were hitherto subject to. In addition, the local retail tax rate is reduced from 5 percent on cash-only sales to 3 percent. Concessions and tax exemptions have also been reduced.

\footnotetext{
${ }^{1}$ Prepared by Francis Y. Kumah.

${ }^{2}$ The customs code was also revised to bring procedures more in line with international practices.

${ }^{3}$ Estimates provided by the Tajik authorities. Slightly more conservative estimates were used in the 2005 budget.
} 
- The VAT threshold is increased from an annual turnover of SM 24,000 (equivalent

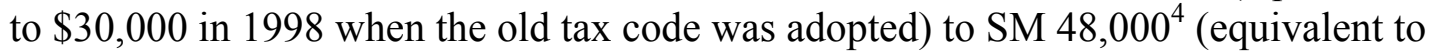
$\$ 16,000)$. The tax authorities hold the view that the increase in the VAT threshold would give the opportunity to improve VAT operations without a significant loss of revenue. This is supported by the low contribution of the small taxpayers, who will be deregistered (but would be classified under the new minimum tax regime for small businesses) and by subsequent concentration of tax efforts and resources on the larger taxpayers. The VAT rate remains at 20 percent.

- The tax base is broadened by introducing two new taxes: the minimum corporate income tax and the unified tax on agricultural sector enterprises. The minimum corporate income tax replaces the abolished corporate property tax. The purpose of the tax is to eliminate the incentives to undervalue the corporate income tax base; the tax will be applicable to loss-making enterprises. The unified tax on agricultural sector enterprises will replace the agricultural VAT, road user tax, land tax, personal income tax on agricultural workers, and agricultural corporate income tax.

- The procedures for collecting taxes from defaulters are clarified (including court action and confiscation of assets) while protecting and supporting tax payers' rights. Under the new tax code, the tax authorities can seize assets and gain access to bank accounts of tax defaulters by court order.

- The personal income tax schedule is revised by reducing the number of tax brackets from four to three. Taxable incomes less than or equal to the monthly minimum wage are zero-rated. The new income tax schedule levies an 8 percent tax on taxable incomes above the monthly minimum wage but lower than SM 100 per month; incomes above this level are subject to a 13 percent tax rate.

\footnotetext{
${ }^{4}$ The VAT registration thresholds in Kazakhstan and Russia are roughly equivalent to annual business turnovers of $\$ 100,000-\$ 120,000$. The Kyrgyz Republic has a lower VAT threshold, but the Kyrgyz authorities plan to increase the threshold to $\$ 120,000$ per year.
} 


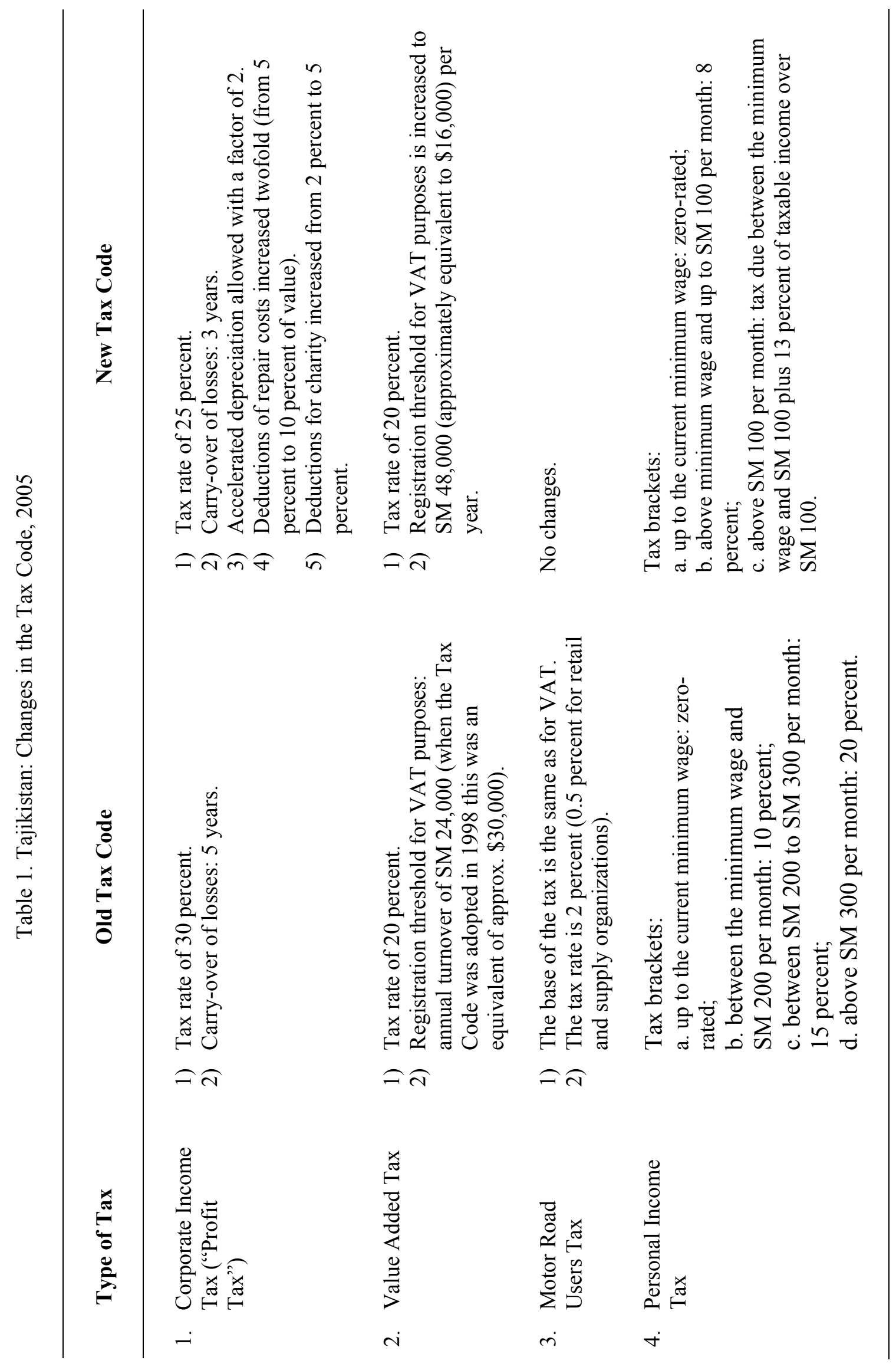




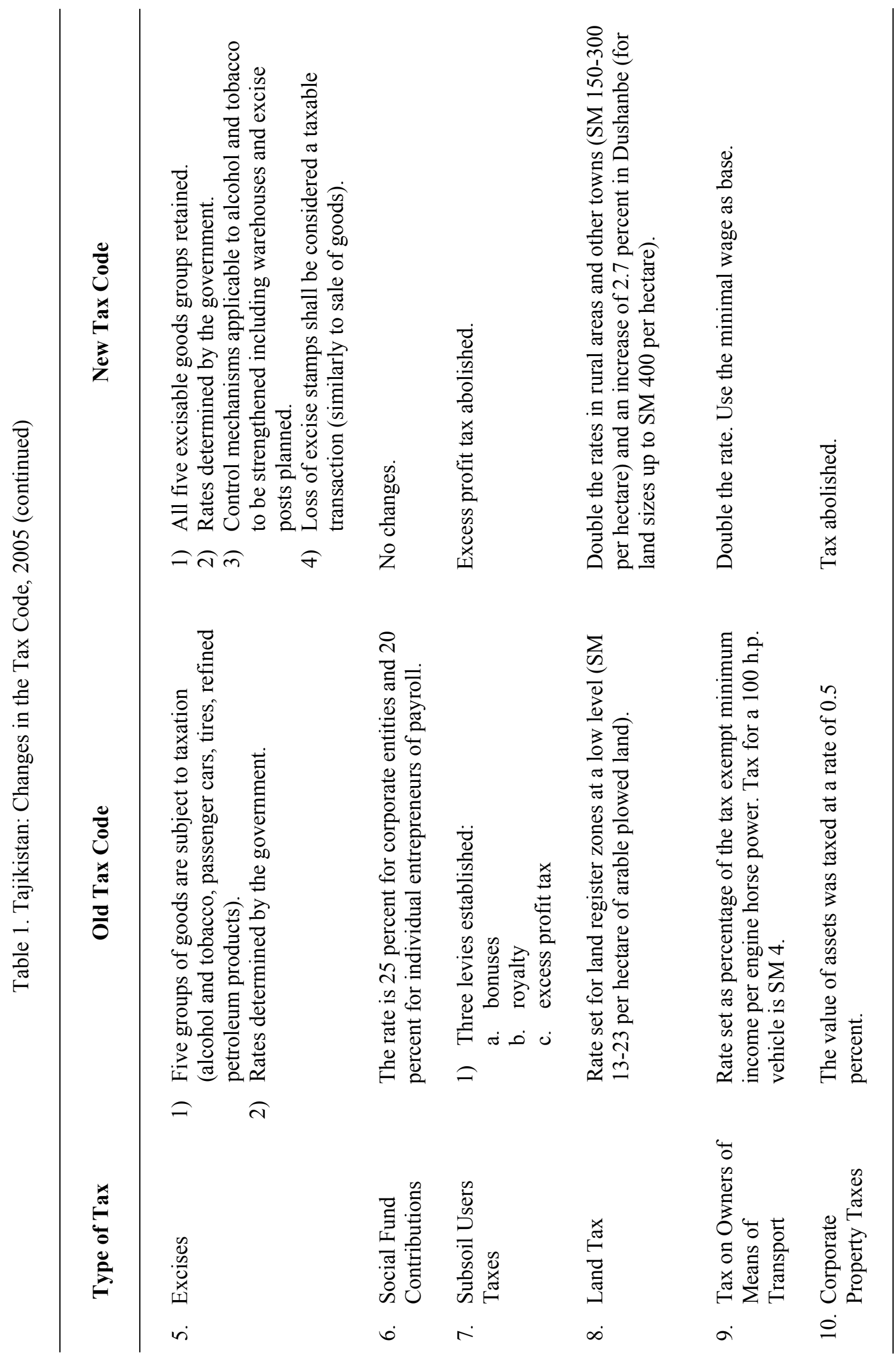




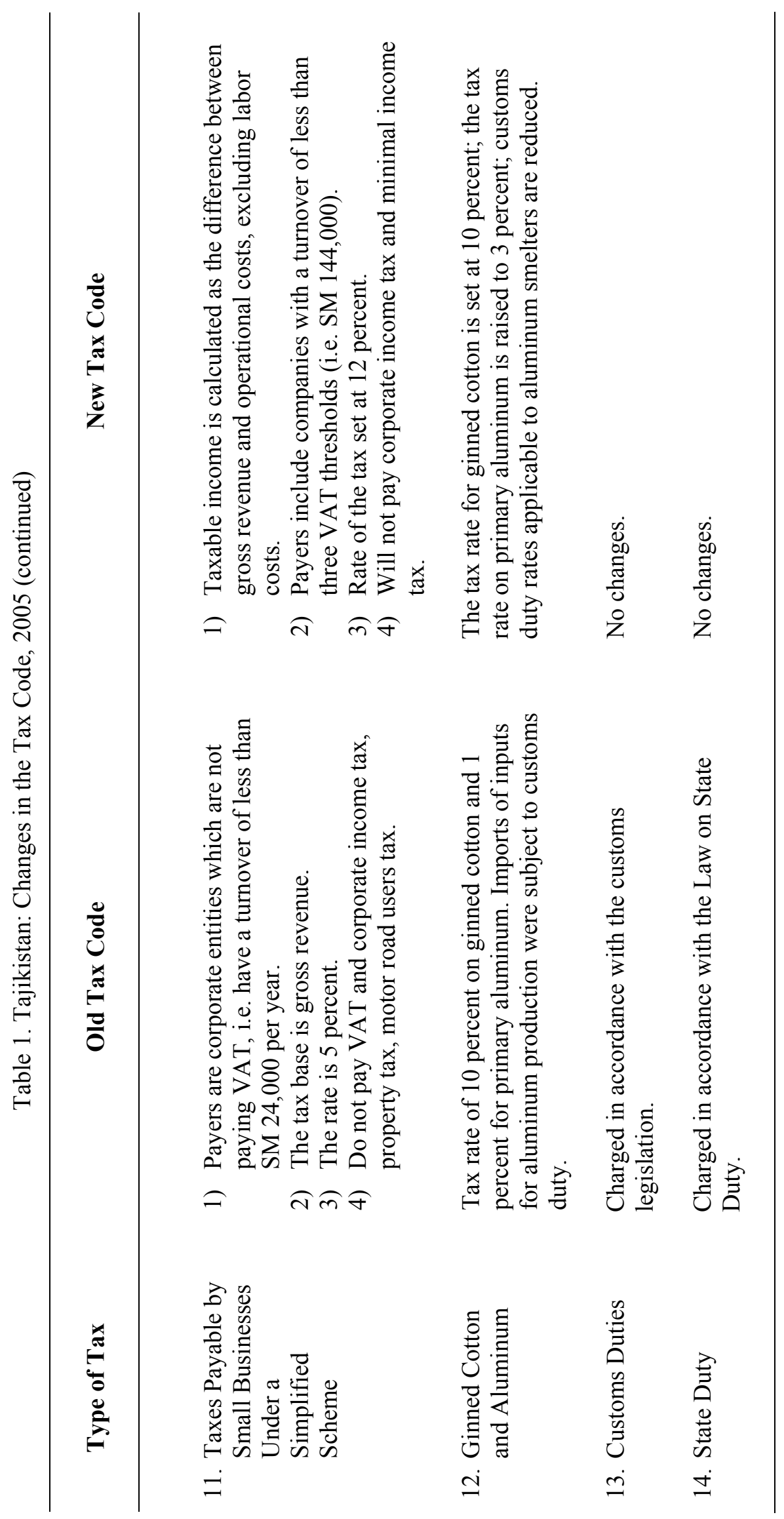




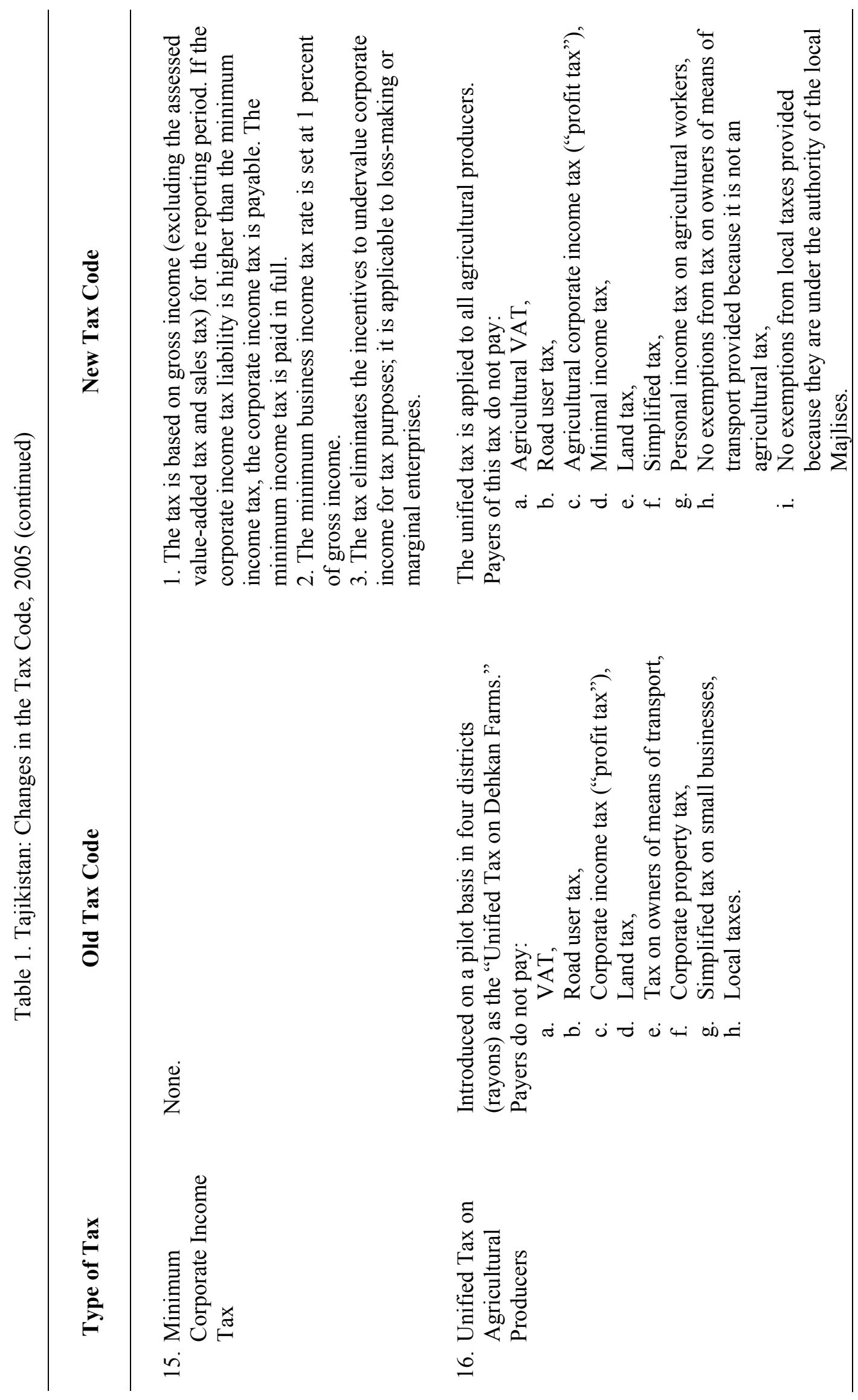




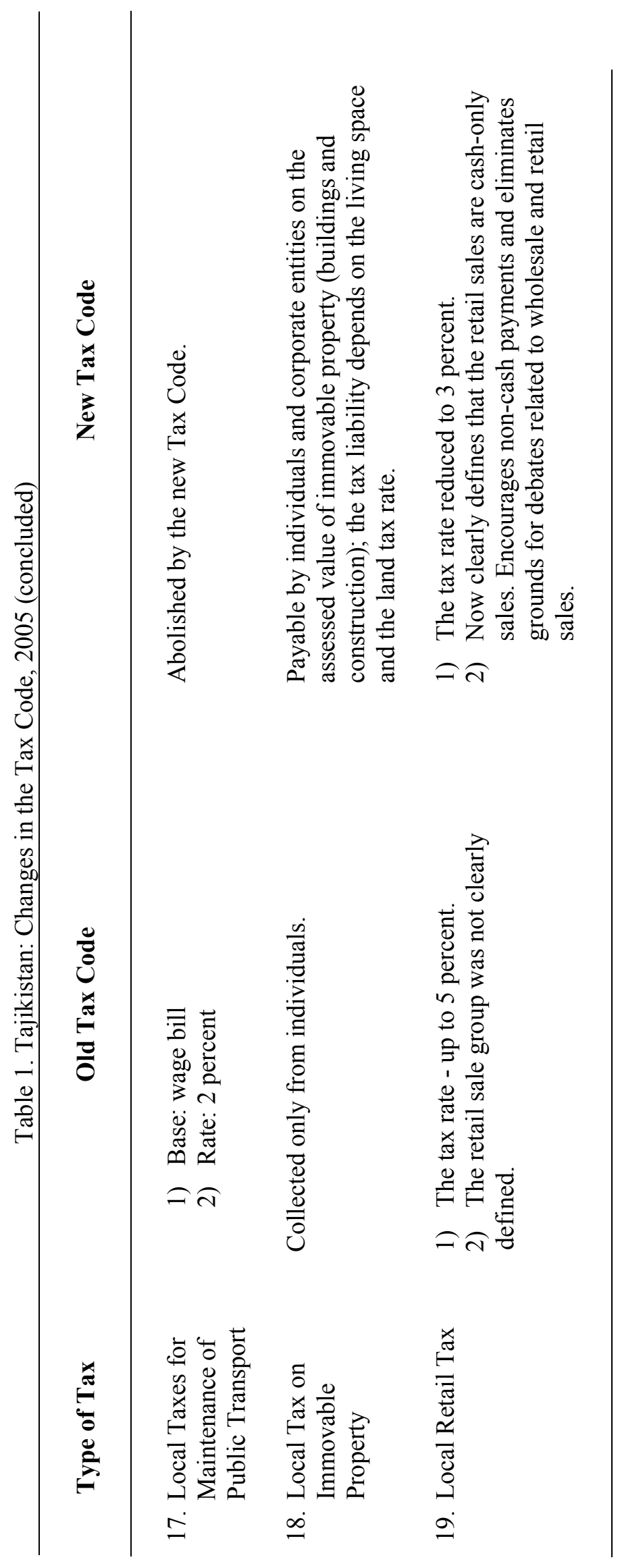




\section{Government Wages In TAJIKISTAN ${ }^{1}$}

This chapter reviews some of the considerations that led the government to include a substantial increase in wages in the 2005 budget. The main factor is the need to catch-up with other sectors in the economy whose wages have increased significantly. Even with this increase, the wage bill is not large by historical standards and in relation to other countries.

\section{A. Introduction}

1. Government wages in Tajikistan continue to be among the lowest in the CIS countries. As economic conditions have improved, private sector wages have increased rapidly. While wages in the government sector have also increased since the late 1990s, they have not kept pace with the increase in nominal GDP and total government expenditures and slipped to 2.7 percent of GDP in 2003-04. Following the civil war, the contraction of the revenue base led to low government wages that in turn contributed to corruption. Under such a weak governance environment, unofficial supplements were condoned as a way of surviving. Recently, as the economy recovers strongly, the government has come under strong pressure to adopt corrective action in this area, especially to address the deterioration in the health and education services. In response, the 2005 budget includes a large wage increase, differentiated by sectors, that raises the general government wage bill to 3.9 percent of GDP in 2005.

\section{B. Recent Trends in Government Wages and Employment}

2. Government wage levels are low and non-competitive, both in comparison with other countries and the domestic private sector. Average government wages (including other employment related supplements) in 2004 were about SM 74 (\$25) per month, just above the poverty line (Table 1). Average wages for teachers and health sector workers, at SM 43 and SM 23 per month, respectively, were even lower (even allowing for the use of vacant positions discussed below). By comparison, the average wage level in the nonagricultural nongovernment sectors (SM 156, \$52 per month) was twice the government level. The low level of government wages reflects limited progress in recovering from the sharp decline in real wages following the Soviet Union's break-up and the civil war in the 1990s.

\footnotetext{
${ }^{1}$ Prepared by Francis Y. Kumah.
} 
Table 1. Wages by Sector, 2000-2004 1/

(In somoni per month)

\begin{tabular}{lrrrrr}
\hline & 2000 & 2001 & 2002 & 2003 & 2004 \\
\hline Total economy & 16 & 24 & 33 & 45 & 61 \\
$\quad$ Agriculture & 8 & 14 & 19 & 27 & 35 \\
Nonagricultural, nongovernment sectors & 35 & 37 & 56 & 87 & 156 \\
$\quad$ Industry & 47 & 71 & 92 & 114 & 144 \\
$\quad$ Transportation & 31 & 49 & 70 & 101 & 148 \\
$\quad$ Construction & 39 & 55 & 75 & 100 & 151 \\
$\quad$ Banking and insurance & 77 & 91 & 118 & 175 & 231 \\
$\quad$ Private enterprises & $\ldots$ & 35 & 62 & 89 & 136 \\
& & & & & \\
General government & 24 & 30 & 49 & 63 & 74 \\
Health care & 7 & 9 & 13 & 17 & 23 \\
Education & 12 & 17 & 26 & 34 & 43 \\
& & & & & \\
\hline
\end{tabular}

Source: State Statistical Committee.

1/ Data based on Statistical Appendix Table 18. In 2004, SM 3 exchanged for US1.

\section{An alternative measure of wages is the size of the government wage bill in}

relation to the economy. This is a broader indicator of remuneration since it also factors in differences in employment levels. For Tajikistan, the general government wage bill was $3 \frac{1}{2}$ percent of GDP in 1998-2002. This compares with central government wage bills in neighboring countries and countries of similar income levels of 5-6 percent of GDP for the same period (Table 2). The average wage bill for PRGF countries during the same period was estimated at 5 percent of GDP. For Central Asia and the Caucasus

Table 2. Central Government Wages and Salaries, 1990-2001

\begin{tabular}{lcc}
\hline & \multicolumn{2}{c}{ Central Government Wages and Salaries } \\
\cline { 2 - 3 } & $\begin{array}{c}\text { In percent of } \\
\text { GDP }\end{array}$ & $\begin{array}{c}\text { In percent of } \\
\text { government } \\
\text { expenditures }\end{array}$ \\
\hline Country Group & & \\
Tajikistan 1/ & 3.4 & 17.1 \\
Central and Eastern Europe & 5.1 & 14.4 \\
Low-Income Countries & 5.7 & 22.6 \\
Middle-Income Countries & 6.0 & 22.1 \\
High-Income Countries & 5.9 & 15.6 \\
PRGF-Supported Programs & 4.8 & 19.9 \\
\hline \multicolumn{2}{c}{ Sources: Government Financial Statistics database (IMF), International Financial Statistics } \\
database (IMF), World Economic Outlook database (IMF), and Fund staff estimates. \\
\multicolumn{1}{l}{ 1/ General government wages and salaries in 1998-2002. }
\end{tabular}
(excluding Tajikistan), the average wage bill was 4 percent of GDP in 2003.

4. The wage bill in Tajikistan declined sharply in 2002-2004. Recent nominal wage increases for government employees were intended to provide for some increase in real wages. However, higher than expected inflation eroded the real value of those nominal wage increases. Also, as the economy expanded faster than projected because remittances boosted incomes and consumption, government wages declined relative to nominal GDP and private sector wages. Government workers have long had nonmonetary fringe benefits. These benefits include generous travel allowances, cars, and mobile phones for senior staff (included in the budget as other goods and services). Other benefits are off-budget, such as land plots for rural teachers. A key benefit for most government workers was discounted gas 
and electricity, but this benefit was removed in 2003 following significant energy price increases.

\section{Faster growth in wages in 2002-04 was envisaged after the start of civil service} reforms. However, these reforms were slow to develop both because vested interests, their complexity, especially in education and health, and inertia related to the low level of wages. In particular, low wages (despite the fringe benefits) created an environment of low morale with a high attrition rate, especially in education and health, where qualified staff have found positions abroad. Moreover, it has been very difficult to attract staff with new technical skills into the civil service.

\section{Employment levels}

6. Excessive government sector employment reduces wages for a given wage bill. For this reason, civil service reforms often look at employment levels. In the case of Tajikistan, core civil service employment numbers are not high by international norms - at 0.6 percent of the population, general government employment excluding education, health and defense is below the norm of 1 percent for low-income countries (Table 3). ${ }^{2}$ Thus, while civil service numbers are not a major problem, the more pressing task is to have civil servants perform adequately the functions needed for a market economy.

Table 3. Government Employment

(In percent of total population)

\begin{tabular}{|c|c|c|c|c|c|c|c|}
\hline & $\begin{array}{c}\text { Civilian } \\
\text { central } \\
\text { government }\end{array}$ & $\begin{array}{c}\text { Civilian } \\
\text { subnational } \\
\text { government }\end{array}$ & Education & Health & Police & $\begin{array}{l}\text { Armed } \\
\text { forces }\end{array}$ & $\begin{array}{l}\text { Total general } \\
\text { government }\end{array}$ \\
\hline Tajikistan 1/ & 0.3 & 0.3 & 3.6 & 1.7 & $\ldots$ & 0.9 & 6.7 \\
\hline Europe and Central Asia & 0.6 & 0.6 & 1.6 & 1.2 & 0.7 & 0.9 & 5.6 \\
\hline Central and Eastern Europe & 0.5 & 0.5 & 1.4 & 1 & 0.3 & 0.8 & 4.5 \\
\hline Low income countries & 0.5 & 0.5 & 0.9 & 0.6 & 0.3 & 0.3 & 3.1 \\
\hline
\end{tabular}

Sources: Tajikistan authorities.

1/ Education and healthcare workforce may be overestimated by 10-30 percent, due to double shifting to offset low wages.

\footnotetext{
${ }^{2}$ However, these numbers are only preliminary and work is on-going to develop more accurate statistics for civil service management. The registry of central government civil service positions has almost been finalized and is expected to show about 15,000 positions ( 0.2 percent of the population). A registry of civil service personnel is expected to be completed shortly afterwards, which will enable a more accurate understanding of the size and distribution of vacancies and would permit a closer alignment between the two registries.
} 
7. Although recorded employment in the education and healthcare sectors looks relatively high, there is a bias in the budget system that leads to underreporting of losses from attrition. Because the budget system is based on the funding of inputs, such as numbers of staff and facilities, there are incentives to maintain the historical count of these inputs to preserve funding. Thus, while actual employment has declined sharply by attrition, the associated vacancies are still included in the budget and remain funded, which allows workers who perform these additional jobs to increase their incomes.

8. The education sector provides an example of this staffing issue. Total employment in education according to MOF records was 220,000 at the start of 2004, with general education accounting for $\mathbf{1 7 0 , 0 0 0}$ positions. Resolution 291, issued on June 2004, envisaged reforms which included cuts in personnel of 5 percent per year, over 5 years. However, when implemented in September 2004, the number of positions was reduced by the full amount (25.5 percent), together with a compensating wage increase. This was possible without significant redundancies owing to widespread vacancies and because many teachers were filling more than one position. Further cuts in the number of positions will be made as the reform process moves forward, including by linking teaching resources more closely with the teaching load and training more teachers to teach multiple subjects. At the same time the actual number of teachers does not appear to be excessive. ${ }^{3}$ Reform plans will also be adopted shortly to address redundancies in recorded positions for higher and preschool education.

\section{Government Sector Reforms}

9. Key aspects of government reform are underway within a medium-term context. ${ }^{4}$ While civil service numbers are not excessive, many criticize government administration as being ineffective in performing the functions of a modern market economy. To some extent, this is an outcome of the lost decade of the 1990s and the absence of any fundamental change in the government's structure since the break-up of the Soviet Union. Many civil servants are focused on administering complex and redundant regulations and processes that interfere with business development. For this reason, the government is reviewing all aspects of the functioning of government and identifying the main problems. Since governmental reform is fraught with many practical difficulties, initial actions and pilot reform programs are planned in key social and economic ministries to modernize their functions, reduce duplication, and improve services to the public.

\footnotetext{
${ }^{3}$ According to UNESCO Education for All, Global Monitoring Report, 2005, student/teacher ratios in Tajikistan based on actual numbers was higher than the average for Central Asia and the Caucasus and about the same as developing countries, excluding Sub-Saharan Africa and South and West Asia.

${ }^{4}$ The accompanying Staff Report for the 2004 Article IV consultation and Fourth Review under the PRGF (Box 4) (www.imf.org) presents a summary of near-term reforms.
} 
10. Reforms in education focus on changing teaching organization, the financing of the sector, and its incentive structure. This is oriented at providing better incentives for the provision of services and balancing the mix of inputs — staff, facilities, and supplies — based on students' needs. In addition to increases in public funding of education, there is a program to formalize and regulate school fees, which would provide additional resource to raise formal wages.

11. Reforms in the health sector are also underway. Based on the work of many donors, wide ranging measures are envisaged that would: (i) shift the focus of health services to primary health care and prevention, which would reduce the need for underutilized and expensive hospital facilities; (ii) shift funding to a per capita basis, possibly with some adjustments to take into account the special circumstances of regions; (iii) establish a set of services comprising a guaranteed benefits package that would be free; and (iv) make other health services optional that would require a co-payment (to replace the informal payments now used), while establishing a set of criteria for patients that would be exempt from the copayments. Overall, this would mean a major change in the operation of medical staff. Although the impact on actual employment is unclear, formal incomes are expected to increase substantially. 


\section{THE IMPACT OF ELECTRICITY TARIFF INCREASES ON HOUSEHOLDS ${ }^{1}$}

This chapter estimates the direct impact of increasing electricity tariffs on households. Also, because this will have an impact on the poor, various mechanisms to reduce this impact are examined. The calculations show that typical pricing strategies are not the most effective way of achieving this objective and that strengthening the direct transfer system is preferable.

\section{A. Introduction}

1. In Tajikistan, low domestic energy prices have been a major constraint on generating the resources needed to finance much-needed investment in the sector. The quasi-fiscal deficit of the energy sector in 2003 is estimated by the World Bank to be 19 percent of GDP. To progressively reduce this the authorities are planning extensive reforms of the energy sector, which are expected to provide more stable domestic supplies and encourage new investment in the sector to exploit its export potential (see Selected Issues Chapter VII). Increases in energy prices should be a key component of these reforms. Although such reforms can generate substantial efficiency and welfare gains for all sectors, they can also reduce the real income of households, especially the poor. The purpose of this chapter is to summarize preliminary work on a Poverty and Social Impact Analysis (PSIA) of the direct impact ${ }^{2}$ of electricity price increases on poor households and compare alternative approaches to mitigating these effects. However, due to the complex policy issues, the impact on farm labor is not examined. While the agricultural sector is heavily dependent on electricity for irrigation, the payment rate is low and many other distortions affect the sector.

\section{B. The Impact of Tariff Structure Reforms on Households}

2. Unlike for gas, where prices have been raised to cost recovery levels, electricity tariffs continue to be well below cost recovery levels. The World Bank has estimated that electricity tariffs will have to increase fourfold to reach cost recovery levels (SM 0.06/kWh or $\$ 0.02$ per $\mathrm{kWh}$ ). Although nearly all households have access to the electricity network, the sector has been characterized by supply shortages, poor service quality, outdated technologies, cross-subsidization of residential consumers by industry, and a widespread tolerance of non-payment of bills. Some reforms were started in 2003 such as the elimination of discounts to "privileged groups" and the introduction of differentiated seasonal tariffs.

\footnotetext{
${ }^{1}$ Prepared by David Coady. Details of the calculations can be obtained directly from the author. It draws from ongoing work with Franziaka Gassmann and Irina Klytchnikova and builds on their previous work (Gassmann, 2004; Klytchnikova, 2004). Work by the World Bank (2004) was also a valuable source of information.

${ }^{2}$ We do not address the indirect income effects arising from the impact of higher electricity costs, and consequently output prices, on the various sectors of the economy. Incorporating these effects would increase the adverse impact on households. In this sense, our estimates in this paper are lower bounds.
} 
Based on electricity demand patterns calculated using the 2003 national household survey, it is estimated that households allocate around 2.3 percent of their total consumption to electricity and this accounts for about 20 percent of the electricity generated.

\section{Use of alternative pricing structures}

3. Table 1 presents the magnitude and distributional impact of alternative tariff structures. The top panel presents the subsidy implicit in each structure as well as the effect on household income and government revenue of moving from the existing structure. The existing system involves lifeline tariffs of SM 0.016 and SM 0.008 per kWh in winter and summer, respectively, both applied to the first $250 \mathrm{kWh}$ monthly energy consumption. The above-lifeline seasonal rates were set at SM 0.027 and SM 0.014 per kWh respectively. The bottom panel presents the share of each quintile in the total absolute subsidy. There are no explicit subsidies for electricity, except for the Energy Compensation Mechanism (ECM) which in 2004 involved spending of 0.3 percent of GDP to compensate for past gas and electricity tariff increases.

4. On average, the subsidy implicit in the existing system is equivalent to 6.8 percent of household income or 3.7 percent of GDP. This is the percentage decrease in income that would result from a complete withdrawal of subsidies and a move to full cost recovery. The highest impact (8.2 percent of household income) would be on the lowest income quintile, compared with 5.9 percent on the highest quintile. Although the existing subsidy distribution is progressive, it is still badly targeted with each quintile receiving similar amounts.

5. One scenario for reducing subsidy levels while maintaining their progressivity is to increase all tariffs and retain lifeline limits but at reduced levels. The second column of Table 1 shows the magnitude and distribution of the subsidy when the lifeline tariff rates are doubled, monthly lifeline limits reduced to $100 \mathrm{kWh}$ and $200 \mathrm{kWh}$ in summer and winter respectively, and above lifeline rates both increased to the cost recovery level of SM 0.06 per $\mathrm{kWh}$. The subsidy decreases to 1.9 percent, falling from 2.3 percent for the lowest quintile to 1.7 percent for the highest. This reform results, on average, in a 4.8 percent decrease in household income relative to the existing structure, with the decrease being greater for the lowest quintile (6.0 percent) than for the highest (4.2 percent). However, the bottom panel indicates that the (lower) subsidy implicit in this tariff structure would not be better targeted than under the existing structure.

6. The third column of results presents the impact of applying the lower lifeline limits only to those households with monthly consumption below these limits. This type of reform is often suggested as a way of improving the targeting of the subsidy while simultaneously decreasing its magnitude. The average subsidy falls to less than one percent of household incomes and subsidy implicit in this tariff structure is similar across quintiles. In addition, targeting of the subsidy worsens in that the middle-income households receive the highest subsidy share. 
7. The above results highlight the fact that electricity price subsidies, whether targeted or not, are not a very effective way to protect the incomes of poor households because of the high leakage of the subsidy to higher income households.

\section{Use of cash transfers}

8. A more effective way of protecting poor households may be to have a social safety net program explicitly targeted to this group. The final column of results presents the magnitude and distribution of net benefits (i.e. the implicit subsidy plus the cash transfer) under the tariff-cum-limit reforms (column 2) plus a direct transfer program. Using characteristics such as household size and composition, age and education of household head, housing characteristics and household assets, all which are typically highly correlated with household income, it is possible to design thresholds to target the benefit to low income households. Under this program nearly 25 percent of households are beneficiaries and the total transfer budget is 0.2 percent of GDP. The average transfer is SM 48 annually, equivalent to 1.5 percent of the average income of the poorest two quintiles. Like all other practical approaches to targeting, this approach is imperfect in the sense that there is still leakage to non-poor households, but 85 percent of beneficiary households fall into the lowest two quintiles. ${ }^{3}$

9. Under such a system, lower income households are provided a greater degree of protection from the adverse income effects of reforms and the targeting of the net subsidy improves. The lowest income quintile still receives a 3.4 percent net subsidy and the reforms now decrease their incomes by only 4.8 percent compared to nearly $6-8$ percent under the earlier reforms. In addition, the lowest quintile now receives 24 percent of total net benefits, compared to around 20 percent or less under the other reform programs. Of course, increasing the size of the cash transfer would further improve the distributional impact of the reforms, even if this were financed by further scaling up the tariff structure.

\section{The Energy Compensation Mechanism}

10. Reflecting the need to compensate for energy tariff increases, the government introduced the ECM in January 2003. Households apply for this program by providing information to their village committee or local government office regarding their income and assets. Based on this information, and possibly a home visit to inspect living conditions, the local office comes up with an estimate of total household income. Households with total income below the district average wage are in principle eligible for the program. Around half

\footnotetext{
${ }^{3}$ Note that, although targeting under this approach is imperfect, the targeting performance is still relatively good compared to experiences in other developing countries-see Coady, Grosh and Hoddinott (2004) for a review of the targeting performance of such programs. Although this performance may be improved through refining the approach used here, it should also be recognized that implementation problems could substantially worsen performance.
} 
of all electricity consuming households are identified as beneficiaries under the program. These households are compensated at lifeline tariffs for energy expenditures up to a certain energy threshold limit, fixed at $100 \mathrm{kWh}$ /month per household in summer (April to September) and $150 \mathrm{kWh} /$ month in winter (October to March). The maximum transfer a household can receive is SM 0.8 per month in summer and SM 2.4 per month in winter, equivalent to SM 19.2 per year, slightly more than $\$ 6$.

\section{Reviewing the system, the government and the World Bank have raised the} following concerns regarding the effectiveness of the ECM: (i) the approach used for determining program eligibility is not conducive to good targeting owing to its reliance on monetary income; (ii) the use of aggregate monetary income rather than a per capita measure biases the eligibility against large households; (iii) the use of district-level wages as a threshold for program eligibility is inconsistent with the program objective of protecting the most vulnerable households regardless of location; (iv) using energy companies to transfer resources to households by discounting energy bills dilutes their incentives to improve metering and collection services, adds an unnecessary extra administrative burden, and distracts them from focusing on the efficient execution of their primary activities; $(v)$ the administrative process for selecting beneficiaries needs to be streamlined to avoid unnecessary administrative costs and costs associated with applying for the program; and (vi) the size of the payment per household is very small, especially in relation to administrative costs. A recent Fund technical assistance identified a number of design and implementation changes that could improve the effectiveness of the program, including introducing an element of geographic targeting of the transfer budget.

\section{Concluding Remarks}

\section{Increasing electricity tariffs to cost recovery levels in Tajikistan would require} substantial adjustments in domestic electricity prices, with an adverse impact on the real incomes of the poor. It is therefore important to identify the likely magnitude of this impact as well as the most effective way of protecting the poorest households. The PSIA on which this chapter is based is intended to contribute to the discussion of such mechanisms. The associated 8 percent income loss for the poorest households can be mitigated by phasing the tariff increases over 5 years. Although maintaining lifeline tariffs can also help, the implicit subsidies inherent in this approach are not well targeted, with substantial leakage to higher income households.

\section{Well-targeted social safety net programs can provide a higher level of protection} to the poorest households and substantially improve the targeting performance of the overall reform program. In addition, the introduction of such a direct compensation program allows electricity companies to follow a more efficient pricing and operational structure. Higher prices also promote more efficient energy consumption patterns by both households and other users by reducing unnecessary use and switching to alternative cheaper sources. However, before moving to cash transfers the additional administrative costs and implementation problems need to be considered, as well as the current poor payment record due to the low number of metered households. Given the small size of the average transfer, 
over time it may be better to incorporate the compensation payments into the general transfer system, which would allow for improvements in targeting. In view of the time and resources needed to develop and implement an efficient a direct transfer mechanism that effectively reaches the poorest households, lifeline tariffs could serve as a transitional measure.

\section{REFERENCES}

Coady, D. (2004): “Tajikistan: Review of the Energy Compensation Program”, IMF Aide Memoire, December.

Coady, D., M. Grosh and J. Hoddinott (2004): Targeting of Transfers in Developing Countries: Review of Lessons and Experiences. Regional and Sector Studies, World Bank and International Food Policy Research Institute, Washington D.C.

Gassmann, F. (2004). "Republic of Tajikistan: Poverty and Social Protection - Update", September 2004.

Klytchnikova, I. (2004). "Note on energy use in Tajikistan: Evidence from survey data", August, World Bank, mimeo.

World Bank (2004). “Tajikistan Energy Utility Reform Review: A Strategic Approach to Sector Development", Infrastructure and Energy Department, ECA Region, May. 
Table 1. Distribution of Electricity Tariff Reform Burden

\begin{tabular}{|c|c|c|c|c|}
\hline $\begin{array}{c}\text { Consumption } \\
\text { Quintiles }\end{array}$ & $\begin{array}{l}\text { Existing Tariff } \\
\text { Structure }\end{array}$ & $\begin{array}{c}\text { Tariff and Limit } \\
\text { Reforms }\end{array}$ & $\begin{array}{l}\text { Reforms with } \\
\text { Targeted Limits }\end{array}$ & $\begin{array}{c}\text { Reforms with Cash } \\
\text { Transfers }\end{array}$ \\
\hline \multicolumn{5}{|c|}{ Implicit subsidy as percent of income } \\
\hline Lowest & 8.2 & 2.3 & 0.2 & 3.4 \\
\hline $2^{\text {nd }}$ quintile & 7.1 & 2.0 & 0.2 & 2.7 \\
\hline $3^{\text {rd }}$ quintile & 6.6 & 1.9 & 0.2 & 2.2 \\
\hline $4^{\text {th }}$ quintile & 6.0 & 1.8 & 0.1 & 2.0 \\
\hline Highest & 5.9 & 1.7 & 0.1 & 1.8 \\
\hline All & 6.8 & 1.9 & 0.2 & 2.4 \\
\hline Subsidy/GDP & 3.7 & 1.1 & 0.1 & 1.3 \\
\hline Reduction (percent) & & 71.2 & 97.7 & 65.0 \\
\hline \multicolumn{5}{|c|}{ Share of total implicit subsidy (in percent) } \\
\hline Lowest & 20.3 & 19.9 & 19.9 & 24.0 \\
\hline $2^{\text {nd }}$ quintile & 20.0 & 20.0 & 18.9 & 21.5 \\
\hline $3^{\text {rd }}$ quintile & 20.1 & 20.4 & 24.8 & 19.3 \\
\hline $4^{\text {th }}$ quintile & 19.4 & 20.0 & 18.5 & 18.1 \\
\hline Highest & 20.1 & 19.7 & 17.8 & 17.1 \\
\hline
\end{tabular}

Note: Summer electricity expenditures are taken directly from the 2003 Tajikistan Living Standards Survey and quantities derived by applying the tariff schedule for the relevant period. Winter expenditures are estimated using a simple demand model. The resulting quantities are scaled up to match the residential electricity use available from utility data. The cost recovery tariff (CRT) is taken to be SM $0.06 / \mathrm{kWh}$. The average tariff under the existing tariff structure is approximately SM $0.0154 / \mathrm{kWh}$, equivalent to nearly 26 percent of CRT. 


\section{BANKING SECTOR DEVELOPMENT AND REFORM ${ }^{1}$}

The level of financial intermediation in Tajikistan is among the lowest in the world. However, recent progress in achieving macroeconomic stability and improving confidence in the banking system, as well as several specific measures to strengthen the financial sector considered by the authorities, should support rapid growth of the sector and contribute to Tajikistan's economic development.

\section{A. Introduction}

\section{Improved macroeconomic stability and enforcement of banking regulations} contributed to the strengthening of the banking system in the past three years. Enforcement of prudential requirements has been tightened, resulting in the exit of a number of weak banks and an overall improvement in the financial condition of the banking sector. Remaining banks have generally become more cautious in their lending. Furthermore, the divestiture of Agroinvestbank (AIB) at the end of 2003 through the spin-off from AIB of its cotton industry related lending had a profound impact on the structure and condition of the Tajik banking sector. Today, most of the financial soundness indicators (FSI) compare favorably relative to international norms.

2. The small size of the banking sector poses a major challenge to the Tajik authorities. The level of financial intermediation is amongst the lowest by international comparison. By the end-2003, total loans, including to the cotton Table 1. Deposit Money Banks' Claims on the Rest sector, represented 9.1 percent of GDP (see Table 1). As of September 2004, when mostly foreign-financed lending to the cotton sector was no longer intermediated by AIB, loans of the banking sector fell to an equivalent of just 3.4 percent of GDP.

Deposits barely reached 4.3 percent in 2004. The low financial depth in Tajikistan can be explained by a combination of factors, in of the Economy

\begin{tabular}{lrr}
\hline Country & \multicolumn{2}{c}{2003} \\
& $\begin{array}{c}\text { Percent of } \\
\text { GDP }\end{array}$ & $\begin{array}{c}\text { per capita, in } \\
\text { US\$ }\end{array}$ \\
\hline Estonia & 33.1 & 4,315 \\
Euro Area & 112.2 & 26,875 \\
Kazakhstan & 22.2 & 1,930 \\
Kyrgyz Republic & 4.8 & 457 \\
Latvia & 37.3 & 3,029 \\
Lithuania & 20.6 & 2,947 \\
Russia & 20.9 & 3,257 \\
Tajikistan & 9.1 & 237 \\
\hline
\end{tabular}

Sources: IFS and Development Atlas, World Bank.

Note: Figures are not fully comparable across countries.

particular, years of civil conflict, high inflation and the impact of geopolitical instability in neighboring Afghanistan. Until recently, commercial bank activities have been predominantly focused on providing short-term trade financing, often to bank insiders and related parties, and speculation in the foreign exchange markets. As a result, lending and other fees and profits from foreign exchange operations are the main source of banks' income, with net interest income contributing only 23 percent of banks' gross earnings. Low

\footnotetext{
${ }^{1}$ Prepared by Felix Fischer.
} 
financial intermediation is de facto creating barriers to access to finance and limits private sector-led growth.

3. This chapter first provides an overview of the recent trends in the Tajik banking sector, the regulatory environment (Box 1) and the FSIs, before turning to policy recommendations for developing a deeper financial sector over the medium term.

\section{B. Overview of the Banking Sector}

\section{Banking sector structure}

\section{The banking system is mainly privately owned, relatively small and}

concentrated. In September 2004, Tajikistan's financial sector comprised the central bankNational Bank of Tajikistan (NBT), 12 commercial banks, 5 credit unions and 7 nonbank financial institutions. The sector is highly concentrated, with the four largest banks - the AIB, Orienbank, Tajiksoderotbank, and Amonatbank (saving bank)—controlling 70 percent of assets, 81 percent of household deposits and 71 percent of nongovernment loans.

International Financial Institutions (IFIs) played a key role in improving the operational capacity and loan quality of Orienbank and Tajiksoderotbank through technical assistance, credit lines (in the case of Orienbank), and new injections of capital (Tajiksoderotbank).

5. The banking system has consolidated in the past few years. In 2004, the NBT withdrew the banking license from four banks, bringing the number of closed banks since 1997 to 21. In 2003, NBT granted two new banking licenses, one to a foreign-owned entity and another to an entity with foreign and domestic capital. The recent increase in regulatory minimum bank capital (Box 1) may lead to yet another round of consolidations.

6. At the end of 2003, the AIB, the largest commercial bank was divested. The AIB, deeply insolvent and in chronic violation of prudential norms, was divested through a spinoff from its cotton industry related lending and funding business. The latter was converted into the nonbank financial institution Joint-Stock Company Kredit-Invest. ${ }^{2}$ The remaining bank, still called AIB, was restructured and recapitalized and is now the largest universal bank in the country. ${ }^{3}$ The revitalized AIB accounts for 38 percent of all assets and

\footnotetext{
${ }^{2}$ Kredit-Invest in a nonbank financial institution exempt from prudential requirements applicable to similar institutions. It has a large, mainly non-performing loan portfolio of Som 192 million, or the equivalent of 85 percent of the banking system's loans. Kredit-Invest claims that 20 percent of its loans are performing while another 40 percent can be recovered within three years, provided it obtains political support for contract enforcement. Currently, loan recovery is partially hampered by local governors protecting borrowers.

${ }^{3}$ To strengthen AIB's balance sheet, the government issued to AIB SM 25 million worth of treasury bonds to secure its NPLs. These bonds mature on January 30, 2006; and they earn a low nominal interest rate to encourage AIB to recover as many as possible of the NPLs. By the end of 2003, after
} 


\section{Box 1. Main Recent Legal and Regulatory Changes}

In May 2004, a new microfinance law was enacted. Necessary regulations for the implementation of this law still need to be drafted.

In November 2004, the NBT passed a new regulation for the interbank market, requiring market participants to collateralize transactions with government securities. The procedures for the functioning of this market and the settlement through the NBT are still being worked out. However, the lack of government securities needed for collateral remains the main constraint for the development of a liquid interbank market.

The minimum capital requirement for new banks has been increased to $\$ 5$ million. The new capital requirement is applicable to the four largest banks since January 1, 2005, while smaller banks and Amonatbank have time to comply until January 1,2006 . The minimum capital requirement has also been increased from $\$ 100,000$ to $\$ 300,000$ for credit unions. For existing credit unions, the new regulation will be adopted gradually until January 1, 2006.

After an extensive training period, a new reporting system, consistent with the International Financial Reporting Standards (IFRS) was introduced on February 1, 2005. Resolution 50 requires banks to keep their books according to IFRS. Resolution 290 defines the new charts of accounts.

In early 2004, the liquidity requirements (K2-1: liquid assets/demand liabilities) has been reduced from 75 percent to 30 percent for banks that are in full compliance with the prudential regulations and to 50 percent for banks that are in breach with one ore more prudential requirements. Consistent with international practice, the definition of liquidity now excludes short-term loans. Furthermore, the liquidity requirement K2-2, measuring liquid assets as a percentage of total capital, has been abolished.

Following Instruction 118, banks are now authorized to open banking representations in the vicinity of a bank branch or headquarters. These representations are smaller than branches and do not keep any cash overnight. The presence of banking representation ought to increase banking penetration to remoter areas and promote microcredit.

22 percent of deposits. Its technology is among the most developed in the country, and the AIB was the first bank to offer ATM services.

\section{Amonatbank, the fourth largest bank in Tajikistan, is the only remaining state-}

owned bank. It holds 14.3 percent of the banking system's assets and 8.4 percent of household deposits. Amonatbank has the largest branch network, with 80 branches nationwide, and continues to function primarily as a fiscal agent for the government. The bank delivers pensions and other government transfers to the population and accepts tax payments through its network of branches and agencies. However, electronic connectivity

an injection of new capital of SM 9 million by 11 new local individual shareholders, AIB's net capital reached SM 13.9 million (excluding special reserves for fixed assets and foreign exchange revaluation). 
with its branch network is low. Only 10 percent of the branches' accounts can be consolidated on a daily basis.

8. Deposits grew by over 40 percent per year in 2002-03, but deposit growth fell to 17 percent in 2004. The share of dollar deposits in total deposits has remained stable at about 70 percent in the past few years. The banking system has steadily increased its reliance on deposits as a source of liquidity, so that the share of deposits in total liabilities rose from 24 percent in 2001 to 37 percent in 2003, before increasing sharply to 63 percent during the first nine months of 2004. However, deposits still represent only 4.3 percent of GDP.
Figure 1. Bank Credit to the Economy Excluding Agroinvestbank (in million somoni)

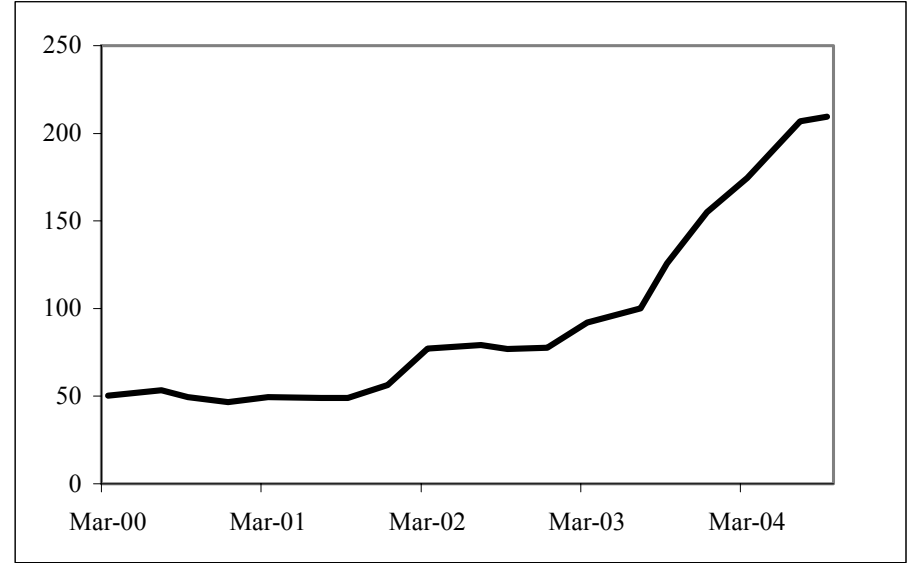

Source: NBT.

\section{Credit to the private sector has been growing considerably faster on average} than in the Baltics, Russia and other former Soviet Union countries (BRO). On average, annual credit growth in the BRO area decelerated from 44 percent in 2000-01 to 17 percent in 2002 and accelerated steadily thereafter, reaching 36 percent in the second quarter of 2004 (Table 2). During 2004, credit growth has been accelerating strongly in the Tajikistan, Kyrgyz Republic, Armenia, Kazakhstan, and Azerbaijan, and has decelerated only in Georgia. In Tajikistan, credit growth to non-cotton sector has been particularly strong. To a large extent the accelerating trend reflects improved confidence in banks and a long-soughtafter financial deepening. Dollarization of the loan portfolio has been declining steadily from 78 percent in 2001 to 62 percent by September 2004.

Table 2. Middle East and Central Asian subregions: Credit to the Private Sector, 2000-04 (Simple average annual percentage change in local currency)

\begin{tabular}{lrrrrrr}
\hline & & & & & \multicolumn{2}{c}{2004} \\
\cline { 6 - 7 } & 2000 & 2001 & 2002 & 2003 & Q2 & Q3 \\
\hline BRO & 47.5 & 41.3 & 17.0 & 30.5 & 35.8 & N.a. \\
of which Tajikistan & 38.1 & 94.0 & 30.1 & 41.7 & 41.3 & 40.4 \\
$\quad$ excluding cotton sector & $\mathrm{n} / \mathrm{a}$ & 21.2 & 37.6 & 100.1 & 106.7 & 66.6 \\
\hline
\end{tabular}

Source: International Financial Statistics and NBT

10. The interbank market remains significantly underdeveloped. The interbank foreign exchange market is very thin and heavily dominated by the NBT, while the somoni market is dominated by bilateral deals. Currently, the government is not issuing any treasury bills. The NBT bills are insignificant in volumes and due to their short maturities 
(28-56 days), they are not suitable for collateralization of interbank lending. Furthermore, market liquidity remains thin; most liquid resources reside with Amonatbank and are invested in NBT bills. The varying credit quality of the financial institutions, the resulting lack of trust between commercial banks, the lack of experience in short-term liquidity management, and uncertainties related to the payment and settlement system hamper the development of the interbank market.

\section{Financial soundness indicators}

11. FSIs are very sensitive to the quality of the reported data, and in particular, the accuracy with which the loan portfolio is classified. FSIs may need to be adjusted after onsite inspection by banking supervision if it discovers inaccuracies in the banks' accounting, and/or after the banks' books have been audited by an independent external auditor. In Tajikistan, five of the large banks have been audited by international auditors. In the first audits, substantial corrections in loan classification were necessary. Auditing firms have reported that after the initial learning phase the audited banks' balance sheets now represent fair value. It can be expected that similar initial adjustments would be necessary in the smaller banks which are not currently audited by international auditing firms.

\section{The FSIs, with the exception of the level of nonperforming loans (NPLs), are} sound and compare well to international benchmarks. Violations of prudential requirements decreased significantly in the past two years, marking a determined effort by the NBT to enforce compliance. Two of the three banks currently violating prudential norms have performance contracts with banking supervision with timetables within which they need to return to full compliance. A similar contract is being worked out for the third violating bank. Although it has declined considerably, the high level of NPLs remains the main weakness of the banking system.

13. The level of NPLs has been steadily declining. The banking system (excluding the AIB $)^{4}$ has come a long way in reducing the NPLs as a percentage of total loans. The NPLs fell from 32 percent in 2000 to 11 percent in September 2004. The improvement in the loan portfolio is showing a steady positive trend (Figures 2 and 3). The reported NPLs in the most recent months may, however, underestimate the magnitude of the problem. This is because problems with loans show up with a time lag. The portfolio quality reported by Amonatbank has been very volatile, partly owing to several rounds of quality assessments and subsequent reclassifications, but probably also underestimated due to the recent rapid credit expansion (Figures 4 and 5).

\footnotetext{
${ }^{4}$ Data including AIB would be misleading as nonperforming loans had not been consistently included in the balance sheet throughout the analyzed time period.
} 
Figure 2. Loan Classification of Total Banking System Excluding Agroinvestbank, March 2000 - September 2004 (in millions of somonis, end of period)

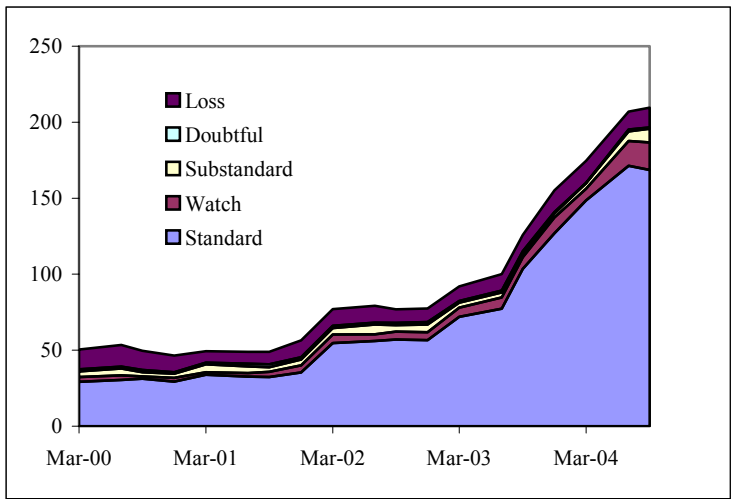

Source: National Bank of Tajikistan.

Figure 4. Loan Classification of Public Bank (Amonatbank) March 2000 - September 2004 (in millions of somonis, end of period)

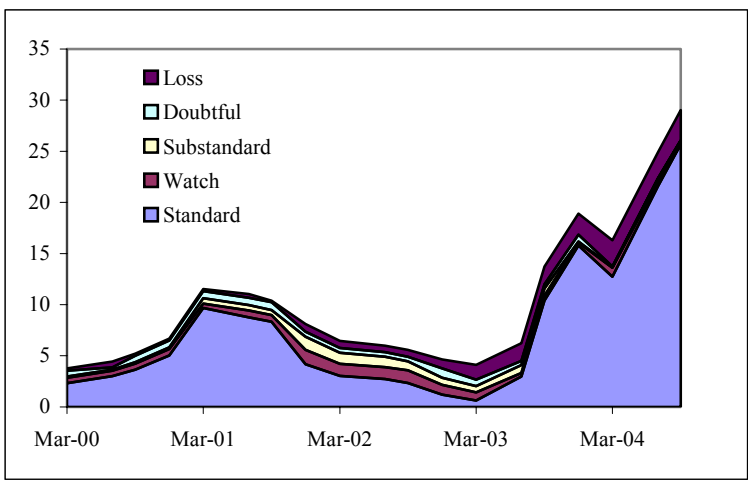

Source: National Bank of Tajikistan.
Figure 3. Loan Classification of Total Banking System Excluding Agroinvestbank, March 2000 - September 2004 (in percentage of total loans, end of period)

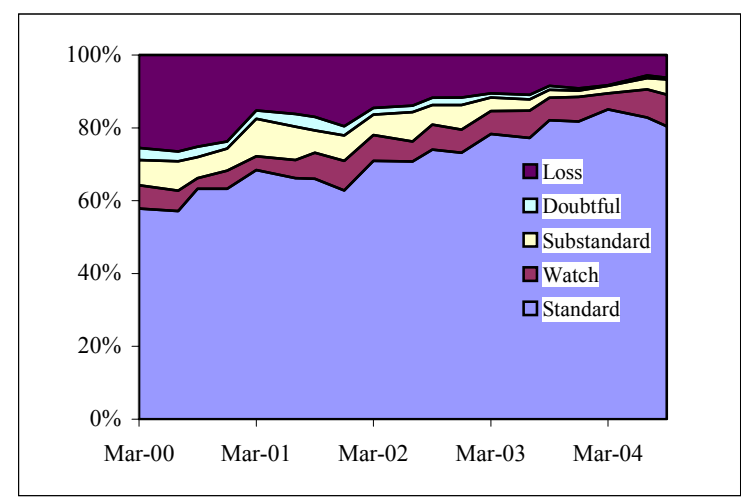

Source: National Bank of Tajikistan.

Figure 5. Loan Classification of Public Bank (Amonatbank) March 2000 - September 2004 (in percentage of total loans, end of period)

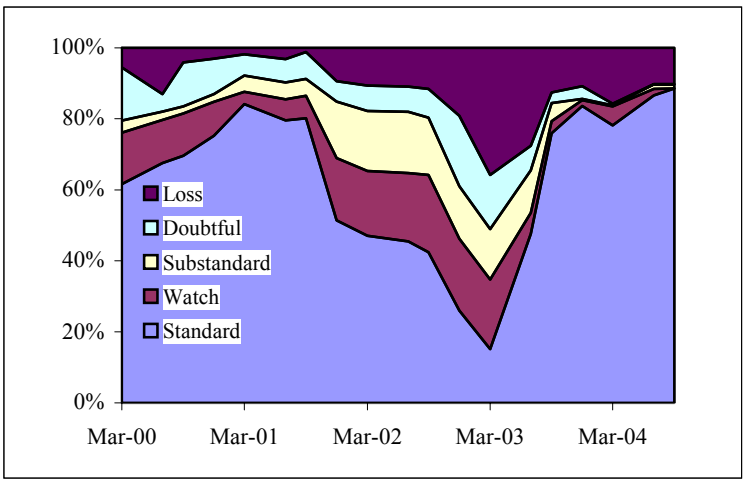

Source: National Bank of Tajikistan.

\section{The current ratio of NPLs to total loans of $\mathbf{1 0 . 9}$ percent remains very high by}

international norms. The NPLs account for 5 percent in the global sample, and for 3 percent for European and 1 percent for U.S. banks (Table 3), well below the level in Tajikistan.

Other FSIs, in contrast, appear to be sound. The ratio of NPLs-net-of-provisions to capital, at 3.6 percent, is in fact lower than in the global and European samples. Although provisions as a percentage of NPLs, at 83 percent, are below the benchmark of 139 percent in the global sample, they are nonetheless substantial, especially compared to other developing countries. 
Table 3. Financial Soundness Indicators, 2001 - September 2004 (excluding Agroinvestbank, in percent, unless otherwise indicated)

\begin{tabular}{|c|c|c|c|c|c|c|}
\hline & \multicolumn{6}{|c|}{ International benchmarks (end 2002) 3/ } \\
\hline & 2002 & 2003 & Sept. 04 & $\begin{array}{l}\text { Global } \\
\text { sample }\end{array}$ & $\begin{array}{r}\text { European } \\
\text { Sample }\end{array}$ & US sample \\
\hline \multicolumn{7}{|l|}{ Capital adequacy } \\
\hline Total net capital to unweighted assets $1 /$ & 14.9 & 17.8 & 25.9 & & & \\
\hline Reported total capital to risk weighted assets (K1-1) & -10.9 & -3.0 & 37.5 & & & \\
\hline \multicolumn{7}{|l|}{ Asset quality $2 /$} \\
\hline Nonperforming loans to gross loans & 20.5 & 11.5 & 10.9 & 5.0 & 3.2 & 1.0 \\
\hline Nonperforming loans net of provisions to capital & 2.3 & 2.3 & 3.6 & 3.7 & 6.7 & -5.3 \\
\hline Provisions to nonperforming loans & 93.0 & 89.9 & 82.8 & 139.0 & 129.0 & 185.0 \\
\hline \multicolumn{7}{|l|}{ Earnings and profitability } \\
\hline Reported return on assets (ROA) & 18.0 & 10.6 & 3.4 & 0.7 & 0.6 & 1.6 \\
\hline Reported return on equity (ROE) & 14.9 & 1.4 & 12.0 & 9.2 & 13.7 & 15.2 \\
\hline Interest margin to gross income & 20.2 & 10.9 & 23.8 & & & \\
\hline Non-interest expenditures to gross income & 47.5 & 46.1 & 53.8 & 63 & 62 & 60 \\
\hline Salary expenditures to non-interest expenditures & 29.4 & 28.2 & 26.7 & & & \\
\hline \multicolumn{7}{|l|}{ Liquidity } \\
\hline Liquid assets to total assets & 14.6 & 22.1 & 37.3 & & & \\
\hline Liquid assets to demand and savings deposits & 88.1 & 124.7 & 136.9 & & & \\
\hline Liquid assets to total deposits & 75.6 & 75.6 & 75.6 & & & \\
\hline \multicolumn{7}{|l|}{ Sensitivity to market risk } \\
\hline Net open position in foreign exchange to capital & N/A & N/A & 8.8 & & & \\
\hline
\end{tabular}

Sources: National Bank of Tajikistan; Bankscope and Fund staff estimates.

1/ Calculated on the basis of consolidated balance sheets for the banking system. Total net capital includes statutory capital, reserves, retained earnings, fixed assets reserve and currency revaluation reserves.

2/ Nonperforming loans include three loan classifications: substandard, doubtful and loss.

3/ Total 108 commercial banks from Latin America (56), Europe (42) and the U.S. (10).

15. Banks in Tajikistan appear to be generally profitable. Return on assets has been declining from unusually high levels of 18 percent in 2002 to 3.4 percent in 2004, but still score high compared to the international benchmarks. The return on equity ratio, at 12.0 percent, is below the American (15.2 percent) or European (13.7 percent) values, but above the comparator from the global sample ( 9.2 percent). The strong profitability in Tajikistan is to be expected, considering the high country risk, the type of financial services extended, the very high interest rate margins, and the low salaries and other operating costs. Banks receive their largest share of income from commissions for money transfers and trade financing, foreign exchange transactions and, possibly, foreign exchange speculation. Only 24 percent of income is earned from net interest payments. By the end of 2003, the lendingborrowing margin in dollars for maturities of 1-3 months was 9 percentage points, and for maturities of 6-12 months over 10 percentage points. The corresponding lending-borrowing margins in somoni for these same maturities were, however, much lower ( 3 percent and 7 percent), which together with the depreciating trend of the somoni could explain the rising share of loans extended in somoni. The high profitability is also a result of low overhead costs (54 percent) compared to international benchmarks (63 percent). Salaries count for less than 30 percent of banks' non-interest expenditures. Finally, banks appear to be very liquid. Liquid assets account for 137 percent of demand and savings deposits and 76 percent of total deposits. 


\section{Reforms to Deepen the Banking Sector}

\section{The financial sector in Tajikistan remains too small to function as an engine of}

growth. A survey conducted by IFC $^{5}$ highlights that for a large number of small- and medium-size enterprises (SME) lack of access to financing is the most significant problem for conducting business in Tajikistan. The survey found that 82 percent of the respondents do not use bank accounts in their business activities. According to the same report, only 3 percent of SME in need of financing obtained bank loans, while 5 percent received financing from sectoral associations and 13 percent from nongovernment organizations. Past macroeconomic imbalances and high inflation largely explain the low level of financial intermediation in Tajikistan. Recent success at macroeconomic stabilization is a prerequisite for the deepening of the financial market. Additional measures are needed to develop the more traditional banking sector to service medium to large size enterprises, including (i) the opening of the banking system to entry by major international banks (ii) the development of a liquidity market; (iii) a strengthening of contract enforcement; (iv) improved internal and external governance; (v) improved banking expertise; and (vi) further development of microfinance initiatives.

17. Opening of the banking system to entry by major international banks: The experience of other transition and developing countries shows that there are significant benefits to attracting major international banks into the domestic banking systems. Such entry yields numerous benefits, including instant access to banking expertise, capital, increased banking credibility, and the establishment of links to foreign investors.

18. Development of an interbank liquidity market: The main impediment for the development of an interbank liquidity market is the insufficient availability of government securities. In addition to their function as collateral, government securities provide other crucial benefits to financial markets, by: (a) creating a yield curve as a reference rate for pricing credits by commercial banks; (b) offering safe heaven for temporary cash surpluses and opportunities for investment diversification for financial and nonfinancial entities; and (c) helping establish the government's repayment track record needed for international rating agencies to assess sovereign risk.

19. Strengthening of contract enforcement: Credit enforcement has to become credible. This can be achieved by accelerating the resolution of outstanding commercial banks' and NBT's NPLs. The setting up of a credit bureau would promote loan performance, as this would reduce the likelihood of loans being extended by any bank to current defaulters. With a credit bureau in place, loan classification regulations should be further tightened by requiring all banks to rate a client with the lowest classification assigned by any bank within the banking system. Because of the higher provisioning requirement for non-standard loans,

\footnotetext{
${ }^{5}$ See International Finance Corporation (2004), 2003 Business Environment in Tajikistan as seen by Small and Medium Businesses.
} 
banks would avoid lending to clients defaulting with another bank (even with sufficient collateral).

20. Improved internal and external governance: The entrance of reputable foreign banks into Tajikistan's financial sector would bring access to capital, know-how, international financial networks, and best practice management structures with numerous internal and external checks and balances. Furthermore, more transparency in the financial market would improve the functioning of market forces. Financial information should come from banks, banking supervision, and rating agencies. Banks should endeavor to open websites, and regulations should require banks to regularly disseminate an appropriate set of relevant market information. The NBT should publish regular nonmarket sensitive reports on banking supervision. In the medium to long term, banks should be encouraged to obtain a rating by reputable rating firms. Finally, consideration should be given to privatizing Amonatbank. ${ }^{6}$

21. Improved banking expertise: A banking association should be set up to identify reform priorities, coordinate banking sector reforms, and provide feedback on draft legislative and regulatory changes in the financial sector. Banking sector expertise can further be improved by training a critical mass of experts in finance and accounting in universities and the recently established banking institute.

22. Microfinance development: The authorities are keen to expand microfinance. Up to now, most microfinance activity was funded by donors. For example, the European Bank for Reconstruction and Development (EBRD) provided capital and intensive training of loan officers to several local banks. Initially, these banks granted mostly small and short-term loans with maturities of up to one year to finance shuttle trade. ${ }^{7}$ Further development of microfinance activities will focus on increasing the typical loan size to the $\$ 10,000-\$ 50,000$ range and extending loan maturities up to 2 years. The average annual interest rate on the larger loans is expected to decline to 20 percent. This will allow a gradual increase in financing of small-scale production and activities in the services sector. Also, recently established specialized microfinance institutions have started taking deposits from the population, trying to tap to local savings pools, including those accumulated from migrant remittances.

\footnotetext{
${ }^{6}$ There is substantial cross-country evidence that associates state ownership of banks with slower subsequent financial development, lower growth of per capita income, and lower growth of productivity in the non financial sector. See for example, La Porta, Shleifer, and Lopez-de-Silanes (2000), Government Ownership of Banks, NBER Working Paper No. 7620 (March).

${ }^{7}$ Microfinance loans supported by the EBRD ranged from $\$ 50$ to $\$ 10,000$, with an average value of $\$ 2,600$. Most loans were for up to one month and carried an annul interest rate of 24 percent.
} 


\section{REgional COOPERATION IN TRADE AND INVESTMENT ${ }^{1}$}

\section{A. Background}

1. Tajikistan is emerging from years of economic instability and civil conflict and is reintegrating into the world and regional economy. The breakdown of economic links after the demise of the Soviet Union, civil unrest, poor governance and macroeconomic management, difficult political relations with neighbors, and overall geopolitical instability in the region - all contributed to the disruption of Tajikistan's external economic relations in the 1990s. Exports narrowed to a few products, traditional markets were lost, and the payments system was broken. Daily household consumption had to rely to a large extent on humanitarian aid, revenues from small-scale shuttle trade, and remittances sent by a rapidly rising number of Tajik migrant workers employed outside Tajikistan.

2. The economic breakdown was aggravated by Tajikistan's difficult geographical location. Tajikistan is a triple-locked economy: land-locked with no commercial access to sea, even by river; mountain-locked by one of the world's highest mountain-mass - the Trans-Alay Range in the north and the Pamirs in the southeast; and distance-locked. These factors result in one of the highest export costs to international markets. Tajikistan borders four countries (Uzbekistan, Afghanistan, China, and the Kyrgyz Republic), but has only one commercially viable railroad and a few poorly maintained highways to the outside world. The longest borders are with Afghanistan, and with Uzbekistan, which is still largely a command economy.

3. Since 2000 Tajikistan has made substantial progress in reestablishing economic relations with its neighboring countries. Traditional channels of cooperation are being normalized with the countries of the former Soviet Union and new links with the partners to the south, in particular, China, Pakistan, and Iran are being established.

\section{B. Cooperation in Trade}

4. Tajikistan has been actively promoting regional cooperation by participating in regional organizations, although many of them are still at an incipient stage. In addition to CIS, Tajikistan is a member of four regional organizations:

- The Euro-Asian Economic Community (EAEC, comprising Belarus, Kazakhstan, the Kyrgyz Republic, Russia, and Tajikistan), which aims at creating a customs union by end-2006 and, eventually, a single economic space (Box 1).

- The Shanghai Cooperation Organization (comprising China, Russia, Kazakhstan, the Kyrgyz Republic, Tajikistan, and Uzbekistan), which initially focused on regional

\footnotetext{
${ }^{1}$ Prepared by Alexei Kireyev.
} 
security, but has approved a program of promotion of trade and investment. Uzbekistan has floated the idea of a Central Asian Common Market.

External Trade by Regional Group, 2004

\begin{tabular}{lrrrr}
\hline & \multicolumn{3}{c}{ Exports } & \multicolumn{2}{c}{ Imports } \\
\cline { 2 - 5 } & \$mill. & Percent & \$ mill. & Percent \\
\hline Total & & & & \\
Euro-Asia Economic Community & $\mathbf{9 1 5}$ & $\mathbf{1 0 0 . 0}$ & $\mathbf{1 3 7 5}$ & $\mathbf{1 0 0 . 0}$ \\
Belarus & $\mathbf{7 0}$ & $\mathbf{7 . 7}$ & $\mathbf{6 1 4}$ & $\mathbf{4 4 . 7}$ \\
Kazakhstan & 2 & 0.2 & 19 & 1.4 \\
Kyrgyzstan & 4 & 0.4 & 210 & 15.2 \\
Russia & 4 & 0.5 & 53 & 3.8 \\
Shanghai Cooperation Organization & 61 & 6.6 & 333 & 24.2 \\
China & $\mathbf{1 4 0}$ & $\mathbf{1 5 . 3}$ & $\mathbf{8 2 1}$ & $\mathbf{5 9 . 7}$ \\
Kazakhstan & 6 & 0.7 & 57 & 4.1 \\
Kyrgyzstan & 4 & 0.4 & 210 & 15.2 \\
Russia & 4 & 0.5 & 53 & 3.8 \\
Uzbekistan & 61 & 6.6 & 333 & 24.2 \\
Central Asian Cooperation Organization & 66 & 7.2 & 169 & 12.3 \\
Kazakhstan & $\mathbf{1 3 4}$ & $\mathbf{1 4 . 7}$ & $\mathbf{7 6 4}$ & $\mathbf{5 5 . 5}$ \\
Kyrgyzstan & 4 & 0.4 & 210 & 15.2 \\
Russia & 4 & 0.5 & 53 & 3.8 \\
Uzbekistan & 61 & 6.6 & 333 & 24.2 \\
Economic Cooperation Organization & 66 & 7.2 & 169 & 12.3 \\
Afghanistan & $\mathbf{2 5 8}$ & $\mathbf{2 8 . 2}$ & $\mathbf{6 1 9}$ & $\mathbf{4 5 . 0}$ \\
Azerbaijan & 8 & 0.8 & 4 & 0.3 \\
Iran & 0 & 0.0 & 86 & 6.3 \\
Kazakhstan & 30 & 3.2 & 26 & 1.9 \\
Kyrgyzstan & 4 & 0.4 & 210 & 15.2 \\
Pakistan & 4 & 0.5 & 53 & 3.8 \\
Turkey & 0 & 0.0 & 0 & 0.0 \\
Turkmenistan & 140 & 15.3 & 38 & 2.8 \\
Uzbekistan & 8 & 0.8 & 34 & 2.4 \\
\hline Source: Goskomstat of Tajikistan & 66 & 7.2 & 169 & 12.3 \\
\hline
\end{tabular}

Source: Goskomstat of Tajikistan.

- The Central Asian Cooperation Organization (comprising Kazakhstan, the Kyrgyz Republic, Russia, Tajikistan, and Uzbekistan), which focuses on developing consortiums for joint projects in hydroelectricity, foodstuffs, and transport.

- The Economic Cooperation Organization (comprising Afghanistan, Azerbaijan, Iran, Kazakhstan, the Kyrgyz Republic, Pakistan, Turkey, Tajikistan, Turkmenistan, and Uzbekistan), which seeks to develop energy infrastructure, trade, transportation, agriculture, and drug control. 
5. Three main factors motivate Tajikistan's participation in these regional organizations: general formal commercial operations, labor and shuttle trade, and raising Tajikistan's international profile. First, the main purpose of Tajikistan's involvement in regional trade initiatives is to reestablish economic linkages with enterprises in Russia, Kazakhstan, and the Kyrgyz Republic, which were lost with the collapse of the Soviet Union. At the same time, opportunities to establish links with major regional economies, such as China, Turkey, and Pakistan, reflect pre-Soviet Union trade and cultural links. Second, with the intensive migration and shuttle trading, travel linkages, in particular with Russia and China, are important channels for private import. Finally, participation in regional groups is seen as contributing to the effort to raise the international profile of Tajikistan by engaging larger countries (Russia, China, and Turkey) in frequent and meaningful policy discussions.

6. The harmonization of trade policies with other members of the EAEC is high on the list of priorities in regional integration. The Agreement on the Establishment of a Customs Union of February 17, 2000, stipulates that the formation of the customs union should be completed in five years, i.e., by February 2005. (Box 1).

\section{The EAEC members undertook to coordinate their trade liberalization} strategies within the regional and multilateral context. The four EAEC members acceding to the WTO (Belarus, Kazakhstan, Russia, and Tajikistan) undertook to: (a) conduct the WTO accession negotiations individually, while developing and presenting coordinated initial offers on market access; (b) achieve a higher degree of harmonization of national tariffs with the EAEC Basic List, while enhancing its coverage from the current 6,178 to all 11,086 tariff lines; and (c) target the final rates of the common EAEC external tariff at levels below the final tariff rates bound in the WTO, while ensuring adequate protection of the priority sectors of each EAEC member.

\section{The harmonization process resulted in some increase in Tajikistan's external} customs tariff. The simple average tariff has increased from 5 to 7.7 percent. The authorities justify the increased level of protection based on three factors: (i) the previous uniform tariff of 5 percent was a temporary measure introduced in 2002 for a year to allow for a smooth transition from an old - and considerably more restrictive tariff system - to a new, less restrictive system; (ii) the need to harmonize Tajikistan's tariff with that of other members of the EAEC, in accordance with the commitments undertaken under the Agreement on the Establishment of a Customs Union of February 17, 2000, and its basic Harmonized Systembased nomenclature; and (iii) the intention to preserve some leverage on tariff reduction in the upcoming negotiations on the WTO accession. 


\section{Box 1. The Euro-Asian Economic Community Harmonization Techniques}

Harmonization procedures in the EAEC depend on the starting conditions and types of commodities. The basis for harmonization is the Basic List of Common External Tariffs. The list was approved by the EAEC Council in September 2003 and represents an HS-based list of commodities for which tariff rates in Belarus, Kazakhstan, and Russia are identical. The Basic List covers only 6,178 tariff lines, out of 11,086 in the harmonized system. In addition to the Basic List, EAEC members compile other lists:

- A list of commodities for which differences in tariff rates among the EAEC members is less than 5 percent. There are 262 lines in this list (4.2 percent of the total). EAEC members intend to engage in bilateral negotiations with the view to harmonizing the tariffs.

- A list of commodities for which differences in tariff rates among the EAEC members is over 5 percent. There are 1,537 lines on this list ( 25 percent of the total).

- A list of sensitive commodities identified by each member, which would be exempt from common external tariff rates.

During the transition period before the customs union is completed, each member is allowed to exempt up to 15 percent of its trade in sensitive commodities from the commonly agreed tariffs. Tajikistan is allowed to exempt up to 25 percent in value terms but only alumina. The shares and values are reassessed every year.

9. Tajikistan is coordinating the EAEC harmonization with its WTO accession, which is at a negotiating stage. The first meeting of the working party on accession took place in March 2004; the second is scheduled for early 2005. Key issues discussed included: the level of tariff protection for the industrial goods; the maximum level of subsidies in agriculture; and the protection of intellectual property. The Tajik authorities intend to coordinate initial offers on market access with the corresponding offers by the Russian Federation and to bind their tariffs in the WTO at rates above their currently applied rates. This would allow the Tajik authorities to increase their applied rates in case of a need without violating their WTO commitments.

\section{Attracting Foreign Investment}

10. Mobilizing foreign investment for projects of national importance is high on the list of the government's priorities. Tajikistan is well endowed in rich mineral deposits (gold and other non-ferrous metals, coal, and salt) and water, a scarce resource in the region. Water is an important factor in Tajikistan's specialization in cotton cultivation and hydropower generation, the latter, in turn, being the basis for aluminum smelting. The 
government's investment strategy emphasizes the need for attracting foreign investment in key sectors of comparative advantage, which would help increase employment and productivity, raise exports, and contribute to budget revenue and poverty reduction.

\section{Aluminum and energy sectors are the main focus of foreign investment. In} October 2004, Tajikistan signed a seven-year \$1.6 billion (76 percent of GDP) investment package with Russian interests, which at this point should be considered as an expression of interest (most of this financing is still to be raised). It includes the commitment of the Russian Aluminum holding company to invest in the Rogun hydro power station (\$560 million) in 2005-2009, the reconstruction of the TadAZ aluminum smelter (\$160 million), and the construction of two new aluminum plants ( $\$ 600$ million) in 2010 2013. The completion of the power stations will help Tajikistan solve protracted problems of electricity shortages, enhance aluminum production, and start commercial exports of electricity. These agreements are still preliminary and considerably more details about the projects and their export potential will need to be discussed before the investment could materialize.

\section{The agreements on two Sangtuda hydro power stations are closer to the} finalization stage, although the modalities of the projects still remain uncertain. RAO EEC has committed to invest \$200 million in Sangtuda I during 2005-2009, which will complement a $\$ 50$ million investment by the Tajik government on behalf of Russia as part of the debt regularization agreement concluded in October 2004. Iran will invest in the construction of the Sangtuda II power station, which will export to Iran and Pakistan.

\section{Transport infrastructure is also an important area of regional investment}

projects. A number of major infrastructure projects are in different phases of development: roads from Dushanbe through the Anzob tunnel to Khujand (estimated cost of \$360 million); from Dushanbe to the Chinese border ( $\$ 290$ million); and from Dushanbe to the Kyrgyz Republic ( $\$ 110$ million); as well as roads to the Afghan border and bridges over the Pianj river. Iran is providing co-financing in the form of a \$25 million loan and a \$10 million grant for the construction of the Anzob tunnel, the project of major economic significance for Tajikistan. The tunnel is viewed as a major economic link for the central and northern parts of Tajikistan, and for Iran, to Kazakhstan and Russia. China provides partial financing for upgrading the road to the Chinese border, which will give Tajikistan access also to Pakistan and India. The United States, together with Norway, will finance the construction of a new transport bridge to Afghanistan. The rehabilitation of roads, in particular to the Kyrgyz Republic, is viewed as an important commercial bypass of Uzbekistan (see Box 2 on problems related to transit through Uzbekistan).

\section{Conclusions}

14. Tajikistan has taken substantial steps towards reestablishing regional linkages. Cooperation in the areas of investment and trade has contributed to economic growth, the cementing of political relations with neighbors, and the easing of social tensions. Regional cooperation has helped raise Tajikistan's profile in the world by promoting private sector 
development, learning from the experience of others, and facilitating the transition to a market economy. However, the cumbersome transit through Uzbekistan and numerous procedural requirements in Russia and other EAEC countries still need to be addressed on a bilateral and regional basis.

\section{Box 2. The Tajikistan-Uzbekistan Nexus}

Difficult relations with Uzbekistan remain the main bottleneck for Tajik exports. All commercially viable export routes - the only railroad and a few highways - go through Uzbekistan. During the winter closure of the Anzob Pass, Tajik traders have to transit through Uzbek territory even for domestic trade between the south and the north of the country. Because of delays at the border, harassment of traders and bribes, Tajikistan cannot take full advantage of its export potential, especially in agriculture, and incurs substantial export losses, as the cost of delivering perishable produce to the traditional markets in Russia becomes prohibitive.

Part of the problem is due to inefficiencies in Tajikistan. Poor transportation grid, corruption, and cumbersome customs top the list of impediments. As an illustration, a study commissioned by the World Bank found that in Tajikistan there is one security control post every 20-kilometer segment of all major roads leading to foreign markets, with an average bribe required of $\$ 3$ for clearance. The total bribes required for one commercial ride from Dushanbe to the Uzbek border is about $\$ 50$ per truck, similar to the estimated monthly wage in the private sector in Tajikistan. By presidential decree of February 4, 2005, the number of traffic police will be cut by 50 percent.

But the transit crossing of Uzbekistan is much more problematic. The World Bank estimates that non-transport related transaction costs are around $\$ 50$ per ton for the domestic route but can amount up to $\$ 200$ per ton for the route via Uzbekistan. The difference of $\$ 150$ per ton can be loosely interpreted as a cost estimate for the bureaucratic hassle and corruption involved in border crossing and transit through Uzbekistan. There are at least eight types of official fees to be paid for transit through Uzbekistan, which may amount to $\$ 500$ per truck. Official and unofficial transit and border crossing payments in Uzbekistan constitute more than 30 percent of the total road transportation costs from Dushanbe to Moscow. Under the Uzbek regulations, each cargo crossing the Tajik-Uzbek border has to be unloaded on the Tajik side and reloaded on vehicles with Uzbek licence plates. Passengers are required to leave their vehicles in Tajikistan, cross the border on foot, and use Uzbek vehicles in Uzbekistan. 


\section{REFERENCES}

Lev Freinkman, Evgeny Polyakov, Carolina Revenco, Trade Performance and Regional Integration of the CIS Countries, Washington, D.C. : World Bank, 2004 World Bank Working Paper, No. 38.

World Bank. Tajikistan Trade Study, 2005, mimeo. 


\section{Tajikistan: Evolution of the Trade Regime}

Tajikistan's trade regime remains liberal. New customs tariffs have been applied starting on November 1, 2003. All imports from members of the Euro-Asian Economic Community, excluding alumina, are exempt from import duties. The tariff on imported alumina was increased from 2 to 5 percent in November 2003. In addition to import duties, new specific excise taxes were approved on March 31, 2003, and are levied on imports of alcohol (HS 22), tobacco (HS 24), and oil products (HS 27). Other explicit trade restrictions include the licensing of trade in alcohol and tobacco, and other goods restricted for health, security, moral, and cultural reasons. Tajikistan has no export tariff.

\begin{tabular}{|c|c|c|c|c|}
\hline $\begin{array}{l}\text { Trade Policy } \\
\text { Instrument }\end{array}$ & 1995 & 1996 & 2001 & 2004 \\
\hline $\begin{array}{l}\text { Tariff rates: } \\
\text { Minimum } \\
\text { Maximum }\end{array}$ & $\begin{array}{l}2 \text { percent } \\
5 \text { percent }\end{array}$ & $\begin{array}{l}10 \text { percent } \\
25 \text { percent }\end{array}$ & $\begin{array}{l}5 \text { percent } \\
30 \text { percent }\end{array}$ & $\begin{array}{l}2 \text { percent } \\
15 \text { percent }\end{array}$ \\
\hline No. of tariff bands & 2 & 2 & 6 & 6 \\
\hline Simple average & $\ldots$ & $\ldots$ & 8.0 & 7.7 \\
\hline $\begin{array}{l}\text { Goods subject to } \\
\text { specific import } \\
\text { tariffs }\end{array}$ & & None & $\begin{array}{l}\text { Fruit and vegetable } \\
\text { juices, mineral } \\
\text { water, soda, beer, } \\
\text { wine, spirits, } \\
\text { tobacco products }\end{array}$ & $\begin{array}{l}\text { Mineral water, soda, } \\
\text { beer, wine, spirits, } \\
\text { tobacco products }\end{array}$ \\
\hline $\begin{array}{l}\text { Import duty } \\
\text { exemptions }\end{array}$ & $\begin{array}{l}\text { Associated gas, } \\
\text { grain harvesters, } \\
\text { alumina, electricity, } \\
\text { and goods imported } \\
\text { by diplomats }\end{array}$ & Eliminated & $\begin{array}{l}\text { Natural gas, } \\
\text { alumina, electricity, } \\
\text { and grain combines }\end{array}$ & $\begin{array}{l}\text { Natural gas, } \\
\text { electricity, and some } \\
\text { products included in } \\
\text { tariff groups No. } \\
01,04,30,49,51, \\
70,87,93,97\end{array}$ \\
\hline $\begin{array}{l}\text { Export taxes: } \\
\text { Ad valorem } \\
\text { Specific }\end{array}$ & $\begin{array}{l}67 \text { product } \\
\text { categories were } \\
\text { subject to export } \\
\text { duties at the rates of } \\
1-500 \text { percent } \\
\text { On metals }\end{array}$ & $\begin{array}{l}\text { Abolished, effective } \\
\text { March 1, } 1996 \\
\text { None }\end{array}$ & $\begin{array}{l}\text { Sales tax on exports } \\
\text { of aluminum and } \\
\text { cotton. Export duty } \\
\text { on goods produced } \\
\text { by joint ventures } \\
\text { None }\end{array}$ & $\begin{array}{l}\text { Sales tax on exports } \\
\text { of aluminum and } \\
\text { cotton. } \\
\text { None }\end{array}$ \\
\hline Excise taxes & & $\begin{array}{l}\text { Some excise rates } \\
\text { on imported goods } \\
\text { were higher than on } \\
\text { domestic goods }\end{array}$ & $\begin{array}{l}\text { No differentiation } \\
\text { by the origin of } \\
\text { imports or producer }\end{array}$ & $\begin{array}{l}\text { No differentiation } \\
\text { by the origin } \\
\text { imports or producer }\end{array}$ \\
\hline $\begin{array}{l}\text { Quantitative } \\
\text { restrictions: } \\
\text { Import quotas } \\
\text { Export quotas }\end{array}$ & Cotton & None & $\begin{array}{l}\text { Quotas on exports } \\
\text { and imports of } \\
\text { ethyl alcohol } \\
\text { None }\end{array}$ & $\begin{array}{l}\text { Quotas on imports } \\
\text { of alcohol products } \\
\text { and tobacco } \\
\text { None }\end{array}$ \\
\hline $\begin{array}{l}\text { State monopoly on } \\
\text { external trade }\end{array}$ & & $\begin{array}{l}\text { Monopoly on } \\
\text { cotton export lifted }\end{array}$ & None & None \\
\hline
\end{tabular}




\begin{tabular}{|c|c|c|c|c|}
\hline $\begin{array}{l}\text { Trade Policy } \\
\text { Instrument }\end{array}$ & 1995 & 1996 & 2001 & 2004 \\
\hline State orders & $\begin{array}{l}70 \text { percent of the } \\
\text { targeted cotton crop }\end{array}$ & Abolished & None & None \\
\hline $\begin{array}{l}\text { State trading } \\
\text { companies }\end{array}$ & $\begin{array}{l}\text { Tajik Oil, Ministry } \\
\text { of Bread, } \\
\text { Somonion, State } \\
\text { Committee for } \\
\text { Contracts and Trade }\end{array}$ & & & $\begin{array}{l}\text { State enterprises and } \\
\text { joint venture }\end{array}$ \\
\hline $\begin{array}{l}\text { Goods subject to } \\
\text { licensing: } \\
\text { Exports } \\
\text { Imports }\end{array}$ & $\begin{array}{l}100 \text { percent } \\
\text { None }\end{array}$ & $\begin{array}{l}70 \text { percent of the } \\
1995 \text { cotton crop } \\
\text { None }\end{array}$ & $\begin{array}{l}\text { Exports and } \\
\text { imports of tobacco } \\
\text { products, ethyl } \\
\text { alcohol, and } \\
\text { alcohol products }\end{array}$ & $\begin{array}{l}\text { Export and imports } \\
\text { of tobacco products, } \\
\text { ethyl alcohol, and } \\
\text { alcohol products }\end{array}$ \\
\hline Price controls & $\begin{array}{l}\text { Monitoring of } \\
\text { export contracts by } \\
\text { the Tajik } \\
\text { Commodity } \\
\text { Exchange }\end{array}$ & & $\begin{array}{l}\text { Floor on the price } \\
\text { of vodka and arak }\end{array}$ & $\begin{array}{l}\text { Control of tariffs set } \\
\text { by natural } \\
\text { monopolies }\end{array}$ \\
\hline Barter trade & Most of trade & $\begin{array}{l}\text { Prohibited with the } \\
\text { exception of the } \\
\text { inputs included in } \\
\text { list approved by the } \\
\text { government }\end{array}$ & $\begin{array}{l}\text { Prohibited, with } \\
\text { some exceptions }\end{array}$ & $\begin{array}{l}\text { Prohibited, except } \\
\text { for aluminum }\end{array}$ \\
\hline $\begin{array}{l}\text { Prepayment } \\
\text { requirements }\end{array}$ & & $\begin{array}{l}\text { Exports of cotton } \\
\text { fiber, aluminum, } \\
\text { precious metal } \\
\text { products, tobacco, } \\
\text { leather, fertilizers, } \\
\text { and some other } \\
\text { products are subject } \\
\text { to } 100 \text { percent } \\
\text { prepayment } \\
\text { requirement }\end{array}$ & $\begin{array}{l}\text { Exports of cotton } \\
\text { fiber, aluminum, } \\
\text { precious metal } \\
\text { products, tobacco, } \\
\text { leather, fertilizers, } \\
\text { and some other } \\
\text { products are subject } \\
\text { to } 100 \text { percent } \\
\text { prepayment } \\
\text { requirement }\end{array}$ & $\begin{array}{l}\text { Exports of cotton } \\
\text { fiber, aluminum, } \\
\text { precious metal } \\
\text { products, tobacco, } \\
\text { leather, fertilizers, } \\
\text { and some other } \\
\text { products are subject } \\
\text { to } 100 \text { percent } \\
\text { prepayment } \\
\text { requirement }\end{array}$ \\
\hline Import valuation & & & $\begin{array}{l}\text { Valuation of } \\
\text { imports is not } \\
\text { compatible with } \\
\text { WTO requirements }\end{array}$ & $\begin{array}{l}\text { The new customs } \\
\text { Code and customs } \\
\text { valuation of imports } \\
\text { are compatible with } \\
\text { WTO requirements }\end{array}$ \\
\hline
\end{tabular}




\section{LABOR MigRATION AND REMITTANCES ${ }^{1}$}

1. Migrant workers' remittances are a key aspect of regional integration and have played a significant role in supporting economic activity in Tajikistan. According to recent surveys, almost every Tajik family has sent at least one of its members to work abroad. Recent studies of household incomes and expenditure indicate that remittances from labor migrants are an important means for survival of families left in Tajikistan. This trend is likely to continue, and the authorities have taken steps toward regularizing labor migration issues with Tajikistan's neighbors. In October 2004, the authorities signed an agreement on labor migration with the Russian Federation and are seeking to regularize migration rules by simplifying document requirements with other Euro-Asian Economic Community (EAEC) members.

\section{A. Employment Abroad and Remittances}

\section{The role of labor migration and remittances in} Tajikistan's development in recent years has been substantial. Reliable data on migration and remittances are not available and the estimates inevitably vary within wide margins. Depending on underlying assumptions, estimates of remittance inflows in 2004 range from $\$ 433$ million (used in the balance of payments) to about $\$ 1$ billion a year, or from 21 to 50 percent of GDP, respectively (see Annex for the underlying calculations). ${ }^{2}$ Annual labor migration increased steadily in the 1990s and peaked in 1999. With economic stabilization in recent years, labor migration has moderated, although annual levels remain high. The balance of payments statistics cover only remittances made through the banking system. These remittances increased almost tenfold in 2001-2004, as confidence in the banking system improved following reforms at end-2002 that eliminated the 30 percent tax on international transfers of foreign exchange and allowed transfers through Tajik banks without opening a current account.

\begin{tabular}{|lr|}
\hline \multicolumn{2}{|c|}{ Remittances at a Glance } \\
\hline Source country & Percent \\
\cline { 2 - 2 } Russia & 92.3 \\
Kazakhstan & 2.1 \\
Uzbekistan & 1.3 \\
Kyrgyz Rep. & 0.3 \\
Other BRO & 1.3 \\
Other non-BRO & 2.8 \\
Frequency of remittances & 34 \\
monthly & 18 \\
bimonthly & 20 \\
quarterly & 17 \\
semi-annually & 7 \\
annually & 4 \\
other & 17 \\
Amount & 26 \\
less than $\$ 100$ & 26 \\
\$100-250 & 18 \\
\$250-500 & 10 \\
\$500-1,000 & 2 \\
\$1,000-3,000 & 1 \\
\$3,000-5,000 & 0.1 \\
\$5,000-10,000 & \\
over \$10,000 & 44 \\
Source of remittance & 2 \\
salary & 12 \\
non-salary income & 6 \\
pension & \\
alimony & \\
small agro exports & \\
other & \\
\hline Source: NBT February 2004 survey. & \\
\hline
\end{tabular}

\footnotetext{
${ }^{1}$ Prepared by Alexei Kireyev.

${ }^{2}$ This is high by international standards and comparable to Moldova, where recorded remittances reach 25 percent of GDP, Jordan (18 percent), and Albania (15 percent). In other traditionally high remittance countries (Egypt, Morocco, and Tunisia) remittances do not exceed 10 percent of GDP.
} 


\section{Russia is the main destination of labor migration and the largest source of} remittances. According to the 2003 International Organization of Migration (IOM) study, about 90 percent of the Tajik labor migrants stay (legally and illegally) in Russia, and 5 percent in Uzbekistan. Accordingly, money transfers from Russia represent 92 percent of remittances. Half of migrant workers from Tajikistan are employed in housing and industrial construction, a third are involved in trade and services, and the remainder works in gas and oil development, manufacturing, catering, and agriculture. About 60 percent of Tajik migrants have no professional qualifications or skills; those with qualifications include teachers, doctors, engineers, technicians, traders, and farm workers.

\section{B. Macroeconomic Impact of Remittances}

\section{Labor migration and remittances have had a significant positive macroeconomic impact.}

- Remittances provided a precious breathing space for the authorities to recover from the civil disruption of the 1990s. They helped most of the population to offset the income shortfalls caused by the civil war and economic dislocations during the transition, and to ease the overall social strain and pressures on the government.

- Remittances have fueled consumption and growth. A rough approximation suggests that Tajikistan's gross national disposable income (GNDI) per capita, at \$342 in 2004, was at least 15 percent higher and growing faster than the GDP per capita. Remittances of under $\$ 1,000$ a year are spent on consumption, mainly food, clothing, and medical care. Remittances of $\$ 1,000-\$ 5,000$ are used to buy durable goods, finance major family events, such as weddings, invest in home repair and improvement, and finance smallscale import transactions. Remittances exceeding $\$ 5,000$ are mainly invested in rural house construction, while those exceeding $\$ 10,000$ are invested in remodeling city apartments and larger-scale imports.

- Remittances have financed the growing trade deficit and kept the current account deficit manageable. Remittances covered up to 80 percent of the trade deficit, which reached 19 percent of GDP in 2004, driven by high import demand.

- Remittances have helped to strengthen the banking system and enhance competition. With simplified regulations on bank transfers, recipients of remittances do not need to have a current account with the bank to receive remittances, and the banks have to compete with each other and other financial intermediaries (i.e., Western Union) for the clientele. The NBT surveys of remittances revealed that 96 percent of the respondents were satisfied with bank services. However, 82 percent of the respondents were not ready to deposit the remitted funds in the banks, and 62 percent explained this by the need to use money immediately to finance current household and business transactions. 
5. The inflow of remittances presents a significant challenge for macroeconomic management. In a small economy with a shallow foreign exchange market and lack of instruments for the conduct of monetary policy, the sheer magnitude of foreign currency inflows and their pronounced seasonal pattern creates significant problems. The inflows can prompt an appreciation of the national currency, complicate monetary management, and rekindle inflationary pressures. In addition, the continuous exodus of qualified labor and young people from Tajikistan deprives the country of future manpower. Remittancesfinanced investment has so far been largely concentrated in the residential construction and refurbishing rather than commercial investment. Finally, remittances have been volatile and sensitive to the political climate, both in Tajikistan and the host countries.

\section{Conclusion}

\section{Labor migration and remittances will continue to play an important role in} Tajikistan and the authorities need to implement policies to put these resources to their best use. In particular, improving the business environment would stimulate the use of remittances for productive investment. Especially important for this is the strengthening of the financial sector to intermediate savings from remittances to business investment. The importance of labor migration and remittances for the Tajik economy also requires continued efforts to regularize regional relations in this area. The 2004 agreement with Russia on labor migration is a welcome development.

\section{REFERENCES}

Bouhga-Hagbe, Jacques A., Theory of Workers' Remittances with an Application to Morocco, IMF Working Paper No. 04/194; October 1, 2004.

Chami, Ralph; Fullenkamp, Connel; Jahjah, Samir, Are Immigrant Remittance Flows a Source of Capital for Development, IMF Working Paper No. 03/189; September 1, 2003.

Labour Migration from Tajikistan, International Organization for Migration, 2003. 


\section{Tajikistan: Remittances-Methodological Issues}

\section{The amount of remittances shown in the balance of payments may not} accurately reflect actual inflows. The official statistics, which capture only transfers through the banking system, put the inflow of remittances at $\$ 433$ million (21 percent of GDP) in 2004. Rough calculations suggest that the actual remittances may be substantially higher. The authorities estimate the share of migrant workers at about 17 percent of the economically active population, or 300-400 thousand. Under the broader definition, the IOM (2003) report indicated that some 1.2 million Tajik citizens were working abroad in 2001. With an average migrant bringing annually at least $\$ 1,300$ from their income abroad to Tajikistan, annual inflows of remittances are likely to exceed $\$ 1$ billion (50 percent of GDP).

2. The inflows recorded as remittances through the banking system represent a mixture of remittances and export proceeds. According to NBT estimates, such traderelated payments may represent up to 40 percent of total remittances, which points to a substantial overestimation of actual workers' remittances in the balance of payments. Based on a survey of banks and their clients, the NBT established the following statistical treatment of bank transfers endorsed by a Fund technical assistance mission: all single transfers of more that $\$ 1,000$ plus 50 percent of transfers between $\$ 1,000$ and $\$ 3,000$ will be considered workers' remittances; all single transfers of more than $\$ 3,000$ and 50 percent of transfers between $\$ 1,000$ and $\$ 3,000$ will be reclassified as

\begin{tabular}{|lr|}
\hline \multicolumn{2}{|c|}{ Tajik migrant's income statement } \\
\hline Gross earnings & US dollars \\
\cline { 2 - 2 } Fixed expenses & 2,700 \\
Transportation & 410 \\
Border crossing & 330 \\
Other & 30 \\
Variable expenses & 50 \\
Food & 945 \\
Accommodation & 540 \\
Police & 225 \\
Other & 135 \\
Remittance to Tajikistan & 45 \\
\hline Source: WB survey of a typical seasonal worker stayin \\
in Russia 9 months at a time \\
\hline
\end{tabular}
exports. The BOP data are being revised accordingly back to 2003. Further analysis of the flows through banks is needed to estimate a threshold under which current transfers are classified as workers' remittances, with the remainder to be classified as other transfers or export proceeds.

3. The actual inflow of remittances may be substantially higher as amounts brought into Tajikistan outside of the banking system are largely unknown. At least two informal channels are used to remit migrant earnings to Tajikistan:

- Transportation of cash. Because of threat of extortion and physical abuse at checkpoints on the way to Tajikistan, cash deliveries are done mainly by air. With some 23 weekly flights to Dushanbe from Russia by Tajik Air and some local airlines, the air transport is capable to deliver to Tajikistan 200,000 people a year. If half of this number brings an average $\$ 1,000$, at least $\$ 100$ million (5 percent of GDP) should be added to remittances.

- Money 'throwing.' For relatively large amounts usually in excess for $\$ 3,000$, an illegal money transfer network known as "perekidka" (from Russian "перекидка"-throwing, 
juggling, a cardsharper's trick) is used, mainly by shuttle traders and moonlight workers. As these groups of migrants cannot document the legal nature of their income to the remitting bank in Russia, they have to use the throwing system.

\section{All remittances through the banking system are shown as current transfers in} the balance of payments statistics, although part of them can be treated either as trade-related payments or income. According to the International Organization for Migration (IOM) 2003 study, there are three main types of labor migrants:

- Migrants on official or informal contracts with the recipient enterprises (20 percent of all migrants). As such industrial and trade enterprises operate year round, the Tajik migrants usually stay for more than a year abroad and transfer a substantial part of their salaries to relatives in Tajikistan. Their transfers of salaries through the banking system are correctly shown as workers' remittances.

- Crews for moonlight construction and agricultural workers (50 percent). They usually work abroad in March-November, during the most active construction and agricultural season in Russia, and return for winter in Tajikistan, remitting their incomes irregularly and bringing most of them in cash. All their wages and other emoluments should be classified in the income account as compensation of employees, with their expenditure abroad classified in the travel account. Currently, all their remittances are shown in the current transfers account as no reliable data on the length of actual stay abroad are available.

- Shuttle traders (30 percent). Finally, the shuttle traders, the majority of them the best educated part of the Tajik migrants, remain abroad for a short period of time and function either individually or through established networks that operate continuously. Their remittances through the banking system represent a mix of family support, which should be shown as income, and export receipts, which should be included in exports.

The item in the current transfers account on workers' remittances may also capture some bank transfers by Tajiks living abroad permanently to their relatives in Tajikistan. Such transfers should be classified as other current transfers, not as workers' remittances.

\section{In addition to the inflow of remittances, Tajikistan's balance of payments} registers a substantial outflow of remittances. These outflows are estimated at $\$ 120$ million (6 percent of GDP) in 2004 and include transfers by workers from neighboring Afghanistan and Iran, misclassified payments for small imports, and - most likely-drugrelated outflows. On a net basis, remittances through the banking system included in the balance of payments are estimated at $\$ 313$ million (15 percent of GDP). 


\section{External Public Debt Developments and Sustainability ${ }^{1}$}

This chapter reviews the substantial progress made by the Tajikistan authorities in improving external debt sustainability. However, it notes that the debt profile still needs to be managed prudently, especially from a fiscal sustainability perspective.

\section{A. Historical Trends}

1. In 1991, Tajikistan started its development as an independent state without external debt, but debt accumulated rapidly during the 1990s. In the early years of transition, against the backdrop of a chaotic political situation, civil conflict, poor governance and cessation of transfers from the central budget, the authorities had to import petroleum products, grain, and consumer staples, all at market prices. These imports relied initially on short-term suppliers' credits and subsequently on offsets through correspondent accounts in central banks of former Soviet states. As a result, Tajikistan's external debt increased from zero at independence to 15 percent of GDP by end- 1992 and to 60 percent a year later. The explosive

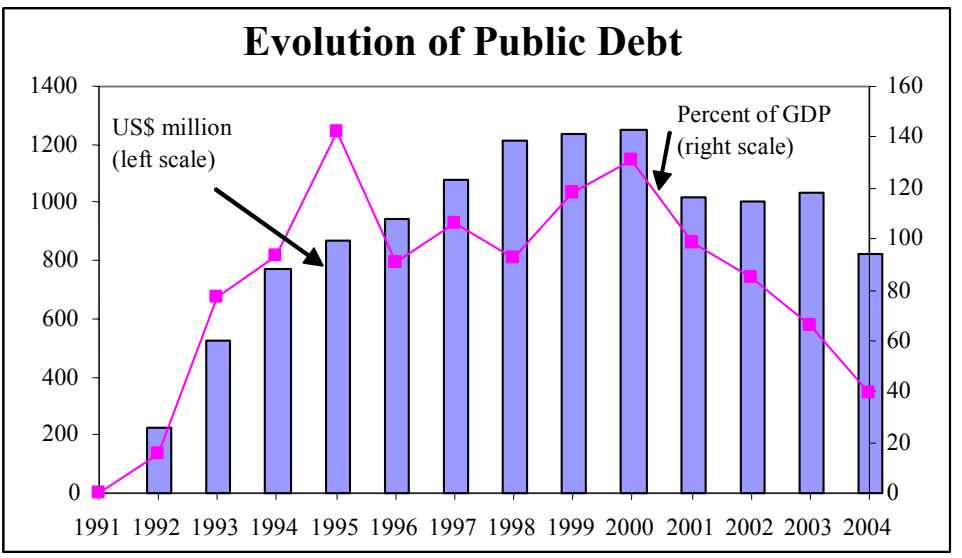
trend in debt accumulation continued through the 1990s and culminated in 2000, when external debt reached 128 percent of GDP.

\section{Attempts to regularize the debt situation began in the mid-1990s but initially} were only partly successful. In 1995, to arrest the buildup of arrears under bilateral trade arrangements with CIS partners, the government announced that it would no longer guarantee payments by Tajik enterprises. In the late 1990s-early 2000s, Tajikistan conducted a series of debt rescheduling negotiations with its main bilateral creditors, which helped to improve its debt service profile, although the terms of rescheduling were not sufficiently concessional to stabilize the debt ratios. At the same time, the authorities started using external concessional loans to finance development projects and accumulated additional debt.

3. Since the early 2000, prudent policies have reversed the pattern of a rising debt burden. The authorities implemented tighter policies on contracting new debt, avoiding nonconcessional borrowing, and limiting new concessional loans under the public investment

\footnotetext{
${ }^{1}$ Prepared by Alexei Kireyev.
} 
program (PIP) to 3 percent of GDP annually. In the absence of an effective debt management system, the ceiling on borrowing under the PIP has helped to restrain and better prioritize externally financed public investment. With a rapid recovery in output and further aggressive debt restructuring and regularization, the ratio of external debt to GDP first stabilized and then started to decline.

\section{B. Recent Developments}

\section{Tajikistan's external debt burden is relatively low compared with most other} low-income countries. At end-2004, Tajikistan's external debt amounted to $\$ 822$ million (40 percent of GDP) and total debt service due was equivalent to 10 percent of relevant exports. ${ }^{2}$ The debt service payments due on government and government-guaranteed debt stood at 15 percent of fiscal revenue. In net present value (NPV) terms, Tajikistan's external public sector debt at end-2004 amounted to about 33 percent of GDP, compared with 72 percent in the Kyrgyz Republic, 53 percent in Moldova, 41 percent in Georgia, and 39 percent in Armenia.

5. At end-2004, multilateral creditors accounted for two-thirds of the debt stock. Two largest multi-lateral creditors are the World Bank and the IMF. Uzbekistan is now the largest bilateral creditor, (after the October 2004 debt reduction agreement with Russia) followed by Russia, the United States, and Turkey. Over half of Tajikistan's external debt is denominated in SDRs, 34 percent is in US dollars, 7 percent is in Euros, and the rest is in other currencies.

Public External Debt at a Glance

\begin{tabular}{|c|c|c|c|c|c|c|}
\hline & \multicolumn{3}{|c|}{2003} & \multicolumn{3}{|c|}{2004} \\
\hline & $\begin{array}{c}\text { US\$ } \\
\text { million }\end{array}$ & $\begin{array}{l}\text { Percent of } \\
\text { total }\end{array}$ & $\begin{array}{c}\text { Percent of } \\
\text { GDP }\end{array}$ & $\begin{array}{c}\text { US\$ } \\
\text { million }\end{array}$ & $\begin{array}{l}\text { Percent of } \\
\text { total }\end{array}$ & $\begin{array}{c}\text { Percent of } \\
\text { GDP }\end{array}$ \\
\hline Total public debt & 1,031 & 100.0 & 66.3 & 822 & 100.0 & 39.7 \\
\hline Government & 827 & 80.3 & 53.2 & 649 & 78.9 & 31.3 \\
\hline Bilateral & 468 & 45.4 & 30.1 & 213 & 25.9 & 10.3 \\
\hline Multilateral & 360 & 34.9 & 23.1 & 436 & 53.0 & 21.0 \\
\hline NBT & 100 & 9.7 & 6.4 & 116 & 14.1 & 5.6 \\
\hline Public enterprises & 103 & 10.0 & 6.6 & 58 & 7.0 & 2.8 \\
\hline Government-guaranteed & 63 & 6.1 & 4.1 & 25 & 3.1 & 1.2 \\
\hline Non-guaranteed & 40 & 3.9 & 2.6 & 32 & 3.9 & 1.6 \\
\hline
\end{tabular}

Source: Tajik authorities.

\footnotetext{
${ }^{2}$ In addition to public sector external debt, which is the subject of analysis in this chapter, there is private external debt incurred mainly by the cotton sector. Data on this debt are not currently available, but can be approximated by foreign liabilities of Kredit-Invest, the bank involved in cotton financing, which reached \$150 million (7 percent of GDP) in 2004.
} 
6. The external debt situation improved markedly in 2002-2004 owing to the reduction in face value and favorable endogenous debt dynamics. The authorities concluded a number of debt cancellation and restructuring (most recently with Russia and Pakistan) which help reduce the face value of external debt by 20 percent in 2004 alone. Also, the government did not contract any new bilateral loans, other than from two development funds (the Saudi Fund and the Kuwait Fund) classified as bilateral lenders. Most bilateral assistance is now

Key Debt Ratios (In percent) provided in the form of grants. Endogenous debt dynamics, in particular from the rapid increase in the nominal GDP, both from the high real growth rate and the improvement in the coverage of previous informal economic activities, have also contributed markedly to the reduction of debt ratios.

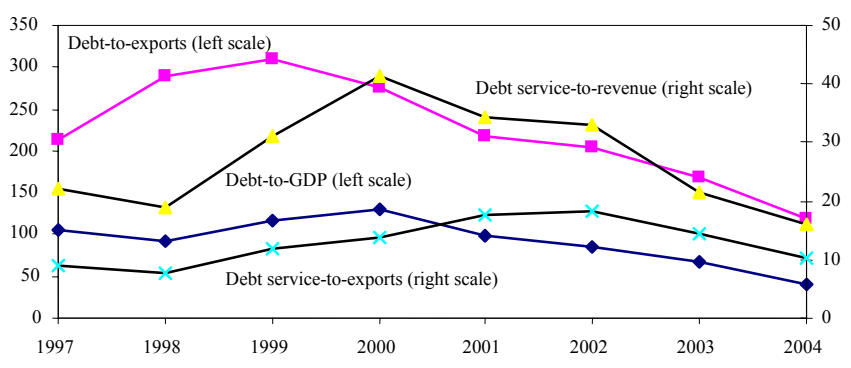

\section{The agreement on regularization of debt with Russia was an important factor} behind the reduction of the debt burden. The agreement signed in October 2004 affecting \$306 million of principal and interest is part of a broader investment package and includes: a debt-for-asset swap of \$242 million; offset of the National Bank of Tajikistan's claims on the Central Bank of Russia; and cancellation of the bulk of the unpaid interest accrued in 2004. Under the swap, \$242 million will be converted into Russia's state ownership of the Nurek space tracking station located in Tajikistan. The formal write-off of the debt will take place after Russia's ownership of Nurek is legally finalized. The government of Tajikistan will repay the remaining $\$ 50$ million by investing this amount during 2005-2008 on behalf of Russia in the construction of the Sangtuda I

\begin{tabular}{lr}
\multicolumn{2}{c}{$\begin{array}{c}\text { Debt Reduction Agreement with Russia } \\
\text { (In millions of US dollars) }\end{array}$} \\
\hline Total debt & 305.7 \\
Stock & 299.7 \\
Interest for 2004 & 6.1 \\
Debt reduction & 254.7 \\
Offset against claims on CBR & 12.3 \\
Principal & 7.2 \\
Interest & 5.0 \\
Debt-for-equity swap & 242.4 \\
Remaining debt & 51.0 \\
Investment in Sangtuda & 50.0 \\
Interest & 1.0 \\
\hline Source: Tajik authorities.
\end{tabular}
hydro-power station.

8. Tajikistan's debt to Uzbekistan has been the subject of protracted negotiations. Uzbekistan's total debt outstanding is $\$ 94$ million. The debt originated from trade credits and negative balances on correspondent accounts opened in the early 1990s in the central banks of both countries for offsets in trade-related payments. This debt has been serviced by offsets with services provided by Tajik Rail for the transportation of Uzbek goods through the Tajik territory. After protracted negotiations, in February 2005 the governments of Tajikistan and Uzbekistan signed an agreement for debt payments in 2004 and 2005. The debt service of \$14 million falling due in 2005 will be paid with services by Tajik Rail. As the offset agreements have to be renegotiated annually, this creates significant uncertainty regarding future debt payments. 


\section{Debt Sustainability}

9. The assumptions underlying this debt sustainability analysis (DSA) include: continued strong real growth of 6.5 percent a year on average in 2005-2010, moderate inflation of 5 percent annually, fiscal deficit, (excluding the PIP) of 0.5 percent of GDP, externally financed PIP at 4.5 percent of GDP, and current account deficit of 4-5 percent of GDP. Commodity prices (aluminum, cotton) and exchange rate projections are based on the January 2005 WEO baseline, updated with recent near-term price movements. The discount rate for NPV calculations is set at 5 percent, and exports are computed as the current year exports of goods and services, excluding barter exports of aluminum and electricity. The DSA is based on the operational framework for low-income countries ${ }^{3}$ adjusted to Tajikistan's circumstances, mainly by calibrating stress tests.

10. Under the baseline scenario, Tajikistan's public debt will remain sustainable in the foreseeable future. ${ }^{4}$ Assuming highly concessional new borrowing and overall prudent debt management, the face value of Tajikistan's public external debt is not expected to exceed 40 percent of GDP in the long-run (Table 1). The non-interest current account is projected to remain close to balance as the trade deficit will be largely offset by net transfers, while FDI, other non-debt creating inflows, and high GDP growth will have a positive impact on the endogenous debt dynamics. In the medium term, reflecting its highly concessional nature, the NPV of Tajikistan's debt will average 31 percent of GDP. The NPV of public debt-to-exports ratio is projected to decline gradually from 100 to 91 percent during the projection period, reflecting mainly faster exports growth, with the NPV of debt remaining broadly stable. The public debt service-to-export ratio will also decline from 10 to 5 percent. The profile of the government and government-guaranteed (GGG) debt is largely similar to that of the public debt (Table 2).

11. The most optimistic scenario of conservative borrowing policies and the continuation of favorable recent macroeconomic trends would ease the debt burden

further. A historical scenario assumes the continuation of the favorable 2002-2004 trends in debt dynamics - key macroeconomic variables (real GDP growth, GDP deflator, non-interest current account and non-debt creating flows) at their 1998-2004 averages. Under this scenario, the NPV of public debt would decline from the baseline of 33 percent of GDP in 2004 to 24 percent in 2013, the NPV of debt-to export ratio will decline from 100 to 72 percent, and the debt service ratio will drop from 10 to 6 percent. (Table 3, Figure 1). In

\footnotetext{
${ }^{3}$ Debt sustainability in Low-Income Countries-Proposal for an Operational Framework and Policy Implications (www.imf.org).

${ }^{4}$ The coverage of public sector external debt in the external framework is slightly broader than in the fiscal framework. Compared to the former, the latter uses a concept of government and governmentguaranteed (GGG) external debt. Thus, it excludes debts of public enterprises not guaranteed by the government, which in Tajikistan is very small (about 2 percent of GDP).
} 
addition, if the primary fiscal deficit remains at the low level of 2002-2004 during the projection period, the NPV of debt-to-revenue ratio will decline from 175 percent in 2004 to 65 percent in 2013 and debt service-to-revenue ratio will drop to from 11 to 3 percent (Table 4, Figure 2) However, the economic factors that led to the recent rapid improvement in the debt outlook are not likely to be repeated.

12. Alternative less favorable scenarios suggest that the prospects of debt sustainability will depend critically on the continuation of sound policies and concessional borrowing. An extreme alternative scenario of a deterioration in all key variables by one-half standard deviation yields a significant deterioration of debt ratios. During the five years after such a shock, the NPV of public debt-to-GDP ratio may worsen by almost 50 percentage points on average, and a permanently lower GDP growth (by one standard deviation compared to the baseline) results in a deterioration in the NPV of debt-to-revenue ratio by 44 percentage points on average in 2005-2010. In the long run (Table 3 ), the scenario of less favorable

\begin{tabular}{|lrrrr|}
\hline \multicolumn{5}{|c|}{ Stress tests results, 2005-2010 averages } \\
& \multicolumn{5}{c|}{ The most extreme shock } \\
& Baseline & to exports to real GDP combined \\
NPV of debt-to-GDP & 29 & $\ldots$ & $\ldots$ & 78 \\
NPV of debt-to-exports & 93 & 169 & $\ldots$ & $\ldots$ \\
Debt service-to-exports & 7 & 11 & $\ldots$ & $\ldots$ \\
NPV of debt-to-revenue & 157 & $\ldots$ & 201 & $\ldots$ \\
Debt service-to-revenue & 12 & $\ldots$ & 14 & $\ldots$ \\
\hline
\end{tabular}
terms for new public sector borrowing (interest rate 2 percentage points higher than in the baseline) may result in a significant deterioration the NPV of debt-to-GDP ratio from 33 percent of GDP in 2004 to 48 percent in 2023 and in the NPV of debt-to-exports ratio from 100 to 137 percent. A permanently lower GDP growth is also a significant risk factor for fiscal debt sustainability in the long-term prospective (Table 4), as the associated lower revenue collection can result in an increase of NPV of debt-to-revenue ratio from 175 to 304 percent in 2004-2023, and the debt service-to-revenue ratio on GGG debt from 11 to 18 percent.

13. Additional bound tests show that Tajikistan's external public debt position will remain highly sensitive to adverse shocks. As just three commodities - aluminum, cotton, and fruits and vegetables - constitute some 40 percent of GDP, 70 percent of exports, and 10 percent of fiscal revenue, Tajikistan's debt sustainability in the long run will depend substantially on price and volume dynamics in these highly volatile sectors. Not surprisingly, an export revenue shock is one of the more extreme shock modeled by this DSA. In the medium term (see box above), assuming that export revenue declines by one standard deviation from its historical average, the NPV-to-exports ratio worsened from an average of 93 percent under the baseline in the next five years, to 169 percent in 2004-2010 on average, and the debt service ratio on public debt will deteriorate from 7 to 11 percent. In the longerterm prospective (Table 3 ), the debt dynamics are particularly sensitive to the export revenue shock. A one standard deviation shock compared to historical averages can lead to a protracted deterioration of the NPV of debt-to exports ratio, which will not disappear even by 2023. A surge in inflation and nominal depreciation are also important risk factors, which can have lasting effect on the NPV of debt-to-GDP and the fiscal ratios, in particular the 
NPV of debt-to-revenue and debt service-to-revenue ratios (Table 4). Therefore, if the forecast of the underlying GDP growth does not materialize, a permanently lower GDP growth is the most negative alternative scenario, which can have an adverse impact on the overall debt dynamics. Shocks to GDP and export growth, exchange rate depreciation and inflation are the most important risk factors for fiscal sustainability of the existing debt burden.

\section{Conclusions}

14. Tajikistan's debt situation seems sustainable, but vulnerable to shocks and hinges on continued strong policy implementation.

- External concessional borrowing not exceeding 4.5 percent of GDP annually is broadly consistent with long-term debt sustainability. Stability of debt ratios in the long run depends on cautious borrowing policies and strong macroeconomic performance. With strong growth underpinned by sustained reforms and no new nonconcessional borrowing, Tajikistan debt indicators are projected to remain stable in the longer term. However, slippages in reforms, lower growth, and adverse exogenous shocks, in particular to exports, are the largest sources of debt vulnerability.

- Fiscal sustainability of debt, although improved after the recent debt regularization agreements, needs to be monitored closely and continuously. Government's debt service obligations will remain an important expenditure item, in particular in the medium term. The revenue effort (taxes and grants) of at least 18.0-18.5 percent GDP during the forecast period and a fiscal deficit excluding the PIP not exceeding 0.5 percent of GDP are needed to target the debt service-to-revenue ratio at below 15 percent. This targeted level of debt service is appropriate based on historical experience and would permit additional budget expenditure on development and social needs, without diverting an excessive share to debt repayments. Lower GDP growth and revenue are the main risks to debt sustainability, as debt service payments could increase up to 20 percent of fiscal revenue in the worst case scenario.

- Restructuring of bilateral debt with large creditors remains a priority. Debt rescheduling or cancellation of obligations to the largest creditors (Uzbekistan, the United States, and Turkey) would help smoothen the debt profile in the medium term and reduce strain on fiscal resources.

- Strengthening debt management capacity must continue. The authorities need to establish a reliable computerized debt tracking system for all external debts - public and private - and start using it for budget and balance of payment forecasting and analysis. The terms and conditions of significant loans under the PIP or any other public credit line should be analyzed carefully to determine their impact on Tajikistan's debt profile and its sustainability. A fully-fledged DSA should be prepared annually, as a contribution to the annual budget exercise. 


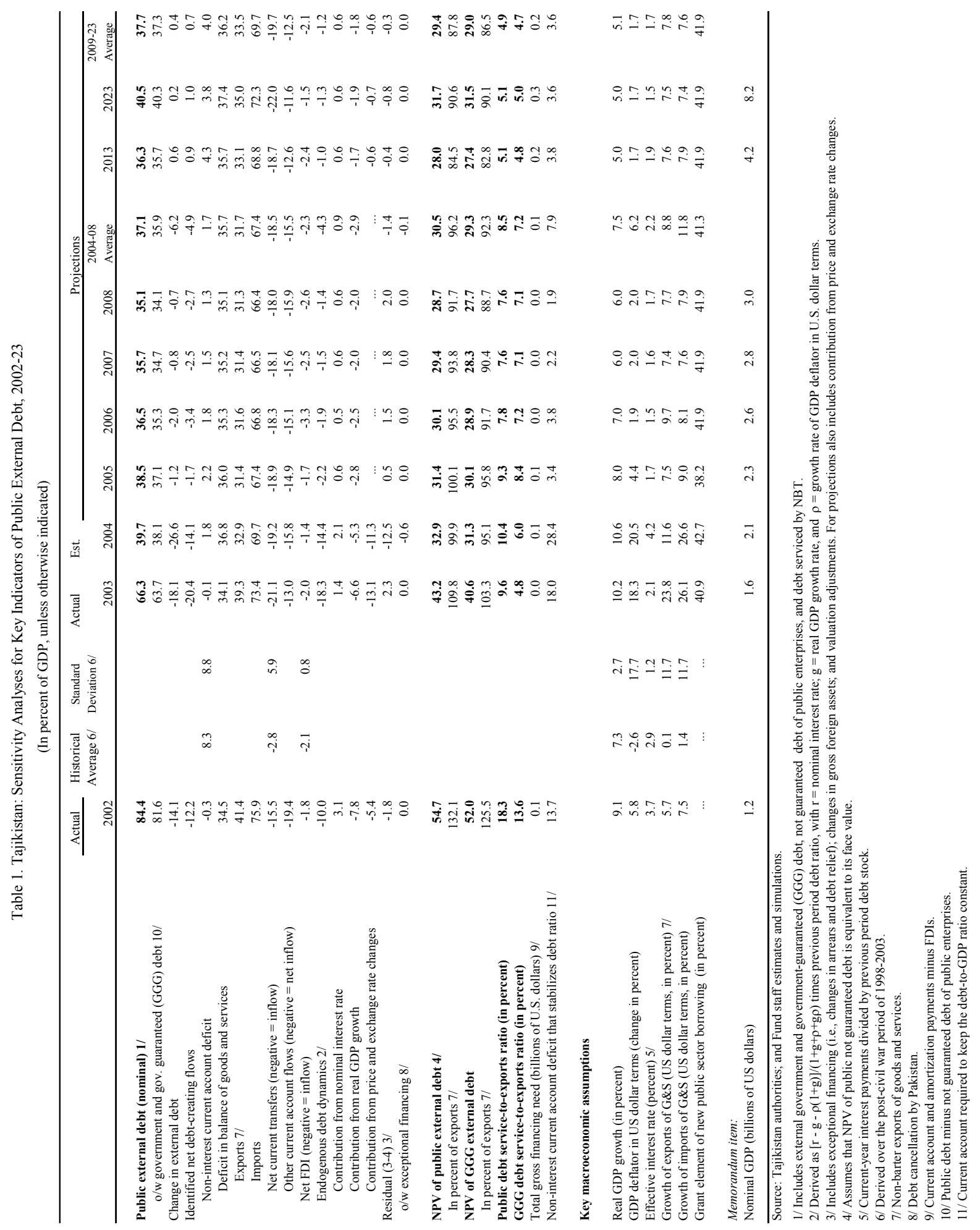




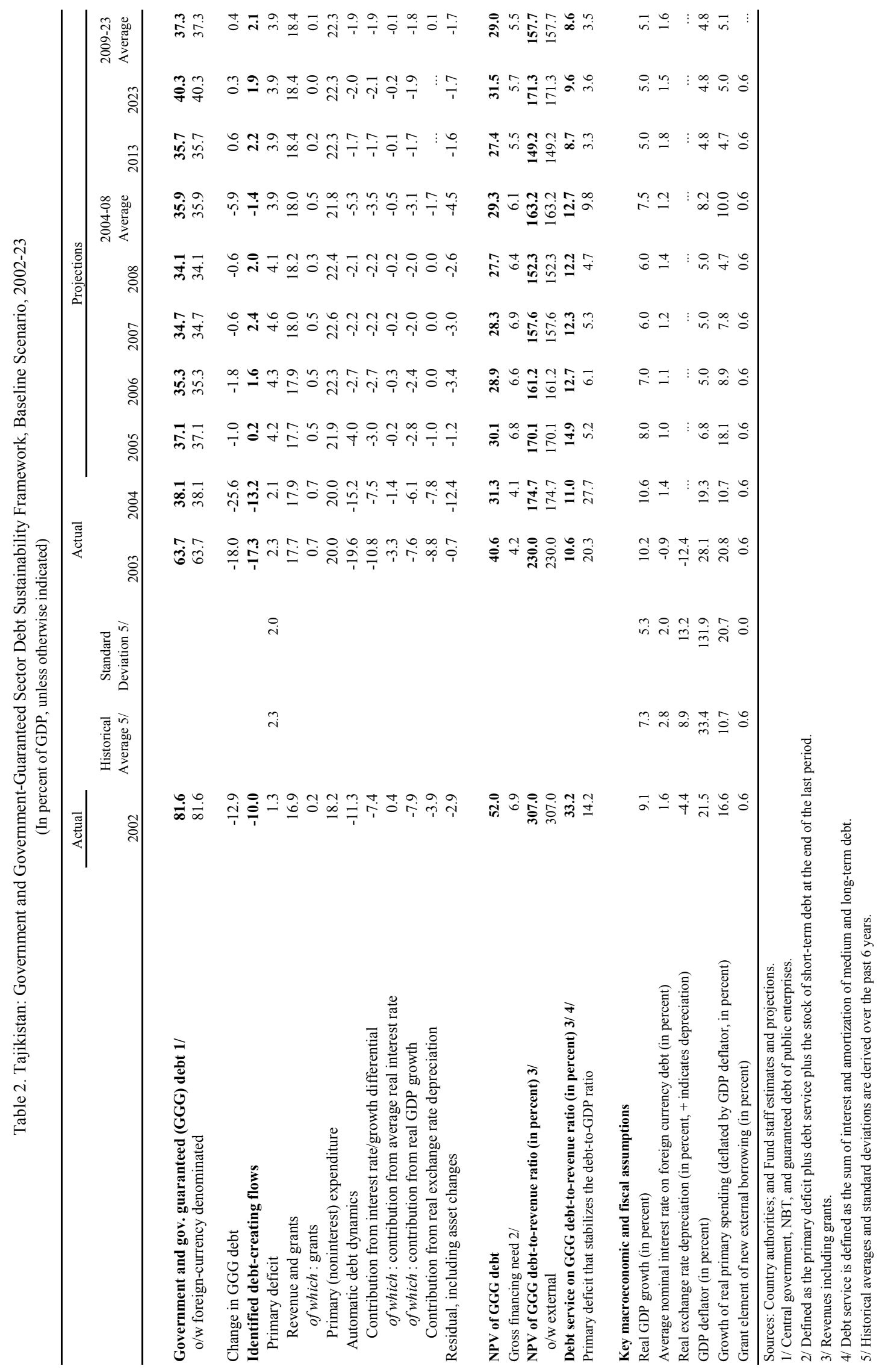


Table 3. Tajikistan: Sensitivity Analyses for Key Indicators of Public External Debt, 2003-23

(In percent)

\begin{tabular}{|c|c|c|c|c|c|c|c|c|}
\hline & \multirow{2}{*}{$\begin{array}{l}\text { Actual } \\
2003\end{array}$} & \multirow{2}{*}{$\begin{array}{l}\text { Est. } \\
2004\end{array}$} & \multicolumn{6}{|c|}{ Projections } \\
\hline & & & 2005 & 2006 & 2007 & 2008 & 2013 & 2023 \\
\hline \multicolumn{9}{|c|}{ NPV of debt-to-GDP ratio } \\
\hline Baseline & 43 & 33 & 31 & 30 & 29 & 29 & 28 & 32 \\
\hline \multicolumn{9}{|l|}{ A. Alternative Scenarios } \\
\hline A1. Key variables at their historical averages in 2004-23 1/ & 43 & 40 & 38 & 36 & 35 & 34 & 24 & 11 \\
\hline A2. New public sector loans on less favorable terms in $2004-232 /$ & 43 & 34 & 34 & 33 & 33 & 34 & 37 & 48 \\
\hline \multicolumn{9}{|l|}{ B. Bound Tests } \\
\hline B1. Real GDP growth at historical average minus one standard deviation in 2004-05 & 43 & 34 & 34 & 32 & 32 & 31 & 30 & 34 \\
\hline B2. Export value growth at historical average minus one standard deviation in 2004-05 3/ & 43 & 36 & 40 & 38 & 37 & 36 & 34 & 34 \\
\hline B3. US dollar GDP deflator at historical average minus one standard deviation in 2004-05 & 43 & 46 & 54 & 52 & 50 & 49 & 48 & 54 \\
\hline B4. Net non-debt creating flows at historical average minus one standard deviation in 2004-05 4/ & 43 & 46 & 57 & 55 & 53 & 51 & 45 & 38 \\
\hline B5. Combination of B1-B4 using one-half standard deviation shocks & 43 & 61 & 85 & 81 & 79 & 76 & 66 & 56 \\
\hline B6. One-time 30 percent nominal depreciation relative to the baseline in 20045 / & 43 & 44 & 42 & 40 & 39 & 38 & 37 & 42 \\
\hline \multicolumn{9}{|c|}{ NPV of debt-to-exports ratio } \\
\hline Baseline & 110 & 100 & 100 & 95 & 94 & 92 & 84 & 91 \\
\hline \multicolumn{9}{|l|}{ A. Alternative Scenarios } \\
\hline A1. Key variables at their historical averages in 2004-23 1/ & 110 & 122 & 122 & 116 & 111 & 107 & 72 & 31 \\
\hline A2. New public sector loans on less favorable terms in $2004-232 /$ & 110 & 104 & 107 & 105 & 107 & 108 & 113 & 137 \\
\hline \multicolumn{9}{|l|}{ B. Bound Tests } \\
\hline B1. Real GDP growth at historical average minus one standard deviation in 2004-05 & 110 & 100 & 100 & 95 & 94 & 92 & 84 & 91 \\
\hline B2. Export value growth at historical average minus one standard deviation in 2004-05 3/ & 110 & 134 & 182 & 173 & 170 & 166 & 145 & 138 \\
\hline B3. US dollar GDP deflator at historical average minus one standard deviation in 2004-05 & 110 & 100 & 100 & 95 & 94 & 92 & 84 & 91 \\
\hline B4. Net non-debt creating flows at historical average minus one standard deviation in 2004-05 4/ & 110 & 141 & 182 & 173 & 169 & 165 & 136 & 109 \\
\hline B5. Combination of B1-B4 using one-half standard deviation shocks & 110 & 158 & 228 & 216 & 211 & 206 & 170 & 135 \\
\hline B6. One-time 30 percent nominal depreciation relative to the baseline in 2004 5/ & 110 & 100 & 100 & 95 & 94 & 92 & 84 & 91 \\
\hline \multicolumn{9}{|c|}{ Debt service ratio } \\
\hline Baseline & 9.7 & 10.4 & 8.4 & 7.2 & 7.1 & 7.1 & 4.8 & 5.0 \\
\hline \multicolumn{9}{|l|}{ A. Alternative Scenarios } \\
\hline A1. Key variables at their historical averages in 2004-23 1/ & 9.7 & 14.5 & 11.4 & 9.1 & 8.6 & 8.5 & 5.6 & 2.2 \\
\hline A2. New public sector loans on less favorable terms in $2004-232 /$ & 9.7 & 12.2 & 9.7 & 8.4 & 8.4 & 8.6 & 7.6 & 8.7 \\
\hline \multicolumn{9}{|l|}{ B. Bound Tests } \\
\hline B1. Real GDP growth at historical average minus one standard deviation in 2004-05 & 9.7 & 12.2 & 9.4 & 7.8 & 7.6 & 7.8 & 6.3 & 5.2 \\
\hline B2. Export value growth at historical average minus one standard deviation in 2004-05 3/ & 9.7 & 14.8 & 13.8 & 11.9 & 11.5 & 11.8 & 11.0 & 8.4 \\
\hline B3. US dollar GDP deflator at historical average minus one standard deviation in 2004-05 & 9.7 & 12.2 & 9.4 & 7.8 & 7.6 & 7.8 & 6.3 & 5.2 \\
\hline B4. Net non-debt creating flows at historical average minus one standard deviation in 2004-05 4/ & 9.7 & 12.2 & 10.3 & 9.5 & 9.2 & 9.3 & 10.5 & 7.3 \\
\hline B5. Combination of B1-B4 using one-half standard deviation shocks & 9.7 & 13.8 & 12.7 & 11.8 & 11.4 & 11.5 & 13.1 & 9.0 \\
\hline B6. One-time 30 percent nominal depreciation relative to the baseline in 2004 5/ & 9.7 & 12.2 & 9.4 & 7.8 & 7.6 & 7.8 & 6.3 & 5.2 \\
\hline \multicolumn{9}{|l|}{ Memorandum item: } \\
\hline Grant element assumed on residual financing (i.e., financing required above baseline) 6/ & 41 & 41 & 41 & 41 & 41 & 41 & 41 & 41 \\
\hline
\end{tabular}

1/ Variables include real GDP growth, growth of GDP deflator (in U.S. dollar terms), non-interest current account in percent of GDP, and non-debt creating flows.

2/ Assumes that the interest rate on new borrowing is by 2 percentage points higher than in the baseline., while grace and maturity periods are the same as in the baseline

3/ Exports values are assumed to remain permanently at the lower level, but the current account as a share of GDP is assumed to return to its baseline level after the shock (implicitly assuming an offsetting adjustment in import levels).

4/ Includes official and private transfers and FDI

5/ Depreciation is defined as percentage decline in dollar/local currency rate, such that it never exceeds 100 percent.

6/ Applies to all stress scenarios except for A2 (less favorable financing) in which the terms on all new financing are as specified in footnote 2 . 
Table 4. Tajikistan: Sensitivity Analyses for Key Indicators of Government and Government Guaranteed Debt , 2003-23

\begin{tabular}{lll}
\hline & Actual Est. Projections
\end{tabular}

$2 0 0 3 2 0 0 4 \longdiv { 2 0 0 5 \quad 2 0 0 6 \quad 2 0 0 7 \quad 2 0 0 8 \quad 2 0 1 3 \quad 2 0 2 3 }$

\section{NPV of Debt-to-GDP Ratio}

\section{Baseline}

A. Alternative scenarios

A1. Real GDP growth and primary balance are at historical averages A2. Primary balance is unchanged from 2003

A3. Permanently lower GDP growth $1 /$

\section{B. Bound tests}

B1. Real GDP growth is at historical average minus one standard deviation in 2004-2005 B2. Primary balance is at historical average minus one standard deviation in 2004-2005

B3. Combination of B1-B2 using one half standard deviation shock

B4. One time 30 percent real depreciation in 2004

B5. 10 percent of GDP increase in other debt-creating flows in 2004

NPV of Debt-to-Revenue Ratio 2/

\section{Baseline}

\section{A. Alternative scenarios}

A1. Real GDP growth and primary balance are at historical averages

A2. Primary balance is unchanged from 2003

A3. Permanently lower GDP growth $1 /$

\section{B. Bound tests}

B1. Real GDP growth is at historical average minus one standard deviations in 2004-2005 B2. Primary balance is at historical average minus one standard deviations in 2004-2005

B3. Combination of B1-B2 using one half standard deviation shocks

B4. One time 30 percent real depreciation in 2004

B5. 10 percent of GDP increase in other debt-creating flows in 2004

\section{Debt Service-to-Revenue Ratio 2/}

\section{Baseline}

\section{A. Alternative scenarios}

A1. Real GDP growth and primary balance are at historical averages

A2. Primary balance is unchanged from 2003

A3. Permanently lower GDP growth 1/

\section{B. Bound tests}

B1. Real GDP growth is at historical average minus one standard deviations in 2004-2005 B2. Primary balance is at historical average minus one standard deviations in 2004-2005

B3. Combination of B1-B2 using one half standard deviation shocks

B4. One time 30 percent real depreciation in 2004

B5. 10 percent of GDP increase in other debt-creating flows in 2004

\section{Debt Service-to-GDP Ratio}

\section{Baseline}

\section{A. Alternative scenarios}

A1. Real GDP growth and primary balance are at historical averages

A2. Primary balance is unchanged from 2003

A3. Permanently lower GDP growth 1/

\section{B. Bound tests}

B1. Real GDP growth is at historical average minus one standard deviations in 2004-2005 B2. Primary balance is at historical average minus one standard deviations in 2004-2005 B3. Combination of B1-B2 using one half standard deviation shocks B4. One time 30 percent real depreciation in 2004

B5. 10 percent of GDP increase in other debt-creating flows in 2004

$\begin{array}{rrrrrrrr}41 & 31 & 30 & 29 & 28 & 28 & 27 & 31 \\ & & & & & & & \\ 41 & 32 & 29 & 26 & 23 & 20 & 12 & 7 \\ 41 & 31 & 28 & 24 & 22 & 19 & 14 & 13 \\ 41 & 32 & 31 & 30 & 30 & 30 & 34 & 56\end{array}$

$\begin{array}{llllllll}41 & 34 & 35 & 36 & 36 & 37 & 44 & 61\end{array}$

$\begin{array}{llllllll}41 & 34 & 32 & 31 & 30 & 30 & 29 & 33\end{array}$

$\begin{array}{llllllll}41 & 34 & 32 & 30 & 29 & 29 & 27 & 29\end{array}$

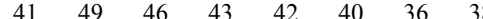

$\begin{array}{llllllll}41 & 41 & 40 & 38 & 37 & 36 & 35 & 38\end{array}$

$\begin{array}{llllllll}230 & 175 & 170 & 161 & 158 & 152 & 149 & 171\end{array}$

$\begin{array}{llllllll}230 & 181 & 165 & 144 & 126 & 110 & 65 & 38\end{array}$

$\begin{array}{rrrrrrrr}230 & 175 & 157 & 136 & 120 & 107 & 75 & 69\end{array}$

$\begin{array}{llllllll}230 & 176 & 174 & 167 & 166 & 164 & 187 & 304\end{array}$

$\begin{array}{llllllll}230 & 190 & 199 & 198 & 202 & 204 & 239 & 331\end{array}$

$\begin{array}{llllllll}230 & 187 & 183 & 173 & 169 & 164 & 159 & 178\end{array}$

$\begin{array}{lllllllll}230 & 188 & 180 & 169 & 164 & 157 & 147 & 159\end{array}$

$\begin{array}{llllllll}230 & 274 & 257 & 241 & 231 & 219 & 195 & 207\end{array}$

$\begin{array}{llllllll}230 & 230 & 224 & 212 & 207 & 200 & 191 & 204\end{array}$

$\begin{array}{llllllll}10.6 & 11.0 & 14.9 & 12.7 & 12.3 & 12.2 & 8.7 & 9.6\end{array}$

$\begin{array}{llllllll}10.6 & 11.4 & 15.5 & 12.4 & 11.0 & 9.9 & 3.3 & 0.8\end{array}$

$\begin{array}{llllllll}10.6 & 11.0 & 14.9 & 12.7 & 12.3 & 12.2 & 8.7 & 9.6\end{array}$

$\begin{array}{llllllll}10.6 & 11.1 & 15.1 & 13.1 & 12.8 & 13.0 & 10.9 & 17.7\end{array}$

$\begin{array}{llllllll}10.6 & 11.7 & 16.7 & 14.9 & 15.0 & 15.5 & 14.3 & 20.0\end{array}$

$\begin{array}{llllllll}10.6 & 11.0 & 16.0 & 13.6 & 13.2 & 13.1 & 9.4 & 9.9\end{array}$

$\begin{array}{lllllllll}10.6 & 11.5 & 16.4 & 13.5 & 13.0 & 12.7 & 8.5 & 8.5\end{array}$

$\begin{array}{llllllll}10.6 & 11.8 & 15.7 & 13.7 & 13.4 & 13.5 & 10.5 & 11.9\end{array}$

$\begin{array}{llllllll}10.6 & 11.0 & 19.7 & 16.5 & 16.0 & 15.7 & 11.7 & 11.8\end{array}$

Sources: Country authorities; and Fund staff estimates and projections.

1/ Assumes that real GDP growth is at baseline minus one standard deviation divided by the square root of 20 (i.e., the length of the projection period)

$2 /$ Revenues are defined inclusive of grants. 
Fïgure 1. Tajikistan: Indicators of Public External Debt

Under Alternative Scenarios, 2003-2023

(In percent)
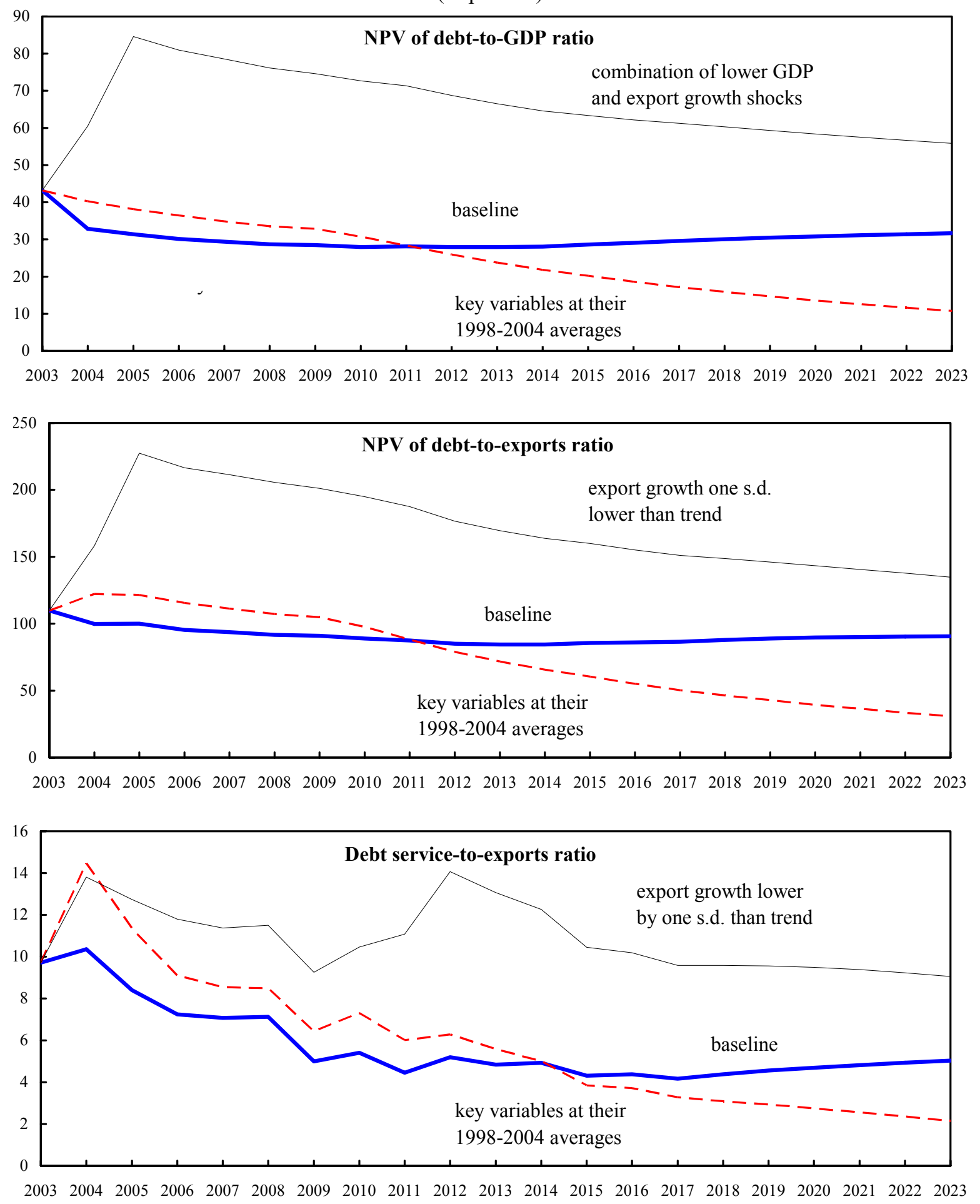

Source: Staff projections and simulations. 
Figure 2. Tajikistan: Indicators of Government and Government-Guaranteed Debt Under Alternative Scenarios, 2003-23 1/ (In percent)
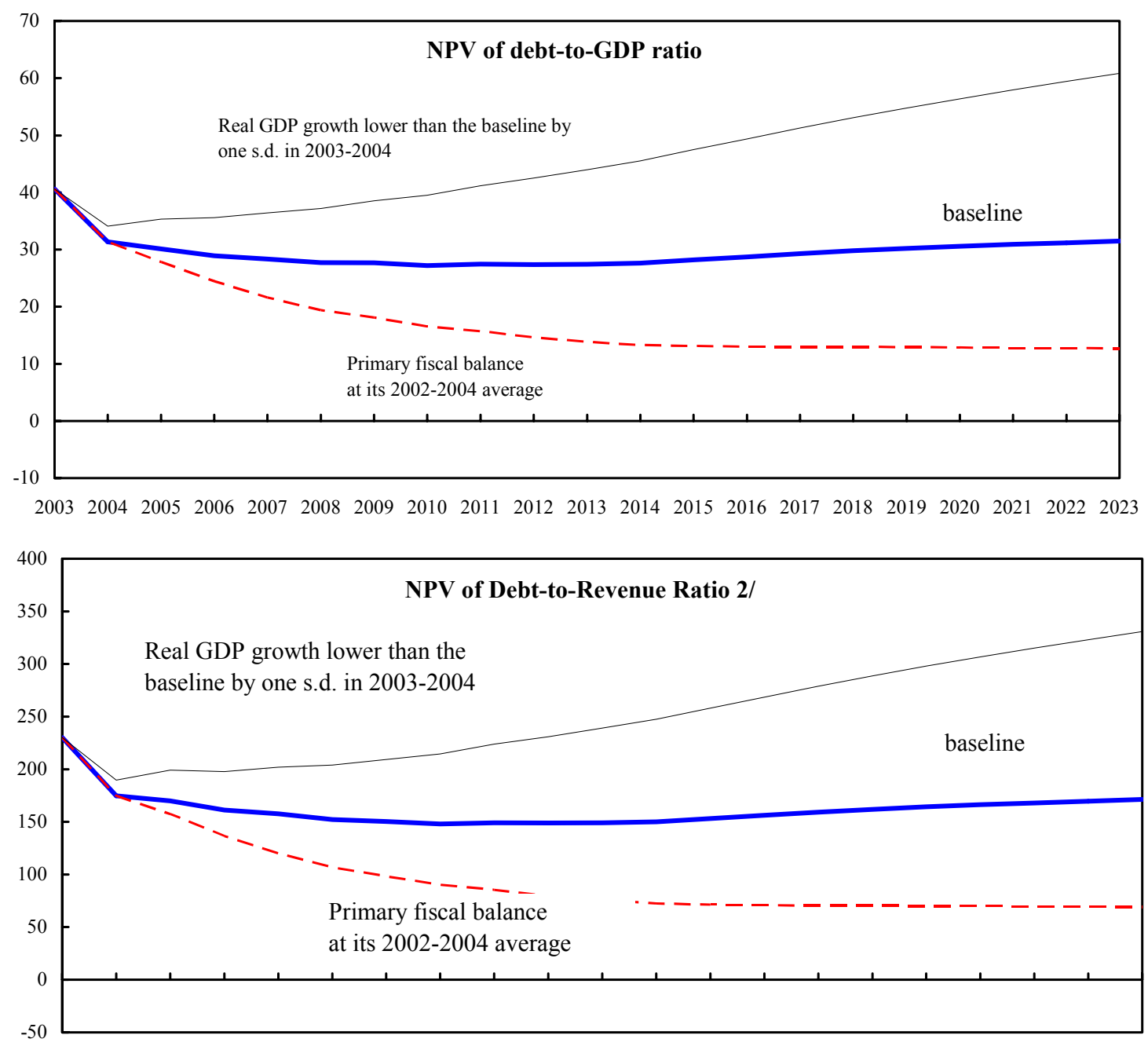

$20032004200520062007200820092010201120122013201420152016201720182019202020212022 \quad 2023$

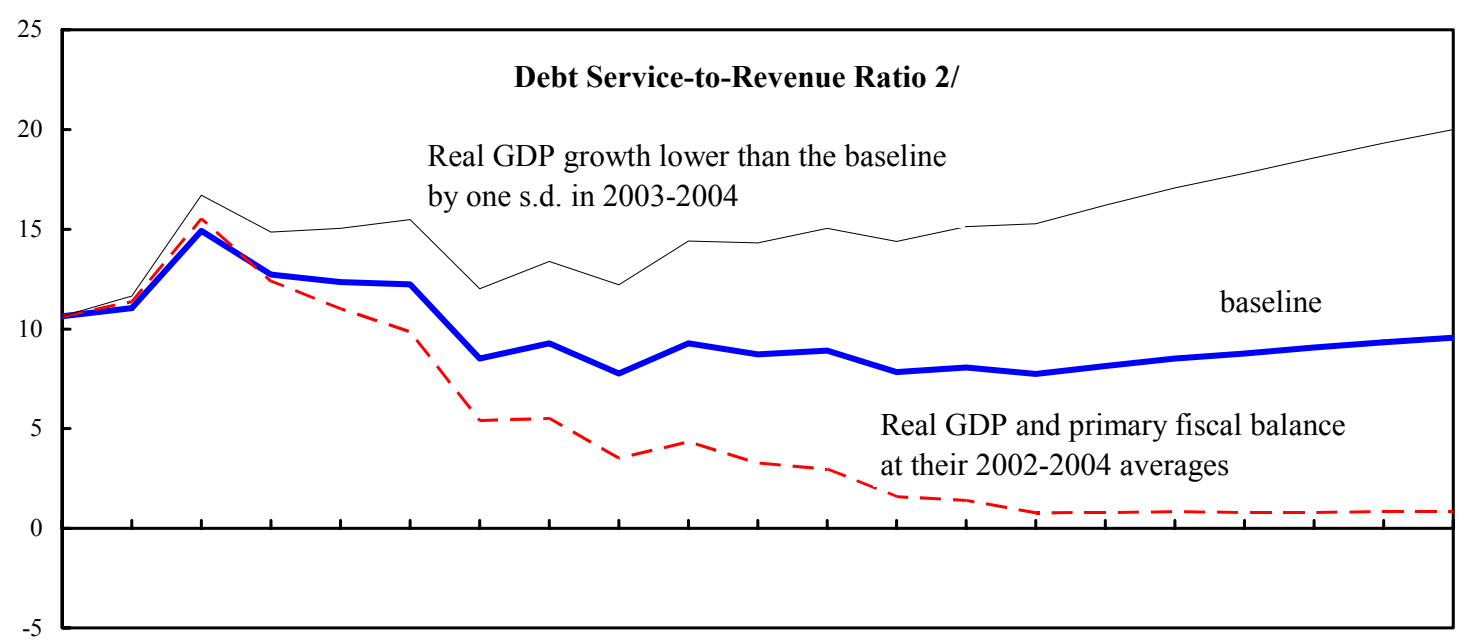

$2003200420052006200720082009201020112012 \quad 2013201420152016201720182019202020212022 \quad 2023$

Source: Staff projections and simulations.

1/ Most extreme stress test is test that yields highest ratio in 2013.

2/ Revenue including grants. 
Table A-1. Tajikistan: Basic Economic Data, 2000-04

\begin{tabular}{|c|c|c|c|c|c|}
\hline \multicolumn{6}{|l|}{ Demographic indicators } \\
\hline Area (2002) & \multicolumn{5}{|c|}{$143,100 \mathrm{~km}^{2}$} \\
\hline Arable land (2002) & \multicolumn{5}{|c|}{$7,155 \mathrm{~km}^{2}$} \\
\hline Population as of Dec 31, 2004 (in thousand) & \multicolumn{5}{|c|}{6,732} \\
\hline Rate of population growth (in percent) & \multicolumn{5}{|c|}{1.9} \\
\hline Life expectancy at birth (1998) & \multicolumn{5}{|c|}{66.9} \\
\hline Men & \multicolumn{5}{|c|}{64.3} \\
\hline Women & \multicolumn{5}{|c|}{69.7} \\
\hline Infant mortality rate (per 1,000 births, 1999) & \multicolumn{5}{|c|}{36.7} \\
\hline Hospital beds (per 10,000 inhabitants, 2002) & \multicolumn{5}{|c|}{62.2} \\
\hline \multirow[t]{3}{*}{ Physicians (per 10,000 inhabitants, 2002) } & \multicolumn{5}{|c|}{20.1} \\
\hline & 2000 & 2001 & 2002 & 2003 & 2004 \\
\hline & & & & & Prel. \\
\hline Nominal GDP (in millions of somoni) & 1,807 & 2,512 & 3,345 & 4,758 & 6,158 \\
\hline Real GDP growth (in percent) & 8.3 & 10.2 & 9.1 & 10.2 & 10.6 \\
\hline Inflation (in percent, end of period) & 60.6 & 12.5 & 14.5 & 13.7 & 5.6 \\
\hline \multirow[t]{2}{*}{ Inflation (in percent, average) } & 32.9 & 38.6 & 10.2 & 17.1 & 7.1 \\
\hline & \multicolumn{5}{|c|}{ (In percent of GDP) } \\
\hline \multicolumn{6}{|l|}{ Sectoral distribution of GDP } \\
\hline Agriculture & 27.0 & 26.5 & 26.3 & 25.2 & 21.6 \\
\hline Industry & 23.9 & 22.7 & 22.1 & 20.9 & 19.6 \\
\hline Trade & 18.3 & 19.1 & 19.9 & 19.0 & 19.7 \\
\hline Construction & 3.4 & 4.1 & 3.8 & 4.2 & 5.5 \\
\hline Other & 27.4 & 27.6 & 27.9 & 30.7 & 33.6 \\
\hline \multicolumn{6}{|l|}{ Balance of payments } \\
\hline Current account balance (In percent of GDP) & -6.5 & -6.7 & -2.7 & -1.3 & -3.9 \\
\hline Gross official reserves (in months of imports) & 2.1 & 1.9 & 1.8 & 1.8 & 2.0 \\
\hline & \multicolumn{5}{|c|}{ (In percent of GDP) } \\
\hline \multicolumn{6}{|l|}{ Consolidated government finances } \\
\hline Revenue & 13.9 & 15.1 & 16.7 & 17.3 & 17.9 \\
\hline Expenditure 1/ & 15.2 & 16.3 & 16.8 & 16.4 & 17.6 \\
\hline Overall balance $1 /$ & -1.3 & -1.1 & -0.1 & 0.9 & 0.3 \\
\hline & \multicolumn{5}{|c|}{ (Percent change from previous period) } \\
\hline \multicolumn{6}{|l|}{ Money and credit } \\
\hline Somoni broad money & 78.2 & 40.0 & 39.7 & 29.2 & 14.3 \\
\hline Credit to private sector & 90.2 & 54.3 & 20.2 & 10.9 & 57.9 \\
\hline Interest rate $2 /$ & 34.4 & 18.5 & 23.1 & 4.9 & 6.2 \\
\hline
\end{tabular}

Source: Tajik authorities.

1/ Excludes externally-financed public investment program.

2/ Lending rate for domestic currency denominated 3-6 months loans; end of year. 
Table A-2. Tajikistan: Nominal and Real GDP, 2000-04 1/

\begin{tabular}{|c|c|c|c|c|}
\hline & & $\begin{array}{c}\text { Nominal GDP } \\
\text { (In millions of somoni) }\end{array}$ & $\begin{array}{c}\text { Real GDP } \\
\text { (Index, 2000=100) }\end{array}$ & $\begin{array}{l}\text { Percent change } \\
\text { of real GDP }\end{array}$ \\
\hline & & & & (Over the previous year) \\
\hline & 2000 & 1,807 & 100.0 & 8.3 \\
\hline & 2001 & 2,512 & 110.2 & 10.2 \\
\hline & 2002 & 3,345 & 120.2 & 9.1 \\
\hline & 2003 & 4,758 & 132.5 & 10.2 \\
\hline & 2004 & 6,158 & 146.5 & 10.6 \\
\hline \multirow{5}{*}{2000} & & & & $\begin{array}{l}\text { (Over same quarter } \\
\text { of the previous year) }\end{array}$ \\
\hline & Q1 & 243 & 14.9 & 3.8 \\
\hline & Q2 & 306 & 19.7 & 2.6 \\
\hline & Q3 & 555 & 33.1 & 20.2 \\
\hline & Q4 & 702 & 32.4 & 3.4 \\
\hline \multirow[t]{4}{*}{2001} & Q1 & 401 & 16.0 & 7.6 \\
\hline & Q2 & 490 & 22.1 & 12.3 \\
\hline & Q3 & 757 & 36.9 & 11.5 \\
\hline & Q4 & 864 & 35.2 & 8.7 \\
\hline \multirow[t]{4}{*}{2002} & Q1 & 508 & 17.5 & 9.3 \\
\hline & Q2 & 686 & 23.7 & 7.5 \\
\hline & Q3 & 979 & 40.5 & 9.8 \\
\hline & Q4 & 1,171 & 38.5 & 9.3 \\
\hline \multirow[t]{4}{*}{2003} & Q1 & 755 & 19.6 & 12.1 \\
\hline & Q2 & 1,039 & 25.2 & 6.0 \\
\hline & Q3 & 1,374 & 43.4 & 7.2 \\
\hline & Q4 & 1,590 & 44.3 & 15.1 \\
\hline \multirow[t]{4}{*}{2004} & Q1 & 1,123 & 21.4 & 9.1 \\
\hline & Q2 & 1,231 & 28.3 & 12.7 \\
\hline & Q3 & 1,886 & 49.7 & 14.6 \\
\hline & Q4 & 1,917 & 47.0 & 6.2 \\
\hline
\end{tabular}

Source: State Statistical Committee.

1/ The data for 2004 are preliminary. 


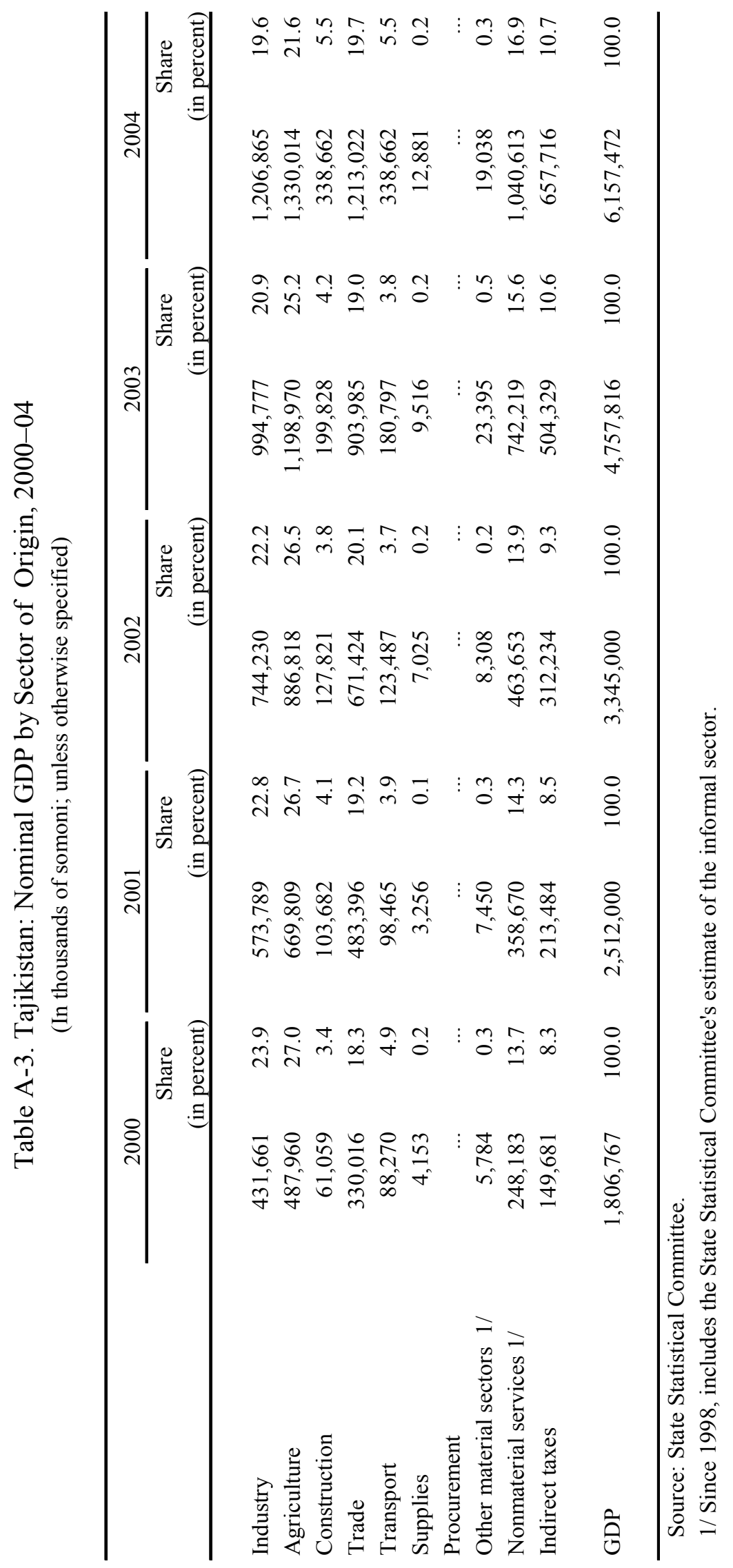


Table A-4. Tajikistan: Production and Yields of Major Agricultural Crops, 2000-04

\begin{tabular}{|c|c|c|c|c|c|}
\hline & 2000 & 2001 & 2002 & 2003 & 2004 \\
\hline \multirow{3}{*}{ Crop production } & \multicolumn{5}{|c|}{ (In thousands of somoni at constant 2000 prices) } \\
\hline & 594,192 & 642,143 & 753,683 & 828,184 & 959,037 \\
\hline & \multicolumn{5}{|c|}{ (In thousands of tons) } \\
\hline \multicolumn{6}{|l|}{ Production } \\
\hline \multicolumn{6}{|l|}{ Of which: } \\
\hline Raw cotton & 335 & 453 & 515 & 537 & 557 \\
\hline Grain & 550 & 494 & 596 & 730 & 734 \\
\hline Sweet corn & 38 & 42 & 55 & 95 & 95 \\
\hline Feed corn & 226 & 241 & 299 & 294 & 295 \\
\hline Rice & 82 & 39 & 50 & 59 & 59 \\
\hline Potatoes & 303 & 308 & 357 & 473 & 527 \\
\hline Vegetables & 354 & 397 & 473 & 583 & 679 \\
\hline Fruits & 169 & 144 & 147 & 89 & 144 \\
\hline Grapes & 110 & 110 & 81 & 28 & 93 \\
\hline Hay & 290 & 275 & 376 & 356 & 443 \\
\hline & \multicolumn{5}{|c|}{ (In kilograms per hectare) } \\
\hline \multicolumn{6}{|l|}{ Yield } \\
\hline \multicolumn{6}{|l|}{ Of which: } \\
\hline Raw cotton & 1,410 & 1,790 & 1,930 & 1,900 & 1,910 \\
\hline Grain & 1,270 & 1,430 & 1,820 & 1,990 & 1,970 \\
\hline Sweet corn & 2,700 & 2,950 & 3,510 & 3,770 & 3,540 \\
\hline Feed corn & 10,250 & 11,750 & 13,080 & 14,800 & 14,223 \\
\hline Rice & 3,790 & 2,610 & 2,850 & 3,460 & 3,000 \\
\hline Potatoes & 11,870 & 12,550 & 15,550 & 17,740 & 17,400 \\
\hline Vegetables & 11,370 & 11,710 & 13,890 & 16,200 & 18,300 \\
\hline Fruits & 2,420 & 2,490 & 2,470 & 1,520 & 2,400 \\
\hline Grapes & 3,270 & 3,290 & 2,460 & 950 & 3,100 \\
\hline Hay & 1,714 & 1,010 & 1,430 & 1,360 & 2,060 \\
\hline
\end{tabular}

Source: State Statistical Committee. 
Table A-5. Tajikistan: Animal Husbandry, 2000-04

\begin{tabular}{|c|c|c|c|c|c|}
\hline & 2000 & 2001 & 2002 & 2003 & 2004 \\
\hline & \multicolumn{5}{|c|}{ (In thousands of somoni at constant 2000 prices) } \\
\hline \multirow[t]{2}{*}{ Animal husbandry } & 121,611 & 143,461 & 156,838 & 169,747 & 203,187 \\
\hline & \multicolumn{5}{|c|}{ (In thousands) } \\
\hline Total production & 3,357 & 3,432 & 3,643 & 3,886 & 4,113 \\
\hline \multicolumn{6}{|l|}{ Of which: } \\
\hline Beef cattle & 510 & 532 & 549 & 583 & 636 \\
\hline Milk cows & 552 & 559 & 587 & 636 & 642 \\
\hline Pigs & 1 & 1 & 1 & 1 & 1 \\
\hline Sheep & 1,478 & 1,490 & 1,591 & 1,672 & 1,782 \\
\hline Goats & 744 & 779 & 842 & 920 & 975 \\
\hline Horses & 72 & 71 & 73 & 74 & 77 \\
\hline
\end{tabular}

Source: State Statistical Committee. 
Table A-6. Tajikistan: Agricultural Production by Type of Farm, 2000-04

\begin{tabular}{|c|c|c|c|c|c|}
\hline & 2000 & 2001 & 2002 & 2003 & $\begin{array}{r}\text { Jan-Sep. } \\
2004 \\
\end{array}$ \\
\hline & \multicolumn{5}{|c|}{ (In thousands of somoni at 2000 prices) } \\
\hline Total for all types of farms & 715,803 & 785,604 & 910,525 & $1,001,995$ & $1,171,571$ \\
\hline & \multicolumn{5}{|c|}{ (In percent) } \\
\hline Total for all types of farms & 100.0 & 100.0 & 100.0 & 100.0 & 100.0 \\
\hline \multicolumn{6}{|l|}{ Of which: } \\
\hline Crop production & 83.0 & 81.7 & 82.8 & 83.0 & 81.0 \\
\hline Animal husbandry & 17.0 & 18.3 & 17.2 & 17.0 & 19.0 \\
\hline State and collective farms & 36.2 & 32.7 & 32.4 & 48.0 & 24.9 \\
\hline \multicolumn{6}{|l|}{ Of which: } \\
\hline Crop production & 95.0 & 96.2 & 96.6 & 97.0 & 95.6 \\
\hline Animal husbandry & 5.0 & 3.8 & 3.4 & 3.0 & 4.4 \\
\hline Personal lots & 63.8 & 67.3 & 67.6 & 52.0 & 75.1 \\
\hline \multicolumn{6}{|l|}{ Of which: } \\
\hline Crop production & 85.0 & 74.7 & 76.1 & 60.0 & 76.1 \\
\hline Animal husbandry & 15.0 & 25.3 & 23.9 & 40.0 & 23.9 \\
\hline
\end{tabular}

Source: State Statistical Committee. 
Table A-7. Tajikistan: Allocation of Agricultural Land, 2004

\begin{tabular}{|c|c|c|c|c|}
\hline & Total & $\begin{array}{l}\text { Collective and } \\
\text { Other Farms } 1 /\end{array}$ & $\begin{array}{r}\text { Private Farms } \\
\text { and Employees }\end{array}$ & Other $2 /$ \\
\hline & \multicolumn{4}{|c|}{ (In hectares) } \\
\hline $\begin{array}{l}\text { Total crops } \\
\text { Of which. }\end{array}$ & 886,864 & 451,815 & 240,132 & 194,917 \\
\hline Irrigated land & 592,006 & 328,997 & 167,158 & 95,851 \\
\hline $\begin{array}{l}\text { Winter crops } \\
\text { Of which: }\end{array}$ & 187,215 & 61,081 & 36,245 & 89,889 \\
\hline Winter wheat & 177,050 & 56,695 & 34,519 & 85,836 \\
\hline Rye & 248 & 220 & 28 & 0 \\
\hline Barley & 9,917 & 4,166 & 1,698 & 4,053 \\
\hline $\begin{array}{l}\text { Spring crops } \\
\text { Of which: }\end{array}$ & 209,113 & 96,630 & 68,698 & 43,785 \\
\hline Wheat & 157,816 & 73,001 & 51,411 & 33,404 \\
\hline Barley & 27,570 & 13,722 & 10,015 & 3,833 \\
\hline Maize & 8,320 & 2,714 & 923 & 4,683 \\
\hline Rice & 11,394 & 6,362 & 2,544 & 2,488 \\
\hline Oats & 681 & 565 & 116 & $\ldots$ \\
\hline Other grains and beans & 11,652 & 2,980 & 4,612 & 4,060 \\
\hline Cotton & 284,367 & 200,178 & 84,189 & 0 \\
\hline Flax & 21,108 & 6,162 & 8,581 & 6,365 \\
\hline Tobacco & 795 & 471 & 246 & 78 \\
\hline Potatoes & 25,988 & 2,966 & 5,395 & 17,627 \\
\hline Vegetables & 30,299 & 5,505 & 3,812 & 20,912 \\
\hline Fodder & 96,098 & 65,118 & 23,556 & 7,424 \\
\hline Melons and gourds & 10,671 & 3,817 & 3,500 & 3,347 \\
\hline Other industrial crops & 12,867 & 6,919 & 5,439 & 119 \\
\hline Seed trees of vegetables and melons & \multicolumn{4}{|c|}{ (In percent of total) } \\
\hline $\begin{array}{l}\text { Total crops } \\
\text { Of which: }\end{array}$ & 100.0 & 50.9 & 27.1 & 22.0 \\
\hline Irrigated land & 66.8 & 37.1 & 18.8 & 10.8 \\
\hline $\begin{array}{l}\text { Winter crops } \\
\text { Of which: }\end{array}$ & 21.1 & 6.9 & 4.1 & 10.1 \\
\hline Winter wheat & 20.0 & 6.4 & 3.9 & 9.7 \\
\hline Rye & 0.0 & 0.0 & 0.0 & $\ldots$ \\
\hline Barley & 1.1 & 0.5 & 0.2 & 0.5 \\
\hline Spring crops & 23.6 & 10.9 & 7.7 & 4.9 \\
\hline Of which: & 0.0 & 0.0 & 0.0 & 0.0 \\
\hline Wheat & 17.8 & 8.2 & 5.8 & 3.8 \\
\hline Barley & 3.1 & 1.5 & 1.1 & 0.4 \\
\hline Maize & 0.9 & 0.3 & 0.1 & 0.5 \\
\hline Rice & 1.3 & 0.7 & 0.3 & 0.3 \\
\hline Oats & 0.1 & 0.1 & 0.0 & $\ldots$ \\
\hline Grains and beans & 1.3 & 0.3 & 0.5 & 0.5 \\
\hline Other grains and beans & 1.3 & 0.3 & 0.5 & 0.5 \\
\hline Other cereals & 3.7 & 1.7 & 1.5 & 0.5 \\
\hline Cotton & 32.1 & 22.6 & 9.5 & $\ldots$ \\
\hline Flax & 2.4 & 0.7 & 1.0 & 0.7 \\
\hline Tobacco & 0.1 & 0.1 & 0.0 & 0.0 \\
\hline Potatoes & 2.9 & 0.3 & 0.6 & 2.0 \\
\hline Vegetables & 3.4 & 0.6 & 0.4 & 2.4 \\
\hline Fodder & 10.8 & 7.3 & 2.7 & 0.8 \\
\hline Melons and gourds & 1.2 & 0.4 & 0.4 & 0.4 \\
\hline Other industrial crops & 1.5 & 0.8 & 0.6 & 0.0 \\
\hline Seed trees of vegetables and melons & 0.0 & 0.0 & 0.0 & 0.0 \\
\hline
\end{tabular}

Source: State Statistical Committee.

1/ Includes collective farms (kolkhozes), state farms (sovkhozes), state farms in transformation to collective farms (mezhozes), and other farms.

2/ Personal plots, including 75,000 hectares of land distributed by presidential decree in 1997 . 
Table A-8. Tajikistan: Industrial Output by Sector at Constant Prices, 2000-04

\begin{tabular}{|c|c|c|c|c|c|}
\hline & 2000 & 2001 & 2002 & 2003 & $\begin{array}{r}2004 \\
\text { Prel }\end{array}$ \\
\hline & \multicolumn{5}{|c|}{ (In millions of somoni at 1998 prices) } \\
\hline Total industry & 710,482 & 817,054 & 885,686 & 973,369 & $1,112,561$ \\
\hline & \multicolumn{5}{|c|}{ (In percent) } \\
\hline \multicolumn{6}{|l|}{$\begin{array}{l}\text { Share in total industrial output } \\
\text { Of which: }\end{array}$} \\
\hline Electric energy & 7.2 & 6.6 & 5.8 & 7.5 & 6.0 \\
\hline Fuel, refinery & 0.2 & 0.2 & 0.2 & 0.2 & 0.3 \\
\hline Nonferrous metallurgy & 56.3 & 54.2 & 48.9 & 44.6 & 47.2 \\
\hline Chemical and petrochemical & 1.7 & 1.2 & 0.9 & 1.1 & 1.3 \\
\hline $\begin{array}{l}\text { Mechanical engineering } \\
\text { and metal working }\end{array}$ & 0.9 & 0.7 & 0.9 & 1.0 & 1.6 \\
\hline Wood and wood-working, paper & 0.0 & 0.0 & 0.1 & 0.1 & 0.2 \\
\hline Glass & 0.3 & 0.4 & 0.4 & 0.3 & 0.2 \\
\hline Construction material & 0.8 & 0.7 & 1.1 & 1.4 & 1.5 \\
\hline Light industry & 15.5 & 12.7 & 17.8 & 21.7 & 17.8 \\
\hline Food & 10.7 & 16.9 & 17.9 & 15.4 & 15.0 \\
\hline Flour grinding & 6.1 & 6.3 & 5.8 & 6.5 & 8.7 \\
\hline Unallocated & 0.3 & 0.1 & 0.2 & 0.2 & 0.2 \\
\hline & \multicolumn{5}{|c|}{ (Index 1990=100) } \\
\hline Total industry & 40.6 & 46.7 & 50.6 & 55.6 & 63.6 \\
\hline Of which: & & & & & \\
\hline Electric energy & 107.4 & 111.3 & 119.8 & 127.7 & 127.8 \\
\hline Fuel, refinery & 7.9 & 8.7 & 11.5 & 13.9 & 17.4 \\
\hline Nonferrous metallurgy & 59.4 & 66.3 & 69.8 & 72.7 & 82.4 \\
\hline Chemical and petrochemical & 10.5 & 8.8 & 8.9 & 13.8 & 21.4 \\
\hline $\begin{array}{l}\text { Mechanical engineering } \\
\text { and metal working }\end{array}$ & 14.7 & 17.7 & 23.8 & 31.5 & 69.5 \\
\hline Wood and wood-working, paper & 5.1 & 7.6 & 9.4 & 13.0 & 26.6 \\
\hline Glass & 26.5 & 42.5 & 45.4 & 41.3 & 45.8 \\
\hline Construction material & 3.6 & 4.2 & 5.6 & 8.5 & 9.9 \\
\hline Light industry & 35.7 & 37.7 & 47.1 & 55.5 & 61.8 \\
\hline Food & 16.8 & 25.3 & 26.0 & 26.8 & 31.2 \\
\hline Flour grinding & 34.4 & 37.9 & 38.6 & 53.2 & 62.3 \\
\hline
\end{tabular}

Source: State Statistical Committee. 
Table A-9. Tajikistan: Selected Indicators of Industrial Production, 2000-04

\begin{tabular}{|c|c|c|c|c|c|}
\hline & 2000 & 2001 & 2002 & 2003 & 2004 \\
\hline High-capacity electrical transformers (in thousand $\mathrm{kWh}$ ) & 37.4 & 61.2 & 58.9 & 63.9 & 78.8 \\
\hline Aluminum (in thousand tons) & 269.2 & 289.1 & 307.6 & 319.4 & 358.3 \\
\hline Cement (in thousand tons) & 54.8 & 68.9 & 89.2 & 166.3 & 193.6 \\
\hline \multicolumn{6}{|l|}{ Prefabricated reinforced concrete } \\
\hline construction elements (in thousand cubic meters) & 12.5 & 12.0 & 16.5 & 17.0 & 18.3 \\
\hline Construction bricks (in million units) & 29.9 & 23.9 & 29.2 & 32.5 & 39.5 \\
\hline Asbestos-roofing (in million sheets) & 2.3 & 1.0 & 2.2 & 2.9 & 0.6 \\
\hline Lumber/Timber (in thousand cubic meters) & 0.1 & 0.2 & $\ldots$ & $\ldots$ & $\ldots$ \\
\hline Caustic soda (in thousand tons) & 3.7 & 3.0 & 2.8 & 2.8 & 3.0 \\
\hline Fertilizers (in thousand tons) & 11.1 & 3.5 & 12.2 & 19.3 & 40.0 \\
\hline Detergents and soaps (in thousand tons) & 0.6 & 0.3 & 0.5 & 0.4 & 0.3 \\
\hline Knitwear (in million items) & 0.30 & 0.20 & 0.04 & 0.20 & 0.06 \\
\hline Cotton fabrics (in million square meters) & 11.5 & 13.6 & 19.5 & 16.8 & 18.4 \\
\hline Silk fabrics (in million square meters) & 0.3 & 0.2 & 0.1 & 0.0 & 0.0 \\
\hline Rugs, carpets (in million square meters) & 0.3 & 0.5 & 0.3 & 0.4 & 0.4 \\
\hline Hosiery (in million pairs) & 3.1 & 4.4 & 5.2 & 5.5 & 5.7 \\
\hline Shoes (in million pairs) & 0.1 & 0.1 & 0.1 & 0.0 & 0.0 \\
\hline Refrigerators and freezers (in thousands) & 1.7 & 1.7 & 1.4 & 0.6 & 1.9 \\
\hline
\end{tabular}

Source: State Statistical Committee. 
Table A-10. Tajikistan: Electricity Output, Trade and Consumption, 2000-04 (In billions of kilowatt hours)

\begin{tabular}{lrrrrr}
\hline & 2000 & 2001 & 2002 & 2003 & $\begin{array}{c}2004 \\
\text { Prel. }\end{array}$ \\
\hline $\begin{array}{lrrrr}\text { Output } \\
\text { Of which: }\end{array}$ & 14.3 & 14.4 & 15.3 & 16.5 & 16.8 \\
Hydropower & & & & & \\
Thermal power & 14.1 & 14.2 & 15.2 & 16.4 & 16.5 \\
& 0.2 & 0.2 & 0.1 & 0.1 & 0.3 \\
Imports & & & & & \\
& 5.2 & 5.4 & 4.7 & 4.6 & 4.8 \\
Exports & & & & & \\
& 3.9 & 4.1 & 3.9 & 4.6 & 4.4 \\
Total internal consumption (by sector) & & & & & \\
Of which: & 15.6 & 15.7 & 16.1 & 16.5 & $\ldots$ \\
Industry & & & & & \\
Construction & 5.8 & 6.1 & 6.2 & 6.7 & $\ldots$ \\
Agriculture & 0.0 & 0.0 & 0.0 & 0.0 & $\ldots$ \\
Transport & 4.3 & 4.5 & 4.2 & 4.3 & $\ldots$ \\
Other sectors & 0.0 & 0.0 & 0.0 & 0.0 & $\ldots$ \\
Households & 0.5 & 0.4 & 0.4 & 0.4 & $\ldots$ \\
Losses & 2.8 & 2.5 & 2.9 & 2.6 & $\ldots$ \\
Discrepancy & 2.2 & 2.2 & 2.3 & 2.5 & $\ldots$ \\
& -1.0 & -0.1 & 0.1 & 0.0 & $\ldots$ \\
\hline Source: State Stats & & & & & \\
\hline
\end{tabular}

Source: State Statistical Committee. 
Table A-11. Tajikistan: Labor Resources and Employment, 2000-04

\begin{tabular}{|c|c|c|c|c|c|}
\hline & 2000 & 2001 & 2002 & 2003 & 2004 \\
\hline & \multicolumn{5}{|c|}{ (In thousands of persons) } \\
\hline $\begin{array}{l}\text { Population 1/ } \\
\text { Of which: }\end{array}$ & 6,250 & 6,376 & 6,507 & 6,640 & 6,732 \\
\hline \multicolumn{6}{|l|}{ Of which: } \\
\hline Working age 2/ & 3,247 & 3,397 & 3,573 & 3,740 & $\ldots$ \\
\hline Nonworking age & 3,003 & 2,979 & 2,933 & 2,900 & $\ldots$ \\
\hline Urban & 1,660 & 1,691 & 1,720 & 1,758 & $\ldots$ \\
\hline Rural & 4,590 & 4,685 & 4,787 & 4,882 & $\ldots$ \\
\hline Labor force participation rate $1 / 3$ / & 55 & 55 & 53 & 55 & $\ldots$ \\
\hline \multicolumn{6}{|l|}{ Of which: } \\
\hline \multicolumn{6}{|l|}{ Of which: } \\
\hline $\begin{array}{l}\text { Total employment } 4 / \\
\text { Of which: }\end{array}$ & 1,745 & 1,829 & 1,857 & 1,885 & 1,897 \\
\hline Government 6/ & 558 & 520 & 517 & 481 & $\ldots$ \\
\hline Collective farms & 364 & 397 & 425 & 369 & $\ldots$ \\
\hline Cooperatives & 1 & 1 & 0 & 0 & $\ldots$ \\
\hline Private farming & 641 & 684 & 721 & 723 & $\ldots$ \\
\hline Clergy and other religious activity & 1 & 1 & 1 & 1 & $\ldots$ \\
\hline Unallocated & 180 & 227 & 193 & 311 & $\ldots$ \\
\hline Registered unemployment & 49 & 43 & 47 & 47 & 41 \\
\hline Nonworking students $4 /$ & 343 & 357 & 395 & 399 & $\ldots$ \\
\hline Working age population at home 4 / & 1,049 & 1,072 & 1,164 & 1,313 & $\ldots$ \\
\hline & \multicolumn{5}{|c|}{ (In percent of total employment) } \\
\hline $\begin{array}{l}\text { Total labor resources } \\
\text { Of which: }\end{array}$ & 182.6 & 180.5 & 186.0 & 193.0 & .. \\
\hline Economically active population & 102.8 & 102.4 & 102.5 & 102.5 & ... \\
\hline \multicolumn{6}{|l|}{ Of which: } \\
\hline Total employment & 100.0 & 100.0 & 100.0 & 100.0 & .. \\
\hline \multicolumn{6}{|l|}{ Of which: } \\
\hline Government 6/ & 32.0 & 28.4 & 27.8 & 25.5 & $\ldots$ \\
\hline Collective farms & 20.9 & 21.7 & 22.9 & 20.0 & $\ldots$ \\
\hline Cooperatives & 0.0 & 0.0 & 0.0 & 0.0 & $\ldots$ \\
\hline Private farming & 36.7 & 37.4 & 38.8 & 38.4 & $\ldots$ \\
\hline Clergy and other religious activity & 0.1 & 0.1 & 0.1 & 0.1 & $\ldots$ \\
\hline Unallocated & 10.3 & 12.4 & 10.4 & & $\ldots$ \\
\hline Registered unemployment & 2.8 & 2.4 & 2.5 & 2.4 & $\ldots$ \\
\hline Total unemployment & $\ldots$ & $\ldots$ & $\ldots$ & $\ldots$ & $\ldots$ \\
\hline Nonworking students & 19.7 & 19.5 & 20.8 & 21.2 & $\ldots$ \\
\hline Working age population at home & 60.1 & 58.6 & 63.9 & 69.7 & $\ldots$ \\
\hline
\end{tabular}

Source: State Statistical Committee

$1 /$ End of year.

2/ Working age is defined as follows: In 1997-2000, for men 15-59, women 15-54; in 2001, for men 15-60, women 15-55; from 2002 onwards, men is 15-62, women is 15-57.

3/ Defined as the ratio of economically active over working age population.

4/ Annual averages.

5/ Comprises employed and registered unemployed.

6/ Includes central and local governments, state enterprises and state farms. 


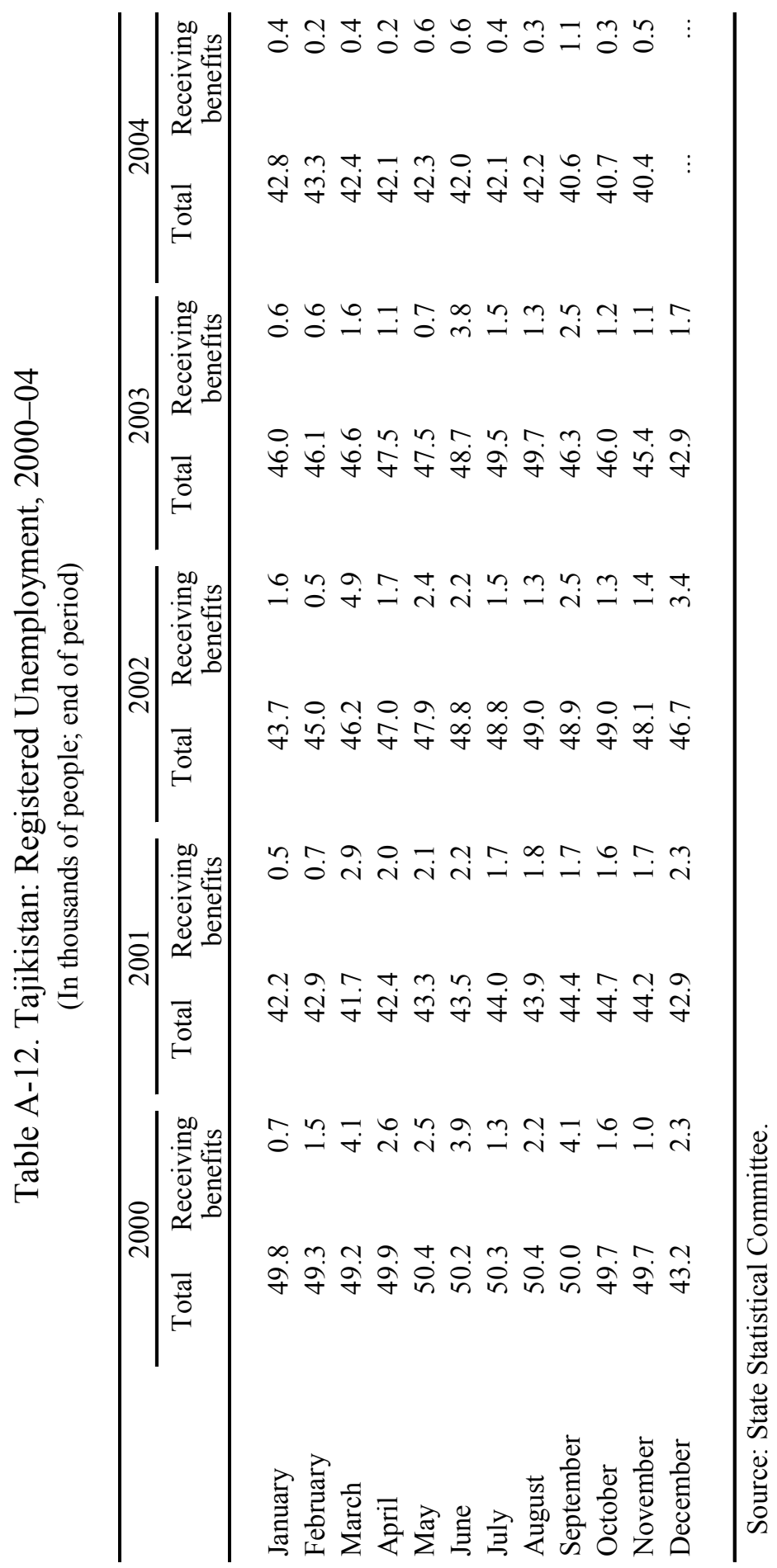


Table A-13. Tajikistan: Employment by Sector of Economy, 2000-04

\begin{tabular}{|c|c|c|c|c|c|}
\hline & 2000 & 2001 & 2002 & 2003 & 2004 \\
\hline & \multicolumn{5}{|c|}{ (In thousands of persons; annual average) } \\
\hline Total employment & 1,745 & 1,829 & 1,857 & 1,885 & 1,897 \\
\hline Material sphere & 1,416 & 1,495 & 1,516 & 1,554 & $\ldots$ \\
\hline \multicolumn{6}{|l|}{ Of which: } \\
\hline Agriculture & 1,135 & 1,218 & 1,255 & 1,275 & $\ldots$ \\
\hline Industry & 121 & 123 & 122 & 115 & $\ldots$ \\
\hline Construction & 36 & 33 & 31 & 31 & $\ldots$ \\
\hline Transport and communication & 42 & 45 & 43 & 45 & $\ldots$ \\
\hline Trade, supply and other & 81 & 76 & 65 & 88 & $\ldots$ \\
\hline Nonmaterial sphere & 326 & 334 & 341 & 331 & $\ldots$ \\
\hline \multicolumn{6}{|l|}{ Of which: } \\
\hline Government & 27 & 28 & 34 & 28 & $\ldots$ \\
\hline Education, culture and art & 179 & 180 & 185 & 183 & $\ldots$ \\
\hline $\begin{array}{l}\text { Medical care, physical training } \\
\text { and social security }\end{array}$ & 82 & 79 & 76 & 78 & $\ldots$ \\
\hline Scientific research & 5 & 5 & 5 & 4 & $\ldots$ \\
\hline Communal services & 27 & 29 & 32 & 31 & $\ldots$ \\
\hline \multirow[t]{2}{*}{ Other } & 3 & 14 & 9 & 7 & $\ldots$ \\
\hline & \multicolumn{5}{|c|}{ (In percent of total employment) } \\
\hline Total employment & 100.0 & 100.0 & 100.0 & 100.0 & $\ldots$ \\
\hline Material sphere & 81.1 & 81.8 & 81.6 & 82.4 & $\ldots$ \\
\hline \multicolumn{6}{|l|}{ Of which: } \\
\hline Agriculture & 65.0 & 66.6 & 67.6 & 67.6 & $\ldots$ \\
\hline Industry & 6.9 & 6.7 & 6.6 & 6.1 & $\ldots$ \\
\hline Construction & 2.1 & 1.8 & 1.7 & 1.6 & $\ldots$ \\
\hline Transport and communication & 2.4 & 2.5 & 2.3 & 2.4 & $\ldots$ \\
\hline Trade, supply and other & 4.7 & 4.1 & 3.5 & 4.7 & $\ldots$ \\
\hline Nonmaterial sphere & 18.7 & 18.2 & 18.4 & 17.6 & $\ldots$ \\
\hline \multicolumn{6}{|l|}{ Of which: } \\
\hline Government & 1.5 & 1.5 & 1.8 & 1.5 & $\ldots$ \\
\hline Education, culture and art & 10.3 & 9.8 & 10.0 & 9.7 & $\ldots$ \\
\hline Medical care, physical training & & & & & \\
\hline and social security & 4.7 & 4.3 & 4.1 & 4.1 & $\ldots$ \\
\hline Scientific research & 0.3 & 0.3 & 0.3 & 0.2 & $\ldots$ \\
\hline Communal services & 1.5 & 1.6 & 1.7 & 1.6 & $\ldots$ \\
\hline Other & 0.2 & 0.8 & 0.5 & 0.4 & $\ldots$ \\
\hline
\end{tabular}

Source: State Statistical Committee. 
Table A-14. Tajikistan: Sectoral Output, Employment and Productivity, 2000-03 $($ Index $1991=100)$

\begin{tabular}{lrrrr}
\hline & 2000 & 2001 & 2002 & 2003 \\
\hline Industry & & & & \\
$\quad$ Output & 42.2 & 48.5 & 52.6 & 57.9 \\
Employment & 47.3 & 48.0 & 47.7 & 44.9 \\
$\quad$ Productivity & 89.2 & 100.9 & 110.3 & 128.9 \\
Agriculture & & & & \\
$\quad$ Output & 48.2 & 52.9 & 61.3 & 67.4 \\
Employment & 128.8 & 138.2 & 142.4 & 144.6 \\
$\quad$ Productivity & 44.4 & 38.3 & 43.0 & 46.6 \\
Transport & & & & $\ldots$ \\
$\quad$ Output & $\ldots$ & $\ldots$ & $\ldots$ & $\ldots$ \\
$\quad$ Employment $1 /$ & 64.4 & 69.1 & 66.0 & 69.1 \\
$\quad$ Productivity & $\ldots$ & $\ldots$ & $\ldots$ & $\ldots$ \\
Construction & & & $\ldots$ & $\ldots$ \\
$\quad$ Output & $\ldots$ & $\ldots$ & $\ldots$ & $\ldots$ \\
Employment & 27.8 & 29.7 & 28.4 & 29.7 \\
$\quad$ Productivity & $\ldots$ & $\ldots$ & $\ldots$ & $\ldots$ \\
\hline
\end{tabular}

Sources: Tajik authorities; and Fund staff estimates.

$1 /$ Includes transport and communications. 
Table A-15. Tajikistan: Consumer Price Index, 2000-04

\begin{tabular}{|c|c|c|c|c|}
\hline & Overall CPI & Foodstuff & Nonfood & Services \\
\hline & \multicolumn{4}{|c|}{ (Monthly percent change) } \\
\hline 2003 January & 3.7 & 1.7 & 0.9 & 25.4 \\
\hline February & 1.5 & 1.8 & 0.8 & 0.5 \\
\hline March & 2.5 & 3.4 & 0.3 & 0.3 \\
\hline April & 1.4 & 1.3 & 0.4 & 3.8 \\
\hline May & -0.4 & -0.7 & 0.6 & 0.4 \\
\hline June & -0.8 & -2.3 & 1.2 & 5.3 \\
\hline July & 0.4 & 0.6 & 1.1 & -9.0 \\
\hline August & 0.3 & -0.6 & 0.4 & 0.1 \\
\hline September & 1.1 & 1.2 & 0.6 & 1.5 \\
\hline October & 3.8 & 3.0 & 0.7 & 14.7 \\
\hline November & 0.6 & 0.2 & 0.9 & 2.6 \\
\hline December & 0.3 & 0.1 & 0.1 & 1.5 \\
\hline 2004 January & 0.7 & 0.1 & 0.1 & 5.8 \\
\hline February & 0.2 & -0.2 & 1.0 & 1.0 \\
\hline March & 0.1 & -0.1 & 0.0 & 0.9 \\
\hline April & 0.2 & 0.4 & 0.3 & -1.1 \\
\hline May & 0.1 & 0.3 & 2.8 & -6.3 \\
\hline June & -0.3 & -0.4 & 0.1 & 0.0 \\
\hline July & 1.1 & 1.7 & 0.3 & -0.6 \\
\hline August & 0.5 & 0.4 & 0.6 & 1.0 \\
\hline September & 1.7 & 2.5 & 0.1 & -0.1 \\
\hline October & 1.1 & 0.4 & 0.2 & 7.4 \\
\hline November & -0.3 & -1.1 & 0.5 & 3.1 \\
\hline \multirow[t]{2}{*}{ December } & 0.4 & 0.5 & 0.1 & 0.3 \\
\hline & \multicolumn{4}{|c|}{ (Quarterly percent change; end-period) } \\
\hline $2000 \mathrm{Q} 1$ & 4.9 & 5.4 & 4.0 & 2.0 \\
\hline Q2 & 11.3 & 13.5 & 3.3 & 3.8 \\
\hline Q3 & 14.1 & 15.3 & 11.1 & 2.9 \\
\hline Q4 & 20.7 & 20.6 & 20.7 & 22.8 \\
\hline $2001 \mathrm{Q} 1$ & 5.0 & 6.1 & 1.7 & 1.0 \\
\hline Q2 & 3.3 & 4.0 & 0.7 & 0.6 \\
\hline Q3 & -1.4 & -2.7 & 3.5 & 0.7 \\
\hline Q4 & 5.2 & 5.5 & 4.3 & 0.7 \\
\hline 2002 Q1 & 2.9 & 3.5 & 1.5 & 2.0 \\
\hline Q2 & 2.8 & 3.1 & 1.2 & 2.2 \\
\hline Q3 & 4.2 & 5.2 & 0.8 & 3.7 \\
\hline Q4 & 3.8 & 4.3 & 2.7 & 1.8 \\
\hline 2003 Q1 & 7.9 & 7.1 & 2.1 & 26.4 \\
\hline Q2 & 0.2 & -1.7 & 2.2 & 9.7 \\
\hline Q3 & 0.4 & 1.2 & 2.1 & -7.5 \\
\hline Q4 & 4.7 & 3.3 & 1.7 & 19.4 \\
\hline 2004 Q1 & 1.0 & -0.1 & 1.0 & 7.9 \\
\hline Q2 & 0.0 & 0.3 & 3.2 & -7.3 \\
\hline Q3 & 3.4 & 4.7 & 1.0 & 0.3 \\
\hline \multirow[t]{2}{*}{ Q4 } & 1.2 & -0.2 & 0.9 & 11.1 \\
\hline & \multicolumn{4}{|c|}{ (Annual percent change; end-period) } \\
\hline 2000 & 60.6 & 66.3 & 44.2 & 34.0 \\
\hline 2001 & 12.5 & 13.7 & 10.5 & 3.2 \\
\hline 2002 & 14.5 & 17.0 & 6.3 & 9.9 \\
\hline 2003 & 13.7 & 10.2 & 8.3 & 53.1 \\
\hline 2004 & 5.6 & 4.6 & 6.4 & 11.4 \\
\hline
\end{tabular}

Source: State Statistical Committee. 
Table A-16. Tajikistan: Wholesale Price Index, 2000-04

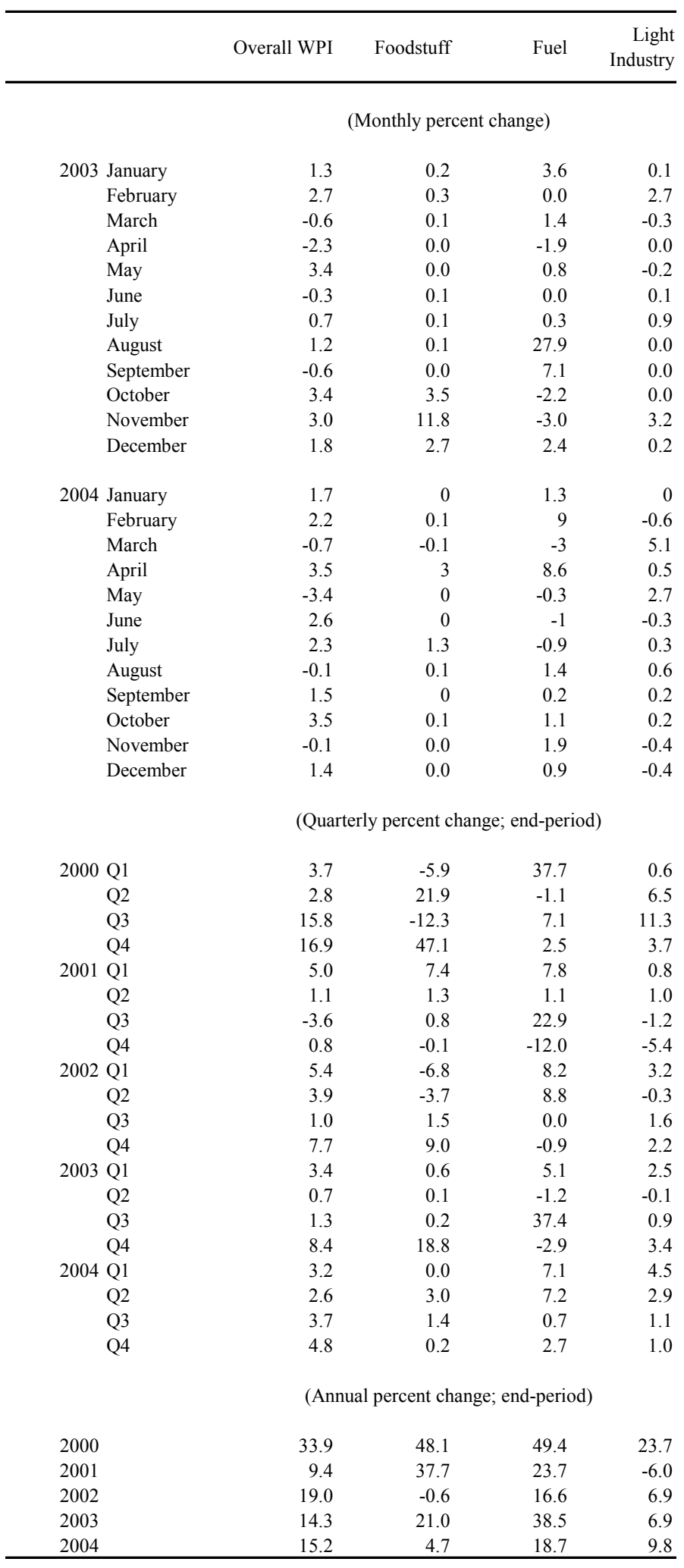

Sources: State Statistical Committee; and Fund staff estimates. 
Table A-17. Tajikistan: Monthly Wages, 2002-04

(In somoni; unless otherwise specified)

\begin{tabular}{|c|c|c|c|c|c|c|c|c|}
\hline & \multicolumn{5}{|c|}{ Average Monthly Wage } & \multirow{2}{*}{$\begin{array}{r}\text { Minimum } \\
\text { Wage }\end{array}$} & \multirow{2}{*}{$\begin{array}{r}\text { Real } \\
\text { Wage } 2 /\end{array}$} & \multirow{2}{*}{$\begin{array}{r}\text { Percent } \\
\text { Change } \\
\text { in CPI }\end{array}$} \\
\hline & Total & Industry & Agriculture & Construction & Services & & & \\
\hline \multicolumn{9}{|l|}{2002} \\
\hline January & 26.52 & 79.50 & 8.50 & 56.47 & 22.02 & 4.00 & 233.5 & 1.6 \\
\hline February & 29.52 & 80.45 & 11.24 & 54.69 & 23.74 & 4.00 & 257.6 & 0.9 \\
\hline March & 31.64 & 92.01 & 11.88 & 61.80 & 28.50 & 4.00 & 275.0 & 0.4 \\
\hline April & 28.70 & 83.00 & 10.82 & 73.60 & 25.60 & 4.00 & 241.9 & 3.1 \\
\hline May & 29.70 & 85.36 & 13.28 & 69.52 & 27.69 & 4.00 & 249.4 & 0.4 \\
\hline June & 31.41 & 84.42 & 15.70 & 80.85 & 29.80 & 4.00 & 265.7 & -0.7 \\
\hline July & 30.73 & 86.49 & 15.35 & 73.48 & 27.92 & 4.00 & 257.9 & 0.8 \\
\hline August & 31.92 & 90.24 & 16.84 & 77.61 & 26.54 & 4.00 & 266.5 & 0.5 \\
\hline September & 39.18 & 94.15 & 29.79 & 83.38 & 28.20 & 4.00 & 317.9 & 2.9 \\
\hline October & 38.62 & 94.36 & 28.96 & 78.56 & 28.46 & 4.00 & 312.1 & 0.4 \\
\hline November & 40.52 & 106.03 & 27.41 & 96.54 & 29.53 & 4.00 & 325.5 & 0.6 \\
\hline December & 45.57 & 111.72 & 28.90 & 115.64 & 33.90 & 4.00 & 356.1 & 2.8 \\
\hline \multicolumn{9}{|l|}{2003} \\
\hline January & 38.34 & 99.69 & 15.04 & 80.56 & 28.54 & 4.00 & 288.9 & 3.7 \\
\hline February & 38.77 & 100.55 & 15.34 & 81.74 & 29.45 & 4.00 & 287.8 & 1.5 \\
\hline March & 40.23 & 111.57 & 15.52 & 101.52 & 32.64 & 4.00 & 291.4 & 2.5 \\
\hline April & 39.96 & 107.51 & 15.82 & 94.89 & 34.38 & 5.00 & 285.4 & 1.4 \\
\hline May & 39.94 & 111.96 & 17.02 & 106.24 & 34.99 & 5.00 & 286.5 & -0.4 \\
\hline June & 42.58 & 114.02 & 19.98 & 108.89 & 39.98 & 5.00 & 307.8 & -0.8 \\
\hline July & 42.67 & 110.92 & 22.04 & 103.76 & 36.47 & 5.00 & 309.7 & -0.4 \\
\hline August & 41.52 & 117.30 & 21.19 & 112.52 & 35.03 & 5.00 & 302.3 & -0.3 \\
\hline September & 52.59 & 123.29 & 38.36 & 128.74 & 38.73 & 5.00 & 378.7 & 1.1 \\
\hline October & 60.26 & 123.25 & 56.77 & 120.68 & 37.56 & 5.00 & 418.1 & 3.8 \\
\hline November & 55.58 & 122.93 & 42.82 & 118.92 & 39.85 & 5.00 & 383.3 & 0.6 \\
\hline December & 63.51 & 135.78 & 44.68 & 152.25 & 47.07 & 5.00 & 436.7 & 0.3 \\
\hline \multicolumn{9}{|l|}{2004} \\
\hline January & 54.05 & 124.61 & 26.89 & 119.22 & 53.96 & 7.00 & 369.1 & 0.7 \\
\hline February & 53.76 & 127.26 & 24.30 & 120.31 & 55.65 & 7.00 & 366.3 & 0.2 \\
\hline March & 60.37 & 149.69 & 24.46 & 150.23 & 71.10 & 7.00 & 411.1 & 0.1 \\
\hline April & 55.00 & 144.99 & 23.57 & 144.79 & 66.77 & 7.00 & 373.8 & 0.2 \\
\hline May & 55.96 & 152.36 & 26.30 & 155.51 & 64.28 & 7.00 & 380.1 & 0.1 \\
\hline June & 61.20 & 154.21 & 29.16 & 163.24 & 69.52 & 7.00 & 416.8 & -0.3 \\
\hline July & 57.25 & 146.11 & 28.71 & 158.21 & 65.70 & 7.00 & 385.6 & 1.1 \\
\hline August & 58.11 & 148.80 & 29.27 & 152.84 & 70.48 & 7.00 & 389.3 & 0.5 \\
\hline September & 73.73 & 156.21 & 56.17 & 179.13 & 78.01 & 7.00 & 485.6 & 1.7 \\
\hline October & 75.18 & 174.52 & 60.04 & 166.22 & 63.22 & 7.00 & 489.8 & 1.1 \\
\hline November & 71.77 & 157.49 & 47.87 & 308.02 & 74.88 & 7.00 & 469.0 & -0.3 \\
\hline December & 81.36 & 161.40 & 56.00 & 207.50 & 70.00 & 7.00 & 529.5 & 0.4 \\
\hline
\end{tabular}

Sources: State Statistical Committee; and Fund staff estimates.

1 / The data in this table are based on preliminary monthly figures on wages and employment, while average annual wages reported in Table 18 are final and reconciled annual data. As a result, annual averages in Table 17 are not entirely consistent with the data reported in Table 18.

2/ Index deflated by the CPI (July 1995=100). 
Table A-18. Tajikistan: Average Monthly Wages by Sector, 2000-04 1/

\begin{tabular}{|c|c|c|c|c|c|}
\hline & 2000 & 2001 & 2002 & 2003 & 2004 \\
\hline & \multicolumn{5}{|c|}{ (In somoni) } \\
\hline Total economy & 15.6 & 23.5 & 32.6 & 44.6 & 60.8 \\
\hline \multicolumn{6}{|l|}{ Of which: } \\
\hline Agriculture & 7.8 & 13.7 & 18.9 & 27.0 & 35.0 \\
\hline Industry & 47.1 & 71.2 & 92.5 & 114.2 & 144.1 \\
\hline Forestry & 5.3 & 7.0 & 10.7 & 13.0 & 20.7 \\
\hline Transportation & 31.0 & 48.9 & 69.6 & 101.1 & 147.6 \\
\hline Communication & 38.4 & 59.6 & 95.2 & 149.0 & 212.8 \\
\hline Construction & 38.9 & 55.4 & 74.8 & 100.0 & 150.8 \\
\hline Trade and supplies & 16.9 & 23.1 & 32.7 & 46.1 & 50.7 \\
\hline Housing and municipal services & 18.3 & 26.3 & 36.8 & 49.8 & 66.9 \\
\hline Health care & 6.7 & 8.9 & 12.7 & 17.1 & 22.8 \\
\hline Education & 11.6 & 17.3 & 25.6 & 34.4 & 43.4 \\
\hline Arts and culture & 11.5 & 18.3 & 24.2 & 33.8 & 40.7 \\
\hline Sciences & 16.4 & 23.4 & 34.8 & 44.8 & 66.5 \\
\hline Banking and insurance & 76.7 & 90.5 & 118.5 & 174.9 & 230.9 \\
\hline General government & 23.9 & 29.9 & 49.2 & 63.3 & 74.2 \\
\hline Private enterprises & $\ldots$ & 35.04 & 62.25 & 88.6 & 136.4 \\
\hline & \multicolumn{5}{|c|}{ (Percent change) } \\
\hline Total economy & 34.1 & 50.9 & 38.5 & 37.1 & 36.3 \\
\hline \multicolumn{6}{|l|}{ Of which: } \\
\hline Agriculture & 44.6 & 76.0 & 38.3 & 42.6 & 29.5 \\
\hline Industry & 31.5 & 51.2 & 29.8 & 23.5 & 26.2 \\
\hline Forestry & -8.7 & 32.1 & 52.9 & 53.9 & 53.9 \\
\hline Transportation & 33.3 & 57.8 & 42.5 & 45.2 & 46.0 \\
\hline Communication & 34.1 & 55.0 & 59.9 & 56.4 & 42.8 \\
\hline Construction & 5.0 & 42.4 & 35.0 & 33.8 & 50.8 \\
\hline Trade and supplies & 42.1 & 36.9 & 41.6 & 41.0 & 10.0 \\
\hline Housing and municipal services & 8.1 & 43.3 & 40.1 & 35.5 & 34.2 \\
\hline Health care & 50.5 & 31.5 & 43.4 & 34.8 & 33.2 \\
\hline Education & 51.7 & 49.2 & 48.4 & 34.5 & 26.1 \\
\hline Arts and culture & 39.5 & 58.4 & 32.4 & 39.8 & 20.3 \\
\hline Sciences & 0.0 & 43.0 & 48.6 & 28.8 & 48.3 \\
\hline Banking and insurance & 56.8 & 18.0 & 30.9 & 47.6 & 32.0 \\
\hline General government & 4.7 & 25.5 & 64.2 & 28.7 & 17.3 \\
\hline Private enterprises & $\ldots$ & $\ldots$ & 77.7 & 42.3 & 54.0 \\
\hline
\end{tabular}

Source: State Statistical Committee.

1/ Data are based on final and reconciled annual data on wages and employment, while average annual wages reported in Table 17 are preliminary monthly figures. As a result, annual averages in Table 18 are not entirely consistent with the data reported in Table 17. 
Table A-19. Tajikistan: General Government Operations, 2000-04

\begin{tabular}{|c|c|c|c|c|c|}
\hline & 2000 & 2001 & 2002 & 2003 & 2004 \\
\hline & \multicolumn{5}{|c|}{ (In millions of somoni) } \\
\hline Total revenue & 245 & 382 & 560 & 824 & 1,104 \\
\hline Tax revenue & 233 & 353 & 501 & 713 & 934 \\
\hline Individual income tax & 22 & 33 & 39 & 51 & 68 \\
\hline Enterprise profits tax & 11 & 14 & 21 & 24 & 36 \\
\hline Payroll tax & 30 & 45 & 65 & 87 & 120 \\
\hline Value-added tax & 46 & 86 & 159 & 248 & 349 \\
\hline Excise taxes & 9 & 16 & 29 & 49 & 57 \\
\hline Customs revenue & 26 & 52 & 60 & 72 & 98 \\
\hline Taxes on aluminum and cotton & 59 & 63 & 63 & 88 & 87 \\
\hline Property tax & 11 & 15 & 19 & 28 & 34 \\
\hline Other internal indirect taxes & 17 & 27 & 43 & 59 & 76 \\
\hline Other taxes & 3 & 3 & 3 & 7 & 8 \\
\hline Non-tax revenue & 12 & 29 & 51 & 97 & 130 \\
\hline Grants & 0 & 0 & 8 & 15 & 41 \\
\hline Expenditure & 346 & 462 & 642 & 908 & 1,273 \\
\hline Current & 225 & 332 & 459 & 597 & 770 \\
\hline Wages and salaries & 67 & 82 & 108 & 133 & 168 \\
\hline Goods and services & 82 & 140 & 182 & 261 & 370 \\
\hline Subsidies & 13 & 12 & 17 & 19 & 23 \\
\hline Social safety net & 40 & 60 & 89 & 126 & 166 \\
\hline Interest payments & 24 & 38 & 63 & 59 & 43 \\
\hline Capital & 119 & 127 & 181 & 310 & 500 \\
\hline Domestically financed & 48 & 74 & 102 & 182 & 311 \\
\hline Externally financed PIP & 72 & 54 & 79 & 128 & 188 \\
\hline Net lending & 1 & 2 & 1 & 1 & 3 \\
\hline Balance on a cash basis (deficit -) & -101 & -80 & -82 & -84 & -169 \\
\hline Financing & 101 & 80 & 82 & 84 & 169 \\
\hline External & 118 & 75 & 86 & 134 & 271 \\
\hline Domestic & -18 & 6 & -5 & -50 & -102 \\
\hline \multirow[t]{2}{*}{ Of which: Privatization proceeds } & 17 & 7 & 31 & 22 & 26 \\
\hline & \multicolumn{5}{|c|}{ (In percent of GDP; unless otherwise specified) } \\
\hline Total revenue & 13.6 & 15.2 & 16.7 & 17.3 & 17.9 \\
\hline Tax revenue & 12.9 & 14.1 & 15.0 & 15.0 & 15.2 \\
\hline Individual income tax & 1.2 & 1.3 & 1.2 & 1.1 & 1.1 \\
\hline Enterprise profits tax & 0.6 & 0.6 & 0.6 & 0.5 & 0.6 \\
\hline Payroll tax & 1.7 & 1.8 & 1.9 & 1.8 & 1.9 \\
\hline Value-added tax & 2.5 & 3.4 & 4.8 & 5.2 & 5.7 \\
\hline Excise taxes & 0.5 & 0.6 & 0.9 & 1.0 & 0.9 \\
\hline Customs revenue & 1.4 & 2.1 & 1.8 & 1.5 & 1.6 \\
\hline Taxes on aluminum and cotton & 3.3 & 2.5 & 1.9 & 1.9 & 1.4 \\
\hline Property tax & 0.6 & 0.6 & 0.6 & 0.6 & 0.6 \\
\hline Other internal indirect taxes & 0.9 & 1.1 & 1.3 & 1.2 & 1.2 \\
\hline Other taxes & 0.1 & 0.1 & 0.1 & 0.1 & 0.1 \\
\hline Non-tax revenue & 0.7 & 1.1 & 1.5 & 2.0 & 2.1 \\
\hline Grants & 0.0 & 0.0 & 0.2 & 0.3 & 0.7 \\
\hline Expenditure & 19.2 & 18.4 & 19.2 & 19.1 & 20.7 \\
\hline Current & 12.5 & 13.2 & 13.7 & 12.6 & 12.5 \\
\hline Wages and salaries & 3.7 & 3.3 & 3.2 & 2.8 & 2.7 \\
\hline Goods and services & 4.5 & 5.6 & 5.5 & 5.5 & 6.0 \\
\hline Subsidies & 0.7 & 0.5 & 0.5 & 0.4 & 0.4 \\
\hline Social safety net & 2.2 & 2.4 & 2.7 & 2.6 & 2.7 \\
\hline Interest payments & 1.3 & 1.5 & 1.9 & 1.2 & 0.7 \\
\hline Capital & 6.6 & 5.1 & 5.4 & 6.5 & 8.1 \\
\hline Domestically financed & 2.6 & 2.9 & 3.1 & 3.8 & 5.1 \\
\hline Externally financed PIP & 4.0 & 2.1 & 2.4 & 2.7 & 3.1 \\
\hline Net lending & 0.1 & 0.1 & 0.0 & 0.0 & 0.1 \\
\hline Balance on a cash basis (deficit -) & -5.6 & -3.2 & -2.4 & -1.8 & -2.7 \\
\hline Financing & 5.6 & 3.2 & 2.4 & 1.8 & 2.7 \\
\hline External & 6.5 & 3.0 & 2.6 & 2.8 & 4.4 \\
\hline Domestic & -1.0 & 0.2 & -0.1 & -1.1 & -1.7 \\
\hline Of which: Privatization proceeds & 1.0 & 0.3 & 0.9 & 0.5 & 0.4 \\
\hline Nominal GDP (in millions of somoni) & 1,807 & 2,512 & 3,345 & 4,758 & 6,158 \\
\hline
\end{tabular}


Table A-20. Tajikistan: State Budget by Functional Classification of Expenditures, 2000-04 (In millions of somoni; unless otherwise specified)

\begin{tabular}{|c|c|c|c|c|c|}
\hline & 2000 & 2001 & 2002 & 2003 & 2004 \\
\hline Total expenditure (excl. PIP) & 346 & 462 & 642 & 908 & 1,273 \\
\hline General service & 49 & 66 & 91 & 132 & 117 \\
\hline Protection & 43 & 57 & 71 & 94 & 134 \\
\hline Defense & 22 & 29 & 36 & 47 & 75 \\
\hline Law enforcement & 21 & 28 & 35 & 46 & 59 \\
\hline Social services & 119 & 172 & 233 & 315 & 437 \\
\hline Education & 36 & 63 & 87 & 112 & 161 \\
\hline Health & 16 & 24 & 30 & 43 & 62 \\
\hline Social protection & 42 & 47 & 67 & 109 & 153 \\
\hline Other social services & 25 & 38 & 49 & 51 & 60 \\
\hline Economic services & 37 & 58 & 64 & 101 & 119 \\
\hline Interest payment & 24 & 38 & 63 & 59 & 43 \\
\hline Others & 2 & 17 & 41 & 80 & 236 \\
\hline \multirow[t]{2}{*}{ Externally financed PIP } & 72 & 54 & 79 & 128 & 188 \\
\hline & \multicolumn{5}{|c|}{ (In percent of GDP) } \\
\hline Total expenditure (excl. PIP) & 19.2 & 18.4 & 19.2 & 19.1 & 20.7 \\
\hline General service & 2.7 & 2.6 & 2.7 & 2.8 & 1.9 \\
\hline Protection & 2.4 & 2.3 & 2.1 & 2.0 & 2.2 \\
\hline Defense & 1.2 & 1.2 & 1.1 & 1.0 & 1.2 \\
\hline Law enforcement & 1.2 & 1.1 & 1.0 & 1.0 & 1.0 \\
\hline Social services & 6.6 & 6.9 & 7.0 & 6.6 & 7.1 \\
\hline Education & 2.0 & 2.5 & 2.6 & 2.4 & 2.6 \\
\hline Health & 0.9 & 1.0 & 0.9 & 0.9 & 1.0 \\
\hline Social protection & 2.3 & 1.9 & 2.0 & 2.3 & 2.5 \\
\hline Other social services & 1.4 & 1.5 & 1.5 & 1.1 & 1.0 \\
\hline Economic services & 2.1 & 2.3 & 1.9 & 2.1 & 1.9 \\
\hline Interest payment & 1.3 & 1.5 & 1.9 & 1.2 & 0.7 \\
\hline Others & 0.1 & 0.7 & 1.2 & 1.7 & 3.8 \\
\hline Externally financed PIP & 4.0 & 2.1 & 2.4 & 2.7 & 3.1 \\
\hline \multicolumn{6}{|l|}{ Memorandum item: } \\
\hline Nominal GDP (in millions of somoni) & 1,807 & 2,512 & 3,345 & 4,758 & 6,158 \\
\hline
\end{tabular}

Source: Ministry of Finance. 
Table A-21. Tajikistan: Operations of the Consolidated General Government, 2000-04

\begin{tabular}{|c|c|c|c|c|c|}
\hline & 2000 & 2001 & 2002 & 2003 & 2004 \\
\hline & \multicolumn{5}{|c|}{ (In millions of somoni) } \\
\hline Revenue & 245 & 382 & 560 & 824 & 1,104 \\
\hline Republic and local budget & 216 & 337 & 495 & 738 & 985 \\
\hline Tax revenue & 204 & 308 & 444 & 641 & 855 \\
\hline Nontax revenue & 12 & 29 & 51 & 97 & 130 \\
\hline Social Protection Fund & 30 & 45 & 65 & 87 & 120 \\
\hline Expenditure & 346 & 462 & 642 & 908 & 1,273 \\
\hline Republic and local budget $1 /$ & 314 & 417 & 570 & 807 & 1,107 \\
\hline Social Protection Fund & 32 & 45 & 72 & 101 & 166 \\
\hline Overall balance (deficit -) & -101 & -80 & -82 & -84 & -169 \\
\hline Financing & 101 & 80 & 82 & 84 & 169 \\
\hline External & 118 & 75 & 86 & 134 & 271 \\
\hline Domestic & -18 & 6 & -5 & -50 & -102 \\
\hline \multirow[t]{2}{*}{ Of which: Privatization proceeds } & 17 & 7 & 31 & 22 & 26 \\
\hline & \multicolumn{5}{|c|}{ (In percent of GDP) } \\
\hline Revenue & 13.6 & 15.2 & 16.7 & 17.3 & 17.9 \\
\hline State budget & 11.9 & 13.4 & 14.8 & 15.5 & 16.0 \\
\hline Social security funds & 1.7 & 1.8 & 1.9 & 1.8 & 1.9 \\
\hline Expenditure & 19.2 & 18.4 & 19.2 & 19.1 & 20.7 \\
\hline State budget & 17.4 & 16.6 & 17.0 & 17.0 & 18.0 \\
\hline Social security funds & 1.8 & 1.8 & 2.1 & 2.1 & 2.7 \\
\hline Overall balance (deficit -) & -5.6 & -3.2 & -2.4 & -1.8 & -2.7 \\
\hline Financing: & 5.6 & 3.2 & 2.4 & 1.8 & 2.7 \\
\hline External & 6.5 & 3.0 & 2.6 & 2.8 & 4.4 \\
\hline Domestic & -1.0 & 0.2 & -0.1 & -1.1 & -1.7 \\
\hline Of which: Privatization proceeds & 1.0 & 0.3 & 0.9 & 0.5 & 0.4 \\
\hline Memorandum item: & & & & & \\
\hline Nominal GDP & 1,807 & 2,512 & 3,345 & 4,758 & 6,158 \\
\hline
\end{tabular}

Source: Ministry of Finance. 
Table A-22. Tajikistan: Accounts of the National Bank of Tajikistan, 2000-2004 (End-of-period stock; unless otherwise specified) 1/

\begin{tabular}{|c|c|c|c|c|c|}
\hline & 2000 & 2001 & 2002 & 2003 & 2004 \\
\hline & \multicolumn{5}{|c|}{ (In millions of U.S. dollars; unless otherwise specified) } \\
\hline Net international reserves & -23.8 & -14.5 & 2.7 & 36.0 & 67.4 \\
\hline Gross assets & 87.2 & 95.7 & 96.2 & 135.4 & 189.3 \\
\hline \multirow[t]{2}{*}{ Gross liabilities } & 111.0 & 110.2 & 93.5 & 99.5 & 121.9 \\
\hline & \multicolumn{5}{|c|}{ (In millions of somoni) } \\
\hline Net foreign assets & -52.4 & -37.0 & 8.2 & 106.3 & 204.7 \\
\hline Gross assets & 191.9 & 244.0 & 288.5 & 400.4 & 574.8 \\
\hline Gross liabilities & 244.3 & 281.0 & 280.4 & 294.1 & 370.1 \\
\hline Net domestic assets & 171.5 & 190.5 & 176.9 & 146.3 & 73.1 \\
\hline Net credit to general government & 46.8 & -31.1 & -9.3 & -77.0 & -192.3 \\
\hline Credit to the private sector & 149.6 & 253.3 & 205.2 & 210.9 & 221.2 \\
\hline Claims on banks & 148.7 & 37.6 & 34.1 & 39.0 & 65.6 \\
\hline Claims on private sector & 2.0 & 12.4 & 85.1 & 171.9 & 155.6 \\
\hline Other items, net & -24.8 & -31.7 & -19.0 & 12.4 & 44.1 \\
\hline NBT bills & 0.0 & -0.2 & -9.0 & -8.5 & -5.4 \\
\hline Reserve money & 119.1 & 153.5 & 185.0 & 252.6 & 277.7 \\
\hline Currency in circulation & 96.2 & 110.8 & 140.8 & 172.4 & 204.8 \\
\hline Bank reserves & 18.6 & 32.5 & 35.8 & 63.3 & 70.3 \\
\hline \multicolumn{6}{|l|}{ Of which: } \\
\hline Required reserves & 9.9 & 8.8 & 11.9 & 23.9 & 44.7 \\
\hline Somoni & 7.6 & 7.0 & 5.5 & 9.5 & 16.5 \\
\hline Foreign exchange & 2.2 & 1.8 & 6.3 & 14.4 & 28.3 \\
\hline Other & 8.7 & 23.7 & 23.9 & 39.4 & 25.5 \\
\hline Somoni & 4.5 & 15.7 & 17.5 & 32.2 & 22.9 \\
\hline Foreign exchange & 4.3 & 8.0 & 6.4 & 7.2 & 2.6 \\
\hline Other deposits & 4.3 & 10.2 & 8.4 & 16.8 & 2.7 \\
\hline Somoni & 2.1 & 1.5 & 1.3 & 2.8 & 2.2 \\
\hline Foreign exchange & 2.3 & 8.7 & 7.1 & 14.0 & 0.5 \\
\hline Memorandum items: & \multicolumn{5}{|c|}{ (12-month change as a percent of initial reserve money stock) } \\
\hline Net international reserves & 11.4 & 12.9 & 29.4 & 53.0 & 38.9 \\
\hline Net domestic assets & 39.9 & 15.9 & -8.9 & -16.5 & -29.0 \\
\hline Reserve money & 51.4 & 28.9 & 20.5 & 36.5 & 10.0 \\
\hline Official exchange rate (Sm/US\$) & 2.20 & 2.55 & 3.00 & 2.96 & 3.04 \\
\hline
\end{tabular}

Sources: National Bank of Tajikistan; and Fund staff estimates.

1/ Data are based on official SDR/U.S. dollar and somoni/U.S. dollar exchange rates. 
Table A-23. Tajikistan: Monetary Survey, 2000-04 1/

(In millions of somoni; end-of-period stock unless otherwise specified)

\begin{tabular}{|c|c|c|c|c|c|}
\hline & 2000 & 2001 & 2002 & 2003 & 2004 \\
\hline Net foreign assets & -192.3 & -251.0 & -267.2 & -179.5 & -272.2 \\
\hline National Bank of Tajikistan & -52.4 & -37.0 & 8.2 & 106.3 & 204.7 \\
\hline Commercial banks & -139.9 & -214.0 & -275.4 & -285.8 & -476.9 \\
\hline Net domestic assets & 354.2 & 486.5 & 585.4 & 580.2 & 892.6 \\
\hline $\begin{array}{l}\text { Net credit to general government } \\
\text { Of which: }\end{array}$ & 37.1 & -36.9 & -16.5 & -93.7 & -217.9 \\
\hline Somoni credits & 132.6 & 90.4 & 154.2 & 153.8 & 155.4 \\
\hline Treasury bills & 0.7 & 5.5 & 3.3 & 0.3 & 0.3 \\
\hline Deposits (-) & -36.9 & -46.9 & -73.0 & -139.5 & -207.6 \\
\hline Counterpart deposits & -59.1 & -85.8 & -101.0 & -108.6 & -166.0 \\
\hline Credit to the private sector & 346.2 & 575.2 & 627.2 & 695.5 & 1098.2 \\
\hline Of which: Credit excluding NBT & 100.3 & 321.9 & 456.1 & 523.7 & 942.6 \\
\hline Cotton financing & $\ldots$ & $\ldots$ & 365.0 & 375.5 & 626.2 \\
\hline Other items net & -29.1 & -51.8 & -25.3 & -21.6 & 12.3 \\
\hline Broad money & 153.8 & 215.3 & 300.7 & 388.7 & 444.4 \\
\hline Somoni broad money & 106.8 & 140.5 & 194.4 & 251.0 & 264.9 \\
\hline Currency outside banks & 86.8 & 103.6 & 135.6 & 158.1 & 175.4 \\
\hline Deposits & 20.0 & 36.8 & 58.8 & 92.9 & 89.5 \\
\hline Foreign currency deposits & 47.0 & 74.8 & 106.3 & 137.7 & 179.5 \\
\hline Bills payable $5 /$ & 8.1. & 20.2 & 17.5 & 12.0 & 175.9 \\
\hline \multicolumn{6}{|l|}{ Memorandum items: } \\
\hline Broad money (12-month percent change) & 78.2 & 40.0 & 39.7 & 29.2 & 14.3 \\
\hline Credit to the private sector (12-month percent change) & 90.2 & 54.3 & 20.2 & 10.9 & 57.9 \\
\hline Quarterly velocity (four-quarter average) & 3.7 & 3.4 & 3.1 & 3.0 & 3.8 \\
\hline Money multiplier & 1.3 & 1.4 & 1.6 & 1.5 & 1.6 \\
\hline
\end{tabular}

Sources: National Bank of Tajikistan; and Fund staff estimates.

1/ Data are based on official SDR/U.S. dollar and somoni/U.S. dollar exchange rates. 


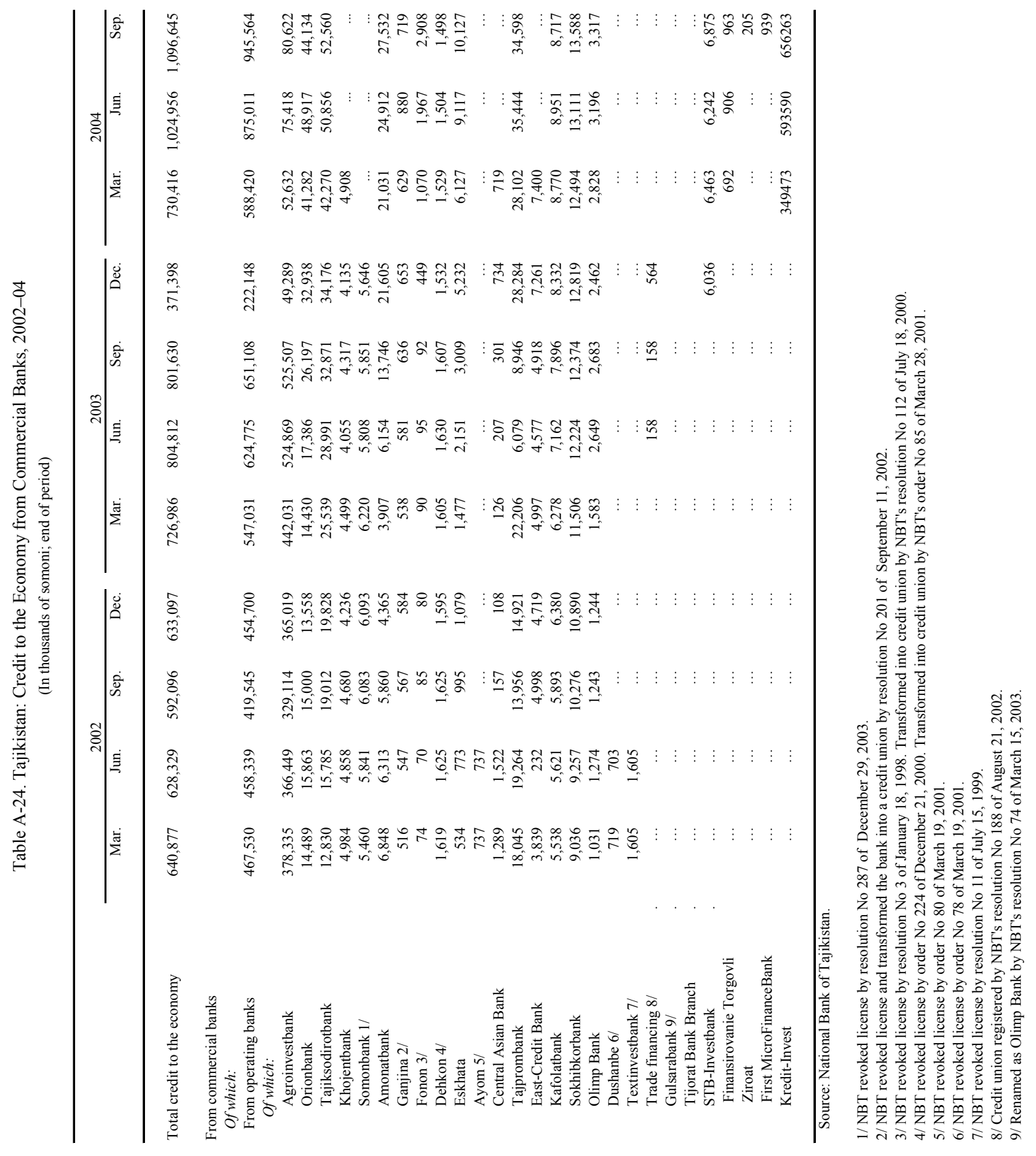




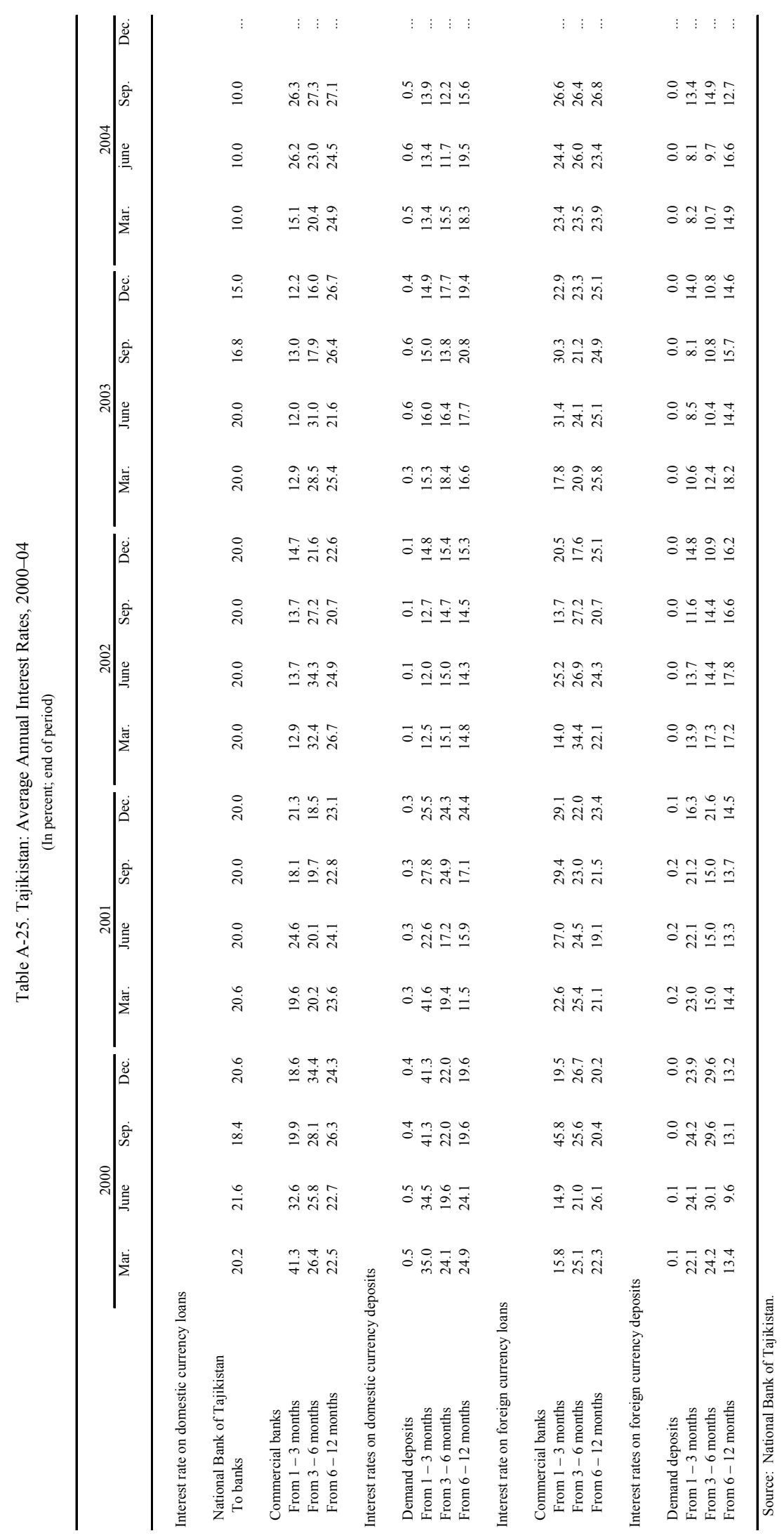


Table A-26. Tajikistan: Balance of Payments, 2000-04 (In millions of U.S. dollars)

\begin{tabular}{|c|c|c|c|c|c|}
\hline & 2000 & 2001 & 2002 & 2003 & $\begin{array}{c}2004 \\
\text { Prel. }\end{array}$ \\
\hline Current account & -62 & -73 & -33 & -20 & -81 \\
\hline Balance on goods and services & -19 & -133 & -161 & -259 & -399 \\
\hline Balance on goods & -24 & -125 & -125 & -205 & -332 \\
\hline Exports & 788 & 652 & 699 & 799 & 915 \\
\hline Of which: aluminum & 424 & 398 & 399 & 430 & 573 \\
\hline cotton fiber & 92 & 71 & 128 & 193 & 162 \\
\hline Imports & 811 & 777 & 824 & 1,003 & 1,247 \\
\hline Balance on services & 4 & -8 & -36 & -54 & -67 \\
\hline Balance on income & -36 & -72 & -57 & -90 & -80 \\
\hline Balance on transfers & 37 & 131 & 184 & 329 & 399 \\
\hline Of which: Migrants' remittances, net 1/ & $\ldots$ & 48 & 65 & 189 & 313 \\
\hline Capital and financial account & 63 & 64 & 54 & 55 & 84 \\
\hline Capital transfers & 5 & 12 & 5 & 14 & 9 \\
\hline Public sector (net) & 17 & -5 & 9 & 32 & -211 \\
\hline Disbursements & 36 & 22 & 28 & 55 & 67 \\
\hline Amortization 2/ & -18 & -27 & -18 & -23 & -278 \\
\hline World Bank & 13 & 25 & 0 & 0 & 25 \\
\hline AsDB & 9 & 0 & 5 & 0 & 0 \\
\hline FDI $2 /$ & 24 & 9 & 36 & 32 & 272 \\
\hline Commercial banks NFA (- increase) & 24 & 20 & 8 & 3 & 63 \\
\hline Electricity credit & 23 & 20 & 4 & 0 & 6 \\
\hline Other capital and errors and omissions & -51 & -18 & -12 & -26 & -80 \\
\hline Overall balance & 1 & -9 & 21 & 35 & 3 \\
\hline Use of international reserves (- increase) & -29 & -8 & -1 & -39 & -54 \\
\hline Financing items & 28 & 18 & -21 & 4 & 51 \\
\hline IMF (net) & 16 & 3 & -24 & -3 & 17 \\
\hline Purchases/disbursements & 26 & 15 & 11 & 11 & 29 \\
\hline Repurchases/repayments & 10 & 12 & 35 & 14 & 12 \\
\hline Other reserve liabilities & 2 & 0 & 0 & 0 & 7 \\
\hline Arrears (+ increase) & 11 & -41 & -23 & 0 & 0 \\
\hline Drawdown on Tajikistan's claim on the CBR & 0 & 0 & 27 & 7 & 14 \\
\hline Exceptional financing 3/ & 0 & 55 & 0 & 0 & 13 \\
\hline \multicolumn{6}{|l|}{ Memorandum items: } \\
\hline GDP (in millions of U.S. dollars) & 955 & 1,033 & 1,193 & 1,556 & 2,073 \\
\hline Current account balance (in percent of GDP) & -6.5 & -7.1 & -2.8 & -1.3 & -3.9 \\
\hline Excluding remittances (in percent of GDP) & -10.3 & -19.8 & -18.3 & -22.4 & -23.1 \\
\hline Terms of trade & -1.6 & -2.0 & -7.5 & 5.1 & -1.4 \\
\hline Net international reserves & -24 & -15 & 3 & 36 & 67 \\
\hline Gross reserves & 87 & 96 & 96 & 135 & 189 \\
\hline (in months of imports) & 2.2 & 1.9 & 1.8 & 1.9 & 2.0 \\
\hline Debt service on public debt & 43.2 & 53.7 & 67.0 & 58.7 & 70.7 \\
\hline (in percent of exports) 4/ & 9.6 & 11.5 & 13.6 & 9.6 & 10.4 \\
\hline Total public sector external debt & 1,226 & 1,017 & 1,010 & 1,031 & 822 \\
\hline (in percent of GDP) & 128.4 & 98.4 & 84.6 & 66.3 & 39.7 \\
\hline
\end{tabular}

Sources: Tajik authorities; and Fund staff estimates.

1/ Includes small export receipts and import payments, which are misclassified.

2/ In 2004 includes debt-for-equity swap with Russia.

3/ Debt cancellation by Pakistan.

4/ Excluding trade in alumina and electricity, which are on barter basis. 
Table A-27. Tajikistan: Exports by Product, 2000-04

\begin{tabular}{|c|c|c|c|c|c|}
\hline & 2000 & 2001 & 2002 & 2003 & $\begin{array}{c}2004 \\
\text { Prel. }\end{array}$ \\
\hline & \multicolumn{5}{|c|}{ (In millions of U.S. dollars) } \\
\hline Total exports, f.o.b & 787.6 & 651.6 & 699.1 & 798.6 & 915.0 \\
\hline Aluminum & 423.9 & 398.4 & 398.6 & 429.6 & 573.0 \\
\hline Cotton fiber & 91.8 & 71.0 & 128.0 & 192.7 & 162.0 \\
\hline Electricity & 180.6 & 78.5 & 67.6 & 55.1 & 60.5 \\
\hline \multirow[t]{2}{*}{ Other } & 91.3 & 103.7 & 104.9 & 121.2 & 119.5 \\
\hline & \multicolumn{5}{|c|}{ (Percent change) } \\
\hline Total exports, f.o.b & 14.3 & -17.3 & 7.3 & 14.2 & 14.6 \\
\hline Aluminum & 37.2 & -6.0 & 0.1 & 7.8 & 33.4 \\
\hline Cotton fiber & 12.0 & -22.7 & 80.3 & 50.5 & -15.9 \\
\hline Electricity & 3.4 & -56.5 & -13.9 & -18.5 & 9.8 \\
\hline \multirow[t]{2}{*}{ Other } & -25.8 & 13.6 & 1.2 & 15.5 & -1.4 \\
\hline & \multicolumn{5}{|c|}{ (Volumes, in units indicated) } \\
\hline Aluminum (thousand tons) & 274 & 286 & 305 & 317 & 352 \\
\hline Cotton fiber (thousand tons) & 79 & 75 & 141 & 149 & 134 \\
\hline Electricity (million kWh) & 3,908 & 4,047 & 3,831 & 4,597 & 4,743 \\
\hline Aluminum $(\$ / T)$ & 1,547 & 1,393 & 1,307 & 1,356 & 1,626 \\
\hline Cotton fiber $(\$ / T)$ & 1,165 & 942 & 909 & 1,291 & 1,206 \\
\hline \multirow[t]{2}{*}{ Electricity $(\$ / k W h)$} & 0.046 & 0.019 & 0.018 & 0.012 & 0.013 \\
\hline & \multicolumn{5}{|c|}{ (Percent change) } \\
\hline Aluminum & 22.0 & 4.0 & 7.0 & 3.9 & 11.2 \\
\hline Cotton fiber & -14.0 & -8.0 & 101.0 & 9.0 & 9.0 \\
\hline Electricity & 2.0 & 3.6 & -4.0 & 19.0 & 19.0 \\
\hline
\end{tabular}

Source: State Statistical Committee. 
Table A-28. Tajikistan: Imports by Product, 2000-04

\begin{tabular}{|c|c|c|c|c|c|}
\hline & 2000 & 2001 & 2002 & 2003 & $\begin{array}{c}2004 \\
\text { Prel. }\end{array}$ \\
\hline & \multicolumn{5}{|c|}{ (In millions of U.S. dollars) } \\
\hline Total imports, f.o.b & 811.2 & 777.0 & 824.3 & $1,003.2$ & $1,247.0$ \\
\hline Alumina & 199.0 & 184.0 & 188.3 & 235.8 & 334.2 \\
\hline Natural gas & 36.4 & 27.0 & 22.4 & 24.3 & 33.2 \\
\hline Petroleum products & 62.7 & 73.2 & 70.2 & 79.6 & 101.9 \\
\hline Electricity & 203.4 & 98.3 & 82.0 & 62.0 & 66.3 \\
\hline Grain and flour & 44.7 & 62.2 & 35.7 & 61.0 & 53.0 \\
\hline \multirow[t]{2}{*}{ Other } & 265.0 & 332.3 & 425.7 & 540.5 & 658.4 \\
\hline & \multicolumn{5}{|c|}{ (Percent change) } \\
\hline Total imports, f.o.b. & 22.4 & -4.2 & 6.1 & 21.7 & 24.3 \\
\hline Alumina & 54.3 & -7.5 & 2.3 & 25.2 & 41.7 \\
\hline Natural gas & 1.1 & -25.8 & -17.0 & 8.5 & 36.6 \\
\hline Petroleum products & 16.1 & 16.7 & -4.1 & 13.4 & 28.0 \\
\hline Electricity & 13.6 & -51.7 & -16.6 & -24.4 & 6.9 \\
\hline Grain and flour & -2.8 & 39.1 & -42.6 & 70.9 & -13.1 \\
\hline \multirow[t]{2}{*}{ Other } & 21.0 & 25.4 & 28.1 & 27.0 & 21.8 \\
\hline & \multicolumn{5}{|c|}{ (In units indicated) } \\
\hline Alumina (thousand tons) & 546.0 & 537.1 & 601.0 & 615.9 & 685.1 \\
\hline Natural gas (thousand cubic meters) & 728.9 & 571.8 & 485.8 & 531.6 & 707.0 \\
\hline Petroleum products (thousand tons) & 202.2 & 276.0 & 278.3 & 305.1 & 363.4 \\
\hline Electricity (million kWh) & $4,342.4$ & $5,396.4$ & $4,659.4$ & $4,617.6$ & $4,676.3$ \\
\hline \multirow[t]{2}{*}{ Grains and Wheat flour (thousand tons) } & 376.7 & 499.0 & 415.6 & 412.7 & 286.0 \\
\hline & \multicolumn{5}{|c|}{ (Percent change) } \\
\hline Alumina & 22.1 & -1.6 & 11.9 & 2.5 & 11.2 \\
\hline Natural gas & -2.8 & -21.6 & -15.0 & 9.4 & 33.0 \\
\hline Petroleum products & -36.4 & 36.5 & 0.8 & 9.6 & 19.1 \\
\hline Electricity & 19.3 & 24.3 & -13.7 & -0.9 & 1.3 \\
\hline Grains and Wheat flour (thousand tons) & 15.5 & 32.5 & -16.7 & -0.7 & -30.7 \\
\hline
\end{tabular}

Source: State Statistical Committee. 
Table A-29. Tajikistan: Trade Indices, 2000-04 1/

\begin{tabular}{|c|c|c|c|c|c|}
\hline & 2000 & 2001 & 2002 & 2003 & $\begin{array}{c}2004 \\
\text { Prel. }\end{array}$ \\
\hline I. Exports & \multicolumn{5}{|c|}{$($ Index; 1995=100) } \\
\hline Value & 101.2 & 83.7 & 89.8 & 102.6 & 117.5 \\
\hline Volume & 121.7 & 126.2 & 144.7 & 154.8 & 163.8 \\
\hline \multirow[t]{2}{*}{ Unit value } & 83.1 & 66.3 & 62.0 & 66.3 & 71.7 \\
\hline & \multicolumn{5}{|c|}{ (Percent change) } \\
\hline Value & 18.4 & -17.3 & 7.3 & 14.3 & 14.5 \\
\hline Volume & 10.4 & 3.7 & 14.7 & 7.0 & 5.8 \\
\hline Unit value & 7.1 & -20.2 & -6.5 & 6.9 & 8.1 \\
\hline II. Imports & \multicolumn{5}{|c|}{$($ Index; 1995=100) } \\
\hline Value & 99.5 & 92.2 & 98.2 & 119.7 & 150.1 \\
\hline Volume & 98.9 & 110.1 & 108.8 & 122.4 & 132.2 \\
\hline \multirow[t]{2}{*}{ Unit value } & 100.6 & 83.8 & 90.3 & 97.8 & 113.5 \\
\hline & \multicolumn{5}{|c|}{ (Percent change) } \\
\hline Value & 20.5 & -7.3 & 6.5 & 21.9 & 25.4 \\
\hline Volume & 9.9 & 11.3 & -1.2 & 12.5 & 8.0 \\
\hline Unit value & 9.5 & -16.7 & 7.8 & 8.3 & 16.1 \\
\hline III. Terms of Trade & \multicolumn{5}{|c|}{$($ Index; 1995=100) } \\
\hline Terms of trade & 77.2 & 70.2 & 61.2 & 64.3 & 63.4 \\
\hline (Percent change) & -4.2 & -9.1 & -12.8 & 5.1 & -1.4 \\
\hline
\end{tabular}

Source: State Statistical Committee. 
Table A-30. Tajikistan: Destination of Exports, 2000-04

\begin{tabular}{|c|c|c|c|c|c|}
\hline & 2000 & 2001 & 2002 & 2003 & $\begin{array}{c}2004 \\
\text { Prel. }\end{array}$ \\
\hline & \multicolumn{5}{|c|}{ (In millions of U.S. dollars) } \\
\hline Total, f.o.b. & 787.6 & 651.6 & 699.1 & 798.6 & 915.0 \\
\hline CIS & 354.4 & 254.8 & 196.8 & 138.8 & 127.6 \\
\hline Russia & 236.3 & 94.5 & 73.3 & 52.2 & 61.0 \\
\hline Uzbekistan & 102.4 & 136.8 & 102.1 & 67.4 & 66.0 \\
\hline Other & 15.8 & 23.5 & 21.3 & 19.2 & 0.6 \\
\hline Non-CIS & 433.2 & 396.8 & 502.3 & 659.8 & 787.4 \\
\hline Europe & 338.7 & 306.3 & 350.5 & 394.7 & 463.3 \\
\hline Asia & 94.5 & 84.7 & 130.0 & 263.5 & 324.0 \\
\hline \multirow[t]{2}{*}{ Other } & 0.0 & 5.9 & 21.8 & 1.6 & 0.1 \\
\hline & \multicolumn{5}{|c|}{ (Percent change) } \\
\hline Total, f.o.b. & 18.3 & -17.3 & 7.3 & 14.2 & 14.6 \\
\hline CIS & 15.8 & -28.1 & -22.8 & -29.5 & -8.1 \\
\hline Russia & 108.8 & -60.0 & -22.4 & -28.8 & 16.9 \\
\hline Uzbekistan & -40.8 & 33.6 & -25.4 & -34.0 & -2.1 \\
\hline Other & -21.1 & 48.9 & -9.1 & -10.0 & -96.9 \\
\hline Non-CIS & 20.5 & -8.4 & 26.6 & 31.4 & 19.3 \\
\hline Europe & 3.8 & -9.6 & 14.4 & 12.6 & 17.4 \\
\hline Asia & 184.0 & -10.4 & 53.5 & 102.7 & 23.0 \\
\hline \multirow[t]{2}{*}{ Other } & $\ldots$ & $\ldots$ & $\ldots$ & $\ldots$ & $\ldots$ \\
\hline & \multicolumn{5}{|c|}{ (In percent of total exports f.o.b.) } \\
\hline Total, f.o.b. & 100.0 & 100.1 & 100.0 & 100.0 & 100.0 \\
\hline CIS & 45.0 & 39.1 & 28.1 & 17.4 & 13.9 \\
\hline Russia & 30.0 & 14.5 & 10.5 & 6.5 & 6.7 \\
\hline Uzbekistan & 13.0 & 21.0 & 14.6 & 8.4 & 7.2 \\
\hline Other & 2.0 & 3.6 & 3.1 & 2.7 & 0.1 \\
\hline Non-CIS & 55.0 & 61.0 & 71.9 & 82.6 & 86.1 \\
\hline Europe & 43.0 & 47.0 & 50.1 & 49.4 & 50.6 \\
\hline Asia & 12.0 & 13.0 & 18.6 & 33.0 & 35.4 \\
\hline Other & 0.0 & 1.0 & 3.1 & 0.2 & 0.0 \\
\hline
\end{tabular}

Sources: Tajik authorities; and Fund staff estimates. 
Table A-31. Tajikistan: Origin of Imports, 2000-04

\begin{tabular}{|c|c|c|c|c|c|}
\hline & 2000 & 2001 & 2002 & 2003 & $\begin{array}{r}2004 \\
\text { Prel. }\end{array}$ \\
\hline & \multicolumn{5}{|c|}{ (In millions of U.S. dollars) } \\
\hline Total, f.o.b. & 811.2 & 777.0 & 824.3 & $1,003.2$ & $1,247.0$ \\
\hline CIS & 614.6 & 538.0 & 548.0 & 727.6 & 914.8 \\
\hline Russia & 105.0 & 129.0 & 164.0 & 138.8 & 333.0 \\
\hline Uzbekistan & 186.0 & 151.0 & 132.0 & 108.4 & 169.0 \\
\hline Other & 323.6 & 258.0 & 252.0 & 480.4 & 412.8 \\
\hline Non-CIS & 196.6 & 239.0 & 276.3 & 275.6 & 332.2 \\
\hline Europe & 83.0 & 67.0 & 81.0 & 102.0 & 163.5 \\
\hline Asia & 30.0 & 71.0 & 78.0 & 96.0 & 124.5 \\
\hline \multirow[t]{2}{*}{ Other } & 83.6 & 101.0 & 117.3 & 77.6 & 44.2 \\
\hline & \multicolumn{5}{|c|}{ (Percent change) } \\
\hline Total, c.i.f. & 13.5 & -4.2 & 6.1 & 21.7 & 24.3 \\
\hline CIS & 14.8 & -12.5 & 1.9 & 32.8 & 25.7 \\
\hline Russia & 5.0 & 22.9 & 27.1 & -15.4 & 139.9 \\
\hline Uzbekistan & -29.5 & -18.8 & -12.6 & -17.9 & 55.9 \\
\hline Other & 88.7 & -20.3 & -2.3 & 90.6 & -14.1 \\
\hline Non-CIS & 9.9 & 21.6 & 15.6 & -0.3 & 20.5 \\
\hline Europe & -35.5 & -19.3 & 20.9 & 25.9 & 60.3 \\
\hline Asia & 36.4 & 136.7 & 9.9 & 23.1 & 29.7 \\
\hline \multirow[t]{2}{*}{ Other } & 194.8 & 20.8 & 16.1 & -33.8 & -43.0 \\
\hline & \multicolumn{5}{|c|}{ (In percent of total imports c.i.f.) } \\
\hline Total, c.i.f. & 100.0 & 100.0 & 100.0 & 100.0 & 100.0 \\
\hline CIS & 83.0 & 81.0 & 66.5 & 72.5 & 73.4 \\
\hline Russia & 16.0 & 17.0 & 19.9 & 13.8 & 26.7 \\
\hline Uzbekistan & 27.0 & 30.0 & 16.0 & 10.8 & 13.6 \\
\hline Other & 40.0 & 34.0 & 30.6 & 47.9 & 33.1 \\
\hline Non-CIS & 17.0 & 19.0 & 33.5 & 27.5 & 26.6 \\
\hline Europe & 12.0 & 11.0 & 9.8 & 10.2 & 13.1 \\
\hline Asia & 4.0 & 7.0 & 9.5 & 9.6 & 10.0 \\
\hline Other & 1.0 & 1.0 & 14.2 & 9.4 & 5.4 \\
\hline
\end{tabular}

Sources: Tajik authorities; and Fund staff estimates. 
Table A-32. Tajikistan: Public External Debt by Creditor, 2000-04

\begin{tabular}{|c|c|c|c|c|c|}
\hline & 2000 & 2001 & 2002 & 2003 & 2004 \\
\hline & & & & & Est. \\
\hline & \multicolumn{5}{|c|}{ (In millions of U.S. dollars) } \\
\hline Total public debt & 1,226 & 1,017 & 1,010 & 1,031 & 822 \\
\hline Bilateral & 532.0 & 530.4 & 484.7 & 467.7 & 213.0 \\
\hline Uzbekistan & 130.0 & 117.2 & 104.4 & 94.0 & 94.0 \\
\hline Russia & 312.5 & 323.3 & 299.7 & 299.7 & 50.0 \\
\hline United States & 22.2 & 21.2 & 20.2 & 19.3 & 18.3 \\
\hline Turkey & 25.7 & 23.1 & 20.5 & 18.0 & 15.4 \\
\hline Kazakhstan & 18.8 & 18.8 & 12.1 & 12.1 & 12.1 \\
\hline Pakistan & 13.0 & 13.0 & 13.0 & 13.0 & 0.0 \\
\hline China & 0.0 & 0.0 & 0.0 & 0.0 & 0.0 \\
\hline India & 7.0 & 7.5 & 8.0 & 0.0 & 0.0 \\
\hline Kyrgyz Republic & 2.0 & 1.7 & 1.4 & 1.1 & 0.8 \\
\hline Iran & 0.8 & 3.9 & 3.9 & 3.9 & 3.9 \\
\hline Belarus & 0.0 & 0.0 & 0.0 & 0.6 & 0.6 \\
\hline Kuwait Fund & 0.0 & 0.7 & 1.4 & 4.7 & 10.9 \\
\hline Saudi Fund & 0.0 & 0.0 & 0.0 & 1.4 & 7.0 \\
\hline Multilateral & 363.5 & 369.4 & 405.8 & 459.6 & 551.6 \\
\hline IMF & 110.8 & 110.2 & 92.0 & 99.8 & 115.5 \\
\hline European Union & 73.3 & 45.8 & 52.3 & 47.8 & 44.4 \\
\hline World Bank & 146.3 & 171.9 & 206.5 & 226.4 & 277.9 \\
\hline Islamic Development Bank & 8.3 & 11.4 & 16.2 & 25.3 & 34.6 \\
\hline Asian Development Bank & 21.6 & 25.1 & 33.4 & 53.2 & 70.1 \\
\hline OPEC Fund & 3.1 & 5.0 & 5.4 & 7.1 & 9.1 \\
\hline Commercial credits $1 /$ & 331.0 & 117.4 & 119.3 & 103.4 & 57.6 \\
\hline Government guaranteed & 22.3 & 60.2 & 53.0 & 63.2 & 25.1 \\
\hline \multirow[t]{2}{*}{ Non-guaranteed } & 308.7 & 57.2 & 66.3 & 40.3 & 32.5 \\
\hline & \multicolumn{5}{|c|}{ (In percent of total debt) } \\
\hline Bilateral & 43.4 & 52.1 & 48.0 & 45.4 & 25.9 \\
\hline Multilateral & 29.6 & 36.3 & 40.2 & 44.6 & 67.1 \\
\hline \multirow[t]{2}{*}{ Commercial credits } & 27.0 & 11.5 & 11.8 & 10.0 & 7.0 \\
\hline & \multicolumn{5}{|c|}{ (In percent of GDP) } \\
\hline Total debt & 128.3 & 98.4 & 84.6 & 66.3 & 39.7 \\
\hline Bilateral & 55.7 & 51.3 & 40.6 & 30.1 & 10.3 \\
\hline Multilateral & 38.0 & 35.7 & 34.0 & 29.5 & 26.6 \\
\hline \multirow[t]{2}{*}{ Commercial credits } & 34.6 & 11.4 & 10.0 & 6.6 & 2.8 \\
\hline & \multicolumn{5}{|c|}{ (In percent of exports) 2/ } \\
\hline Total debt & 271.5 & 217.5 & 204.3 & 168.4 & 120.4 \\
\hline Bilateral & 117.7 & 113.4 & 98.1 & 76.4 & 31.2 \\
\hline Multilateral & 80.4 & 79.0 & 82.1 & 75.1 & 80.8 \\
\hline Commercial credits & 73.3 & 25.1 & 24.1 & 16.9 & 8.4 \\
\hline
\end{tabular}

Sources: Tajik authorities; and Fund staff estimates.

$1 /$ Credits to public enterprises in Tajikistan.

2/ Exports of goods and services, excluding barter trade in alumina and electricity. 
Table A-33. Tajikistan: Public Sector External Debt Service, 2000-04

\begin{tabular}{|c|c|c|c|c|c|}
\hline & 2000 & 2001 & 2002 & 2003 & $\begin{array}{r}\text { Est. } \\
2004\end{array}$ \\
\hline & \multicolumn{5}{|c|}{ (In millions of U.S. dollars) } \\
\hline Total debt service & 43.2 & 53.7 & 67.0 & 58.7 & 70.7 \\
\hline Russia & 8.8 & 9.1 & 6.5 & 12.2 & 6.1 \\
\hline United States & 2.0 & 0.7 & 1.6 & 1.6 & 1.6 \\
\hline Turkey & 0.7 & 2.7 & 2.7 & 3.1 & 3.0 \\
\hline Uzbekistan & 12.7 & 0.0 & 13.0 & 11.6 & 1.2 \\
\hline IMF & 11.7 & 13.5 & 35.3 & 14.3 & 12.4 \\
\hline World Bank & 0.4 & 0.4 & 1.3 & 1.8 & 2.2 \\
\hline Other & 6.9 & 27.3 & 6.5 & 14.1 & 44.2 \\
\hline Interest & 15.0 & 15.2 & 14.0 & 21.5 & 14.0 \\
\hline Russia & 8.8 & 9.1 & 6.5 & 12.2 & 6.1 \\
\hline United States & 0.7 & 0.7 & 0.6 & 0.6 & 0.6 \\
\hline Turkey & 0.7 & 0.2 & 0.1 & 0.6 & 0.5 \\
\hline Uzbekistan & 1.1 & 0.0 & 0.3 & 1.2 & 1.2 \\
\hline IMF & 1.8 & 1.6 & 0.7 & 0.5 & 0.6 \\
\hline World Bank & 0.4 & 0.4 & 1.3 & 1.8 & 2.2 \\
\hline Other & 1.5 & 3.3 & 4.4 & 4.7 & 2.8 \\
\hline Principal & 28.2 & 38.5 & 53.0 & 37.3 & 57.0 \\
\hline Russia & 0.0 & 0.0 & 0.0 & 0.0 & 0.0 \\
\hline United States & 1.3 & 0.0 & 1.0 & 1.0 & 1.0 \\
\hline Turkey & 0.0 & 2.6 & 2.6 & 2.6 & 2.6 \\
\hline Uzbekistan & 11.6 & 0.0 & 12.8 & 10.5 & 0.0 \\
\hline IMF & 9.9 & 11.9 & 34.6 & 13.8 & 11.8 \\
\hline World Bank & 0 & 0 & 0 & 0 & 0 \\
\hline \multirow[t]{2}{*}{ Other } & 5.4 & 24.0 & 2.1 & 9.4 & 41.7 \\
\hline & \multicolumn{5}{|c|}{ (In percent of GDP) } \\
\hline Total debt service & 4.5 & 5.2 & 5.6 & 3.8 & 3.4 \\
\hline Interest & 1.6 & 1.5 & 1.2 & 1.4 & 0.7 \\
\hline \multirow[t]{2}{*}{ Principal } & 3.0 & 3.7 & 4.4 & 2.4 & 2.7 \\
\hline & \multicolumn{5}{|c|}{ (In percent of relevant exports) } \\
\hline Total debt service & 9.6 & 11.5 & 13.6 & 9.6 & 10.4 \\
\hline Interest & 3.3 & 3.2 & 2.8 & 3.5 & 2.0 \\
\hline Principal & 6.2 & 8.2 & 10.7 & 6.1 & 8.3 \\
\hline
\end{tabular}

Sources: Tajik authorities; and Fund staff estimates. 
Table A-34. Tajikistan: Exchange Rates and U.S. Dollar Wages, 2000-04

\begin{tabular}{|c|c|c|c|c|c|c|c|c|c|}
\hline & \multirow{3}{*}{$\begin{array}{l}\text { Somoni } \\
\text { per } \\
\text { U.S. dollar }\end{array}$} & \multicolumn{3}{|c|}{ Nominal Exchange Rate Indices 1/ $2 /$} & \multicolumn{3}{|c|}{ Real Exchange Rate Indices 1/ 2/ } & \multirow{2}{*}{\multicolumn{2}{|c|}{$\begin{array}{l}\text { Average Monthly } \\
\text { Wages (in US\$) }\end{array}$}} \\
\hline & & Average & U.S. & Russian & Average & U.S. & $\overline{\text { Russian }}$ & & \\
\hline & & & dollar & ruble & & dollar & ruble & Tajikistan & Russia \\
\hline 2000 & 1,740 & 7.4 & 2.8 & 15.5 & 195 & 161 & 195 & 9 & 110 \\
\hline January & 1,550 & 8.6 & 3.4 & 18.7 & 198 & 164 & 211 & 9 & 88 \\
\hline February & 1,592 & 8.4 & 3.2 & 18.1 & 192 & 157 & 204 & 9 & 88 \\
\hline March & 1,631 & 8.1 & 3.1 & 17.4 & 190 & 155 & 199 & 10 & 99 \\
\hline April & 1,637 & 8.1 & 3.1 & 17.3 & 196 & 159 & 204 & 9 & 99 \\
\hline May & 1,661 & 8.1 & 3.0 & 16.9 & 204 & 165 & 206 & 9 & 101 \\
\hline June & 1,681 & 7.8 & 2.9 & 16.4 & 197 & 163 & 199 & 9 & 108 \\
\hline July & 1,900 & 7.1 & 2.7 & 14.7 & 177 & 148 & 176 & 8 & 114 \\
\hline August & 1,958 & 6.9 & 2.6 & 14.1 & 181 & 151 & 177 & 8 & 115 \\
\hline September & 2,050 & 6.8 & 2.5 & 13.8 & 191 & 158 & 183 & 10 & 119 \\
\hline October & 2,200 & 6.6 & 2.4 & 13.3 & 206 & 170 & 194 & 9 & 122 \\
\hline November & 2.20 & 6.2 & 2.3 & 12.5 & 207 & 172 & 194 & 7 & 124 \\
\hline December & 2.20 & 6.1 & 2.3 & 12.6 & 202 & 171 & 191 & 10 & 144 \\
\hline 2001 & 2.38 & 5.9 & 2.1 & 12.1 & 194 & 167 & 177 & 10 & 152 \\
\hline January & 2.28 & 5.9 & 2.2 & 12.3 & 195 & 168 & 186 & 9 & 131 \\
\hline February & 2.35 & 5.8 & 2.1 & 12.0 & 191 & 165 & 180 & 9 & 127 \\
\hline March & 2.35 & 5.8 & 2.1 & 12.1 & 194 & 167 & 179 & 9 & 144 \\
\hline April & 2.35 & 5.9 & 2.1 & 12.1 & 198 & 170 & 181 & 8 & 139 \\
\hline May & 2.35 & 5.9 & 2.1 & 12.2 & 201 & 172 & 182 & 9 & 143 \\
\hline June & 2.35 & 6.0 & 2.1 & 12.3 & 200 & 171 & 179 & 10 & 151 \\
\hline July & 2.35 & 6.0 & 2.1 & 12.3 & 200 & 171 & 178 & 10 & 155 \\
\hline August & 2.38 & 5.8 & 2.1 & 12.1 & 191 & 165 & 174 & 10 & 159 \\
\hline September & 2.40 & 5.8 & 2.1 & 12.1 & 189 & 164 & 172 & 14 & 157 \\
\hline October & 2.40 & 5.9 & 2.1 & 12.2 & 191 & 166 & 173 & 11 & 162 \\
\hline November & 2.46 & 5.8 & 2.0 & 12.0 & 190 & 165 & 171 & 11 & 166 \\
\hline December & 2.51 & 5.7 & 2.0 & 11.8 & 189 & 165 & 170 & 13 & 189 \\
\hline 2002 & & 5.2 & 1.8 & 11.3 & 176 & 160 & 160 & 12 & 180 \\
\hline January & 2.55 & 5.6 & 2.0 & 11.8 & 188 & 166 & 168 & 10 & 156 \\
\hline February & 2.65 & 5.6 & 1.9 & 11.7 & 187 & 164 & 166 & 11 & 155 \\
\hline March & 2.68 & 5.4 & 1.9 & 11.5 & 182 & 160 & 162 & 12 & 168 \\
\hline April & 2.68 & 5.4 & 1.9 & 11.5 & 185 & 163 & 165 & 11 & 170 \\
\hline May & 2.70 & 5.3 & 1.9 & 11.5 & 181 & 163 & 162 & 11 & 170 \\
\hline June & 2.70 & 5.2 & 1.9 & 11.5 & 177 & 161 & 161 & 12 & 176 \\
\hline July & 2.71 & 5.2 & 1.8 & 11.5 & 175 & 162 & 161 & 11 & 186 \\
\hline August & 2.79 & 5.1 & 1.8 & 11.3 & 173 & 158 & 158 & 11 & 192 \\
\hline September & 2.92 & 4.9 & 1.7 & 10.9 & 172 & 157 & 157 & 13 & 185 \\
\hline October & 2.95 & 4.8 & 1.7 & 10.6 & 167 & 153 & 152 & 13 & 188 \\
\hline November & 2.95 & 4.8 & 1.7 & 10.7 & 165 & 153 & 151 & 14 & 191 \\
\hline December & 3.00 & 4.7 & 1.7 & 10.5 & 165 & 155 & 151 & 15 & 222 \\
\hline 2003 & 3.04 & 4.3 & 1.6 & 9.9 & 160 & 164 & 144 & 15 & 233 \\
\hline January & 3.07 & 4.6 & 1.7 & 10.5 & 166 & 160 & 152 & 12 & 189 \\
\hline February & 3.08 & 4.5 & 1.6 & 10.2 & 162 & 158 & 148 & 13 & 195 \\
\hline March & 3.09 & 4.4 & 1.6 & 10.1 & 164 & 161 & 149 & 13 & 204 \\
\hline April & 3.09 & 4.4 & 1.6 & 10.0 & 165 & 164 & 148 & 13 & 214 \\
\hline May & 3.09 & 4.3 & 1.6 & 9.9 & 158 & 163 & 144 & 13 & 216 \\
\hline June & 3.09 & 4.2 & 1.6 & 9.8 & 155 & 162 & 140 & 14 & 229 \\
\hline July & 3.09 & 4.2 & 1.6 & 9.7 & 155 & 160 & 138 & 14 & 242 \\
\hline August & 3.09 & 4.3 & 1.6 & 9.7 & 155 & 159 & 138 & 13 & 247 \\
\hline September & 3.05 & 4.3 & 1.6 & 9.8 & 157 & 161 & 140 & 17 & 241 \\
\hline October & 2.99 & 4.2 & 1.6 & 9.7 & 159 & 168 & 143 & 20 & 248 \\
\hline November & 2.96 & 4.3 & 1.7 & 9.8 & 162 & 172 & 143 & 19 & 263 \\
\hline December & 2.93 & 4.2 & 1.7 & 9.8 & 160 & 175 & 143 & 22 & 306 \\
\hline 2004 & 2.90 & 4.2 & 1.7 & 9.6 & 156 & 176 & 135 & 21 & 290 \\
\hline January & 2.91 & 4.2 & 1.7 & 9.7 & 158 & 177 & 140 & 19 & 258 \\
\hline February & 2.91 & 4.2 & 1.7 & 9.7 & 158 & 179 & 139 & 18 & 274 \\
\hline March & 2.92 & 4.3 & 1.7 & 9.7 & 159 & 178 & 138 & 21 & 285 \\
\hline April & 2.98 & 4.3 & 1.7 & 9.7 & 160 & 178 & 137 & 18 & 289 \\
\hline May & 3.00 & 4.3 & 1.7 & 9.8 & 160 & 177 & 137 & 19 & 285 \\
\hline June & 3.02 & 4.3 & 1.7 & 9.7 & 156 & 174 & 135 & 20 & 301 \\
\hline July & 3.03 & 4.2 & 1.7 & 9.6 & 154 & 174 & 133 & 19 & 305 \\
\hline August & 3.02 & 4.2 & 1.7 & 9.6 & 154 & 173 & 133 & 19 & 315 \\
\hline September & 3.03 & 4.1 & 1.7 & 9.6 & 156 & 175 & 134 & 24 & 304 \\
\hline October & 3.02 & 4.1 & 1.7 & 9.5 & 155 & 176 & 134 & 25 & 304 \\
\hline November & 3.03 & 4.0 & 1.7 & 9.3 & 151 & 175 & 129 & 24 & 246 \\
\hline December & 3.04 & 3.9 & 1.6 & 9.1 & 145 & 175 & 126 & 27 & 313 \\
\hline
\end{tabular}

1/ May 1995=100. Using period average exchange rates. The real exchange rate indices and average nominal exchange rate index are based on INS data. An increase denotes appreciation. 